\title{
$\Pi \mathrm{AI} \Delta \mathrm{EIA}$
}

PA IDE I A

(pie-dee-ah)

VOLUME 3, 2016

\section{CAL POLY}

Political Science Department

College of Liberal Arts
PI SIGMA ALPHA

OMICRON GAMMA

CHAPTER 


\title{
PAIDEIA \\ JOURNAL OF POLITICAL SCIENCE
}

\author{
Volume 3 \\ Spring 2016 \\ Pi Sigma Alpha \\ Omicron Gamma Chapter \\ California Polytechnic State University \\ San Luis Obispo
}


California Polytechnic State University, San Luis Obispo

Published in the United States of America

by the Cal Poly Political Science Department

1 Grand Avenue, Building 47, Office 14

San Luis Obispo, CA 93407

http://politicalscience.calpoly.edu/

Copyright (C) California Polytechnic State University, San Luis Obispo

Cover art copyright (C) Annie Priestley, Monique Martinez

Photographs copyright (C) Katherine Spade, Michael Zamora, Anelise Powers, Anika Leithner, Emily Matthews, Emilio Horner, Megan Humphries, Michael Dyar, Mike Hurdelbrink, Phillip Kibbey, Caitlyn Morrison, Danielle Veatch, Emily Guant, Ginger Jacobs, James Weber, Kayvan Chinichian, Kevin Deely, Kristen Henry, Kyle Libby, Lauren Lindsay, Lindsay Constantino, Luisa Tembo, Michelle Cristobal, Stephen Richardson, Troy Gabriel, and Nesrine Majzoub, Christina Barton

Neither the editors nor Cal Poly assume responsibility for statements of fact or opinion made by the contributors.

All Rights Reserved. Except in those cases which comply with the fair use guidelines U.S. copyright law (U.S.C Title 17), no part of this publication may be reproduced, stored in a retrieval system, or transmitted in any form by any means, electronic, mechanical, or otherwise, without the prior permission from the publisher. 


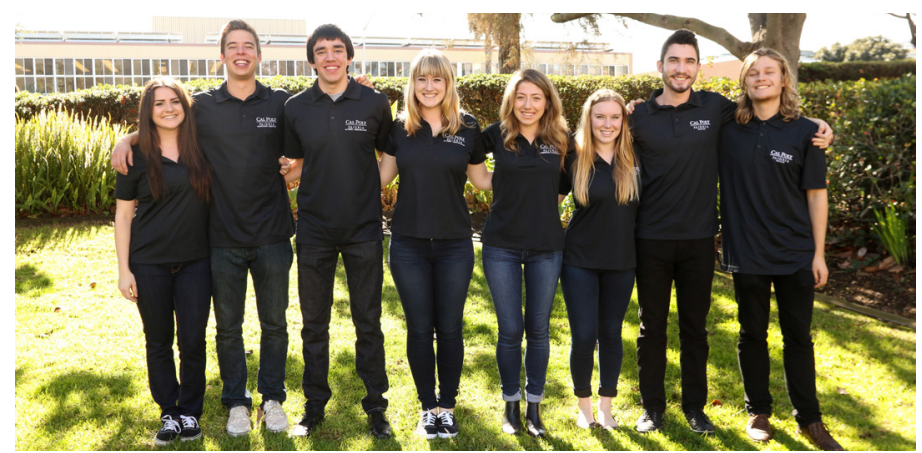

We are delighted to introduce you to the third volume of Paideia, a proud representation of past and present students' success. Student-authored academic papers provide just a taste of the vast amount of knowledge Cal Poly's Political Science students have. Meanwhile, alumni spotlights provide a great representation of all the different career paths present students can embark on.

This third edition represents the continuation of last year's goal of maintaining Paideia as a tradition that all future Cal Poly students can have access to. This year's volume has made monumental steps forward in reaching new prestige for the journal. At the end of this year, Paideia can be accessed online through the Digital Commons database. This allows students' academic papers to be accessed around the globe and be used in other researchers' work.

It is our hope that throughout this journal you will find yourself looking at topics with a new perspective. In a continuously progressing world, it is our desire that this journal brings you at least one step closer to learning something you did not know before.

We invite you to pioneer through this journal and step into just a little piece of the Political Science department's outlooks and experiences that have shaped this year's third volume of Paideia.

Katherine Spade

Executive Editor 

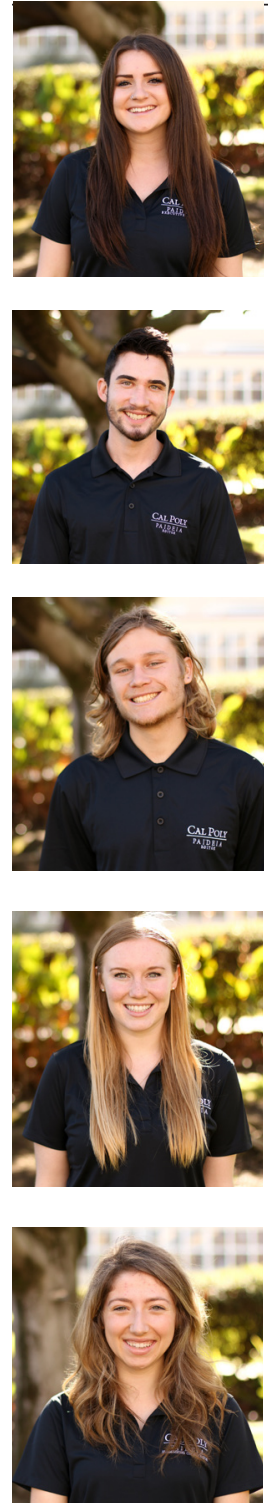

Executive Editor

Katherine Spade

Political Science BA

Global Politics Concentration

Class of 2016

\section{Editor}

Michael Zamora

Political Science BA

Pre-Law Concentration

Class of 2016

\section{Editor}

Emilio Horner

Political Science BA

Women and Gender Studies Minor

Class of 2016

\section{Editor}

Emily Matthews

Political Science BA

Global Politics Concentration

Environmental Studies Minor

Class of 2017

\section{Submissions Coordinator}

Anelise Powers

Political Science BA

Pre-Law Concentration

Class of 2017 


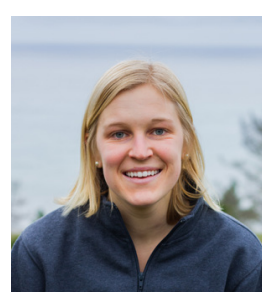

Graphic Designer

Christina Barton

Graphic Communication

Design Reproduction and Technology Concentration

Photography Minor

Class of 2016

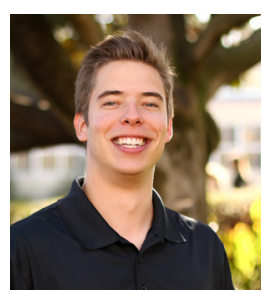

Marketing Director

Mike Hurdelbrink

Business Administration BA

Information Systems Concentration

Class of 2016

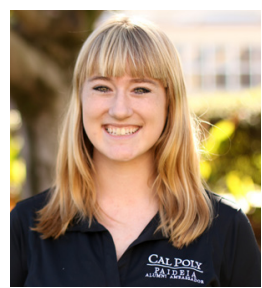

Alumni Ambassador

Megan Humphries

Political Science BA

Pre-Law Concentration

Class of 2017

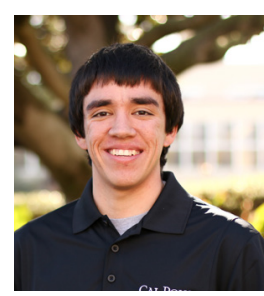

Alumni Ambassador

Michael Dyar

Political Science BA

Global Politics Concentration

Class of 2017

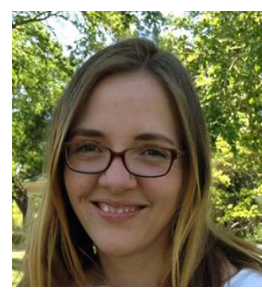

Faculty Advisor

Dr. Anika Leithner

Political Science Professor 
FRONT MATTER

III | Editor's Note

IV, V | The Paideia Team

\section{ARTICLES}

10 | The Human Rights Perspective Behind Patent Laws | Caitlyn Morrison

28 | Alumni Spotlight | James Weber, Economic Diversification Advisory Consultant

32 | Age of Putin: Global Implications of Russia's Domestic Policy | Stephen Richardson

46 | Alumni Spotlight | Kayvan Chinichian, Associate Director of Individual Membership at the Atlantic Council

50 New and Changing Implications of Exploring the Final Frontier: What Does U.S. Dominance Signify For Global Politics? | Emily Gaunt

66 | Will of the People: Public Opinion and U.S. Foreign Policy | Troy Gabriel

84 | Alumni Spotlight | Lauren Lindsay, Associate at Quinn Emanuel Urquhart \& Sullivan, LLP

88 | Briefing Memo: Sex Trafficking | Danielle Veatch

98 | Examining Corporate Power at Home and Abroad | Ginger Jacobs 
118 | Alumni Spotlight | Michelle Cristobal, Financial Analyst for the Mozilla Corporation

122 | Punishing Criminal Attempts: The Role of Harm in Criminal Sentencing | Kevin Deely

144 | National Development and Indigenous Peoples Land Rights | Luisa Tembo

156 | Alumni Spotlight | Lindsey Constantino, Contractor for the U.S Department of Transportation

160 An Examination of the Debate Surrounding Core Curriculum State Standards in American Education Reform | Kristen Henry

168 | Alumni Spotlight | Philip Kibbey, Financial Disclosure Specialist at U.S. Senate Select Committee on Ethics

172 | Comparative Policing: A Brief Analysis of Casual Factors On Crime Rates and Law Enforcement in China, Mexico, and Russia | Kyle Libby

BACK MATTER

180 | Acknowledgements 


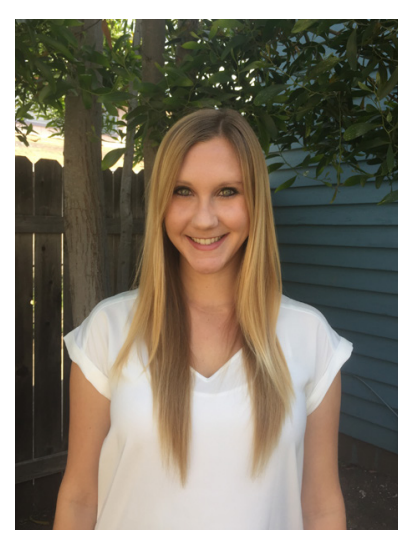

CAITLYN MORRISON is an undergraduate senior studying Political Science with an independent concentration centralized in Public Policy. Academically, she is primarily interested in international relations, specifically in Chinese politics and social policies on homelessness and poverty. Caitlyn's inspiration for this paper came from two case studies she encountered in lecture, which followed two women's personal struggles to afford patented healthcare testing with no ability alternative. This illustration struck Caitlyn as an obvious and outright human rights violation, bringing her to examine how access to medicine and treatment are viewed through a human rights perspective in the international realm. After she graduates, Caitlyn aims to pursue a career in public policy and public affairs in Washington D.C. 
THE HUMAN RIGHTS PERSPECTIVE BEHIND PATENT LAWS Caitlyn Morrison

\begin{abstract}
The reasons for the lack of access to essential healthcare policies and medicines are manifold, but in many cases the high prices of drugs create a barrier to needed treatments in developing countries. ${ }^{1}$ These prohibitive drug prices are often the result of corporations in industrialized nations holding patents on the technology to produce their recently discovered medicine. Strong intellectual property rights were developed for pharmaceutical companies who invested in the creation of new medicines to receive the maximum profit from their innovation. However, the monopolization of these medicines' production gives the corporation the ability to sell their product at a high cost, often unreachable for poor countries to afford. Governments in these developing countries have attempted to bring down the prices of medicines yet been blocked by industrialized countries who formulated the World Trade Organization Trade-Related Aspects of Intellectual Property Rights (TRIPS) Agreement to set strong standards for the protection of intellectual property,
\end{abstract}

${ }^{1}$ Ellen Hoen, "TRIPS, Pharmaceutical Patents and Access to Essential Medicines: Seattle, Doha and Beyond," Chicago Journal for International Law, Vol. 3, no 1 (Spring 2002). 
including patents for pharmaceuticals. ${ }^{2}$ In addition, patents on genes, such as the case of Myriad Genetics' ownership of the BRCA1 and BRCA2 genes restrict diagnostics, therapies, drug development and identification of related cancers to be done solely by Myriad preventing patients from obtaining a second diagnostic opinion from an independent laboratory. Article 25 in the Universal Declaration of Human Rights states that "everyone has the right to a standard of living adequate for the health and well-being of himself and his family including medical care and the right to security in the event of sickness and disability." ${ }^{3}$ Therefore denying individuals access to available lifesaving medicine for the sake of maximizing corporations profit is causing citizens in developing countries to suffer from a lack of adequate standard of health. To understand why patent laws have been predominantly looked at as a political economy issue and remain disproportionately unexamined under the human rights scope leads me to ask the following research question: Why are human rights laws not being applied to the restrictions imposed by global patent law?

\section{Real-World Observation}

On April 27, 2015 the Royal Society of Medicine held a conference in London and produced a report stating that five billion people do not have access to safe, affordable surgical and anesthesia care when needed. ${ }^{4}$ Access is the worst in low-income and lower-middle-income countries, where nine of ten people cannot access basic surgical care. ${ }^{5}$ This conference was held to examine how global surgery will be shaped in the future, publishing their findings in The Lancet journal in order to educate developed countries on the role they ought to play to help combat this issue. ${ }^{6}$ Their research stated that progress in global health over the past 25 years has not been uniform internationally with mortality and morbidity from common conditions

\footnotetext{
${ }^{2}$ Ibid.

3 The United Nations, Universal Declaration of Human Rights. 1948

${ }^{4}$ Donald Mcneil, "Routine Operations Could Save Millions of Lives, If They Were Available," The New York Times, April 27, 2015.

${ }^{5}$ Meara John, "Global Surgery 2030: Evidence and Solutions for Achieving Health, Welfare, and Economic Development." The Lancet, 386.9993 (2015): 569-624.

6 "Global Surgery, Anesthesia, and Obstetrics: Shifting Paradigms and Challenging Generations," The Royal Society of Medicine, 2015.
} 
needing surgery growing in the world's poorest regions. ${ }^{7}$ In the absence of surgical care, fatality rates are high for common, easily treatable conditions including appendicitis, hernia, fractures, obstructed labor, congenital anomalies, and breast and cervical cancer.

Low and middle income countries are facing the burden of infectious disease, maternal disease, non-communicable diseases, and injuries all of which surgical and an anesthesia care are essential for treatment. When viewing the large projected increase in the incidence of cancer, road traffic injuries and cardiovascular diseases in these low and middle income countries, the need for surgical services in these regions will continue to rise substantially from now until 2030. ${ }^{8}$ Despite the growing need, surgery was considered too complicated and expensive to be an integral part of public health in developing countries. Therefore, the Royal Society of Medicine decided to bring light to this issue. The World Bank estimates that universal access to 44 procedures would prevent $6 \%$ to $7 \%$ of all preventable deaths in low and middle income countries. ${ }^{9}$ With surgeries new found recognition as a cost effective public health intervention, providing access to essential surgical services and safe and timely medical care can only be achieved by addressing the weaknesses within the health care system.

The reasons for the lack of access to essential healthcare policies and medicines are manifold, but in many cases the high prices of drugs create a barrier to needed treatments in developing countries. ${ }^{10}$ These prohibitive drug prices are often the result of corporations in industrialized nations holding patents on the technology to produce their recently discovered medicine. Strong intellectual property rights were developed for pharmaceutical companies who invested in the creation of new medicines to receive the maximum profit from their innovation. However, the monopolization of medicines' production affords corporations with the ability to sell their product at a high cost, often unreachable for poor countries to afford. Governments in

\footnotetext{
${ }^{7}$ Op. Cit., fn. 5

${ }^{8}$ Op. Cit., fn. 5

9 The World Bank, "Surgery Could Save Millions of Lives in Developing Countries," March 26, 2015.

${ }^{10}$ Ellen Hoen, "TRIPS, Pharmaceutical Patents and Access to Essential Medicines: Seattle, Doha and Beyond," Chicago Journal for International Law, Vol. 3, no 1 (Spring 2002).
} 
these developing countries have attempted to bring these prices down, yet have been blocked by industrialized countries who formulated the World Trade Organization Trade-Related Aspects of Intellectual Property Rights (TRIPS) Agreement, which set strong standards for the protection of intellectual property, including patents for pharmaceuticals. ${ }^{11}$ Article 25 in the Universal Declaration of Human Rights states that "everyone has the right to a standard of living adequate for the health and well-being of himself and his family including medical care and the right to security in the event of sickness and disability." 12 Therefore, denying individuals access to available lifesaving medicine for the sake of maximizing corporations profit is causing citizens in developing countries to suffer from a lack of adequate standard of health. To understand why patent laws have been predominantly looked at as a political economy issue and remain disproportionately unexamined under the human rights scope leads me to ask the following research question: Why are human rights laws not being applied to the restrictions imposed by global patent law?

\section{Conventional Wisdom}

International conventional wisdom arrives at the same consensus, that people believe human rights should be a higher priority on the international agenda. This consensus is displayed through the non-partisan poll conducted by World Public Opinion, which states that majorities in all nations surveyed express support for the United Nations playing an active role in promoting human rights and reject the argument that their intervention would be an improper interference in the internal affairs of a country. ${ }^{13}$ Publics in most countries favor the UN playing a larger role than it presently does to promote human rights. In a second World Public Opinion survey, data suggests that a majority of individuals in 17 of the 21 nations polled say their government should abide by international law and reject the view that governments are not obliged to follow international laws when they conflict with the national

\footnotetext{
${ }^{11}$ Ibid.

12 The United Nations, Universal Declaration of Human Rights. 1948.

13 “Polls Find Strong International Consensus on Human Rights," World Public Opinion, December 7, 2010.
} 
interest. ${ }^{14}$ This data proves an authoritative claim that the international community supports human rights laws as an international movement.

However, current practices suggest that patent laws are restricting human rights through infringing on an individual's right to health as stated in the Universal Declaration of Human Rights. Patents allow for monopolistic control over substances that are essential to research, medicine and patients - all things crucial in human rights plans. ${ }^{15}$ The last decade has seen a dramatic expansion of intellectual property protection standards, both in their subject matter and scope of economic interests they protect. Due to the TRIPS agreement, intellectual property rights have been an economic issue in the world trading system with unexamined implications in a public health, education, or human rights sectors. ${ }^{16}$ The surge of the human rights movement during post-World War II placed international patent law interests in the shadows while other issues emerged to the movement's forefront, leaving them relatively unexplored. This paper brings light to pharmaceutical patent laws under the scope of international human rights to identify the restrictions imposed by these intellectual property interests and the global implications they create.

\section{Methodology and Evidence}

To illustrate the impact of patent laws on the field of international human rights, this paper will use qualitative methodology in the form of case study research. These case studies will examine two specific restrictions imposed by patent laws: access to medicine and access to healthcare. This paper will mostly utilize primary sources in order to obtain non-bias evidence to support my research findings. Examples of primary sources that will be included in this paper will be government reports, United Nations' reports, World Bank reports and World Health Organization reports. My secondary evidence will be drawn from sources including the New York Times, The Washington Post and scholarly journals.

\footnotetext{
14 "People in 17 of 21 Nations Say Governments Should Put International Law Ahead of National Interest," World Public Opinion, November 2, 2009.

15 Daniel Kevles, “Can They Patent Your Genes?,” The New York Review, March 7, 2013.

${ }^{16}$ Laurence Helfer, "Toward a Human Rights Framework for Intellectual Property," UC

Davis L. Rev, Vol. 40 (2006): 975.
} 


\section{Theoretical Paradigm}

The theory that best explains and frames my research question is international legal realism. In international law, legal realism's core assumption is that rules and law that govern interstate behavior are based on the distribution of power between states. ${ }^{17}$ This paradigm emphasizes that world politics are driven by the relative power positions of states and the laws they create. ${ }^{18}$ According to the theory's founder Hans Morgenthau, "universal moral principles cannot be applied to the actions of states in their abstract universal formulation, but they must be filtered through the concrete circumstances of time and place." ${ }^{19}$ This analysis of the relationship between legal realism and ethics explains that realists are aware of the moral significance of political action but are also aware of the tension between morality and the requirements of successful political action. Morgenthau introduces rationality to this theory defining rationality as a process of calculating the costs and benefits of all alternative policies in order to determine their utility and ability to maximize power.

Given these assumptions, international legal realism will help explain my research question and research findings. The primary assumption of international legal realism being that politics are driven by the relative power of states frames the dynamic of developed nations' power over developing nations in creating international patent laws. Realism's assumption of states political power as the driving force for all outcomes in world politics helps to frame this papers examination of states laws effect on international human rights. The theory's aspect of rationality helps to examine international patent law as a political economy issue due to its innate relation to cost-benefit analysis.

Conventional wisdom thinkers use the theoretical paradigm of liberalism to frame and explain their opinion on human rights issues and international intervention. The fundamental principle of liberalism is that special interests rather than state interests prevail and that peace and cooperation are in the best interest of every state. ${ }^{20}$ The founders of liberalism, Immanuel Kant and

\footnotetext{
17 Professor Shelley L. Hurt, “Theoretical Paradigms of International Law,” POLS 426-01 course reader (Spring 2015).

18 Ibid.

19 Julian Korab-Karpowicz, "Political Realism in International Relations", The Stanford

Encyclopedia of Philosophy (Summer 2013 Edition), Edward N. Zalta (ed.).

${ }^{20}$ Op. Cit., fn. 16
} 
Adam Smith, emphasize the importance of interdependence of states and non-state actors in implementing international institutions and reform. ${ }^{21}$ This theory explains the conventional wisdoms rational of believing that human rights should be put before the states own interest. The theory's belief in interdependence between states frames these thinkers' desire for increased action for human rights and United Nations intervention. Liberalism helps explain an ideal way of handling human rights issues while international legal realism frames the actual situation occurring due to the restrictions imposed by patent laws.

\section{Restrictions Imposed: Access to Medicine}

The Office of the United Nations High Commissioner for Human Rights convened an expert conference on October 11, 2010 in Geneva, Switzerland to "exchange views on human rights considerations relating to the realization of access to medicines as one of the fundamental elements in achieving the full realization of the right of everyone to the highest attainable standard of physical and mental health." 22 During this conference Craig Mokhiber, speaking on behalf of the UN Human Rights office, stated that "human rights law provides standards for access to medicine requiring that they are safe, affordable, of appropriate quality, and made available without discrimination." ${ }^{23}$ He listed a number of steps that could be taken to achieve health as a fundamental human right including expanding access to off-patent drugs and price control.

The acknowledgement of patent protections as impeding access to medicine and therefore human rights standards is a central issue initially imposed by the 1994 TRIPS agreement. The agreement states that all World Trade Organization (WTO) member states are obliged to grant patents to medical inventions to encourage innovation by assuring compensation to

\footnotetext{
${ }^{21}$ Juliet Kaarbo and James Ray, Global Politics (Boston: Cengage Learning, 2010).

22 United Nations Human Rights Council, "Promotion and Protection of All Human Rights, Civil Political, Economic, Social and Cultural Rights, Including the Right to Development," 12th Session. October 12, 2009.

${ }^{23}$ United Nations Human Rights, "Access to Medicines - Fundamental to the Right to Health," November 5, 2010.
} 
recoup the high cost of developing new medicines. ${ }^{24}$ These patents on medicines give drug companies the right to prevent others from manufacturing their innovation, meaning that only brand name drugs are available for 20 years from the filing date. Therefore during these 20 years, artificially high prices can be charged. ${ }^{25}$ Some developing countries have viewed the TRIPS agreement as a barrier in their attempt to combat public health problems by restricting drug availability due to high cost of unaffordable medicine in countries whose health-care systems are often overwhelmed by HIV/AIDS and other infectious diseases. ${ }^{26}$ Without patent protection, the production of generic drugs drives the prices of medicines down to affordable levels. For example, Prozac which during its patent period sold for $\$ 2.50$ per pill was produced by a generic manufacturer for only $\$ 0.25$ a pill after its patent ended. ${ }^{27}$ This large increase in the price of medicines due to patent law has a large effect on people in developing countries who cannot afford to buy these drugs, leaving many suffering from treatable diseases. This displays the conflict between patent law and human rights due to restrictions on access to medicine through heavily increased prices, leaving millions of people in developing countries unable to achieve their right to health. The Doha Declaration was intended to be a shield for developing countries against the repercussions of universalized intellectual property standards to drug access however; pharmaceutical patents are still creating a barrier.

The Doha Declaration was a 2005 amendment to the TRIPS agreement stating that developing countries could use compulsory licenses in situations of a national emergency to access life-sustaining medicines. ${ }^{28}$ Compulsory licenses are issued by governments to authorize the use or production of a

\footnotetext{
${ }^{24}$ Ian F. Fergusson, "The WTO, Intellectual Property Rights, and the Access to Medicine Controversy," (online report, U.S. Library of Congress, Congressional Research Service, December 12, 2006).

25 Wendy H. Schacht and John R. Thomas, "Patent Law and Its Application to the Pharmaceutical Industry: An Examination of the Drug Price Competition and Patent Term Restoration Act of 1984," (online report, U.S. Library of Congress, Congressional Research Service, January 10, 2005).

${ }^{26}$ Op. Cit., fn. 22

${ }^{27}$ Barry Robson and O.K. Baek, "The Engines of Hippocrates: From the Dawn of Medicine to Medical and Pharmaceutical Information," (Wiley, 1 edition, 2009): 475.

${ }^{28}$ Op. Cit., fn. 22
} 
patented item by a domestic party other than a patent holder in cases of extreme urgency or national emergency. ${ }^{29}$ Article 31 of the agreement limits the scope and duration of a compulsory license to address the circumstances for which the license is authorized and restricts production authorized by the compulsory license to the domestic market. ${ }^{30}$ According to former European Union trade negotiator Pascal Lamy "we have solved about 10\% of the problem of access to medicines in developing countries through the WTO's action." ${ }^{31}$ Even with this amendment in place, developing nations have seldom made use of the flexibility of the TRIPS agreement. Even though a developing country with no manufacturing capability may use a compulsory license to obtain a product for a generic manufacturer in another country, the generic manufacturer in the second country may have no incentive to produce such limited quantities to poor countries. In addition, under many of the proposals the product would have to use distinguishable packaging with identifiable characteristics to avoid trade diversion to other markets. ${ }^{32}$ Under such restrictions, it is not certain that a generic producer would undertake the development and formulation costs for such a limited market. ${ }^{33}$ Thus, even though a compulsory license may be issued, the drugs may never be manufactured.

Thailand provides an excellent example of why other countries have been reluctant to utilize compulsory licensing. When the country issued a number of compulsory licenses for antiretroviral drugs by Abbott's Kaletra, the large pharmaceutical company was angered at Thailand for 'ignoring the patent system.' In response, Abbott Kaletra announced it would not be applying for license to sell seven of its newest products in Thailand. ${ }^{34}$ Thailand has since been repeatedly placed on a U.S. Trade Representative 'priority watch

\footnotetext{
${ }^{29}$ Op. Cit., fn. 22

${ }^{30}$ World Trade Organization, “Trade-Related Aspects of Intellectual Property," 2015, p. 333.

31 “WTO Drug Pact Lifts Trade Talks," Wall Street Journal, September 2, 2003.

32 Implementation of Paragraph 6 of the Doha Declaration on the TRIPS Agreement and

Public Health, Note from the Chairman, Paragraph 2(b)(ii), December 16, 2002.

33 UK Commission on Intellectual Property, "Integrating Intellectual Property and Development Policy," September 2002, p. 45-46.

34 "Abbott to Withhold New Drugs from Thailand in Retaliation for Kaletra Compulsory License," Aidsmap, March 15, 2007.
} 
list' of countries seen to be committing intellectual property piracy. ${ }^{35}$ Due to the repercussions larger developed nations have the potential to impose; compulsory licensing has had little effect on widening developing countries access to medicine.

Even with a compulsory license provision in place, patents are still placing restrictions on international access to medicine. Although patents have expired on a number of first-line AIDS drugs making them available cheaply from generic makers, patents still exist on most new and second-line medicines complicating the provision of HIV treatment. This is problematic as newer antiretroviral drugs are generally less toxic, making it easier to take and more effective at fighting HIV. ${ }^{36}$ Drugs used to combat resistance are called second-line drugs and although the number of people in need of these drugs is expected to increase, the price of second-line drugs remains on average six times higher than drugs commonly used for first-line regimens. ${ }^{37}$ One limitation of TRIPS is that the new, better drugs are only available in countries that have the capacity to cover the high cost, widening the access to treatment gap due to profit margins of large pharmaceuticals being put before public health.

In February 2009, a shipment of second-line generic antiretroviral drugs was confiscated by Dutch customs authorities. The $49 \mathrm{~kg}$ of Abacavir sulfate tablets produced by an Indian company, Aurobindo, were bound for a treatment program in Nigeria. ${ }^{38}$ The tablets were later released but the seizure highlights the tensions between the European Union's rules on intellectual property rights and World Trade Organization rules concerning the production of generic medicines.

Legal showdowns have begun to arise against the drug industry in recent years highlighting the struggle for global health equity in this patent war. This is highlighted in the 2013 landmark decision by the Indian Supreme Court whose ruling blocked global pharmaceutical giant Novaritis' effort

\footnotetext{
35 "U.S. Trade Representative Places Thailand on Priority Watch List in Annual Report," Kaiser Health News, May 1, 2007.

36 "HIV/AIDS, TRIPS and Second-Line Therapy," AVERT, 2014.

37 World Health Organization, "HIV Drug Resistance Fact Sheet," April 2011.

38 "NIGERIA: Seizure of Drug Shipments Threatens ARV Access," IRIN PlusNews, March 13, 2009.
} 
to patent an updated version of its leukemia-treating drug. ${ }^{39}$ This decision cleared the way for mass production of a much cheaper generic version to supply lifesaving medicines for much of the developing world. However, larger currently pending agreements such as the Trans-Pacific Partnership Agreement (TTP), a free trade agreement involving the U.S. and 11 other Pacific-Rim countries, contains intellectual property provisions designed to preempt trade barriers that protect access to medicine. ${ }^{40}$ If signed, the TPP would force all countries to grant additional drug patents, extending monopolies on medicines beyond 20 years which will delay lower-cost versions of these medicines from entering the market. ${ }^{41}$ According to Rohit Malpani, Director of Policy and Analysis at Doctors Without Borders Access Campaign, "the intellectual property provisions of the TPP completely undermine the Obama Administration's stated public health goals." ${ }^{\prime 2}$ In addition, this would pave the way for drug industry giants to avoid the kind of public interest challenges at issue in the Indian court. ${ }^{43}$ Today, 26 million people worldwide are still without access to proper treatment, and the World Health Organization has recently pressed wealthy donor states for a major infusion of aid for medical treatment programs to meet their right to health. ${ }^{44}$ Yet, those same programs are sliding on a collision course with powerful pharmaceutical monopolies from patents. Under the global intellectual property protections, the world's poorest patients, who line up to vaccinate their children from diseases that better-off countries eradicated generations ago, are priced out of a medical market that thrives on the desire for wealth.

\section{Restrictions Imposed: Access to Healthcare}

According to a 2005 study by the National Center for Biotechnology Information, nearly 20 percent of our approximately 23,000 human genes

\footnotetext{
39 Rama Lakshmi, "India Rejects Novartis Drug Patent," The Washington Post, April 1, 2013.

40 "TPP Trade Deal Will Be Devastating for Access to Affordable Medicines," Doctors Without Borders, January 26, 2015.

${ }^{41}$ Ibid.

${ }^{42}$ Ibid.

${ }^{43}$ Michelle Chen, "Patents Against People: How Drug Companies Price Patients out of Survival," Dissent Magazine, Fall 2013.

${ }^{44}$ Ibid.
} 
have been patented. ${ }^{45}$ One particularly famous case involves Myriad Genetics patent ownership of two genes, BRCA1 and BRCA2, whose mutations can dramatically increase a woman's chance of developing breast or ovarian cancer. ${ }^{46}$ Myriad was granted seven patents in 1997 over the sequenced BRCA1 and BRCA2 genes, associated mutations and associated diagnostic tests to detect their presence. ${ }^{47}$ These patents allowed Myriad to monopolize the diagnostic tests to look for such mutations as well as give the company a virtual lock on research and diagnostics of the BRCA1 and BRCA2 genes. Since the patent system was designed to grant certain rights to inventors in order to reward and encourage human inventiveness, existing law during this patents enactment allowed this infringement upon people's access to healthcare solely because this was being looked at as an economic issue versus an ethical issue.

In order to clarify and simplify U.S. law, the Patent Act of 1952 was created. This act states that in order to qualify for a patent, an inventor must show that their innovation is useful, novel and nonobvious and something that is a process, machine, manufacture or composition of matter ${ }^{48}$ In 1980 , the Supreme Court of the United States decision in Diamond v. Chakrabarty set an important precedent for areas of patentability by ruling that laws of nature, physical phenomena, and abstract ideas are not patentable however, "manifestations of nature" are. ${ }^{49}$ Following this ruling's guidelines, the Patent and Trademark Office (PTO) was able to begin issuing patents on three different versions of DNA isolated from the body to meet this manifestation of nature requirement. The first is "complementary DNA" or cDNA which is constructed of only the gene's base pairs which produce some of the amino acids that assemble into the body's proteins placed in the same order as they occur in the native gene omitting the other gene's base pairs. ${ }^{50}$ The other two

45 Kyle Jensen and Fiona Murray, "Intellectual Property Landscape of the Human Genome," Science 310(5746):239-240 (October 14, 2005).

46 Wendy H. Schacht and John R. Thomas, "Gene Patents: A Brief Overview of Intellectual Property Issues," (online report, U.S. Library of Congress, Congressional Research Service, July 18, 2013).

${ }^{47}$ Op. Cit., fn. 15

48 Op. Cit., fn. 46

${ }^{49}$ Diamond v. Chakrabarty, 417 U.S. 303 (1980).

50 Op. Cit., fn. 46 
patented versions of DNA comprised isolated fragments or the whole of the raw DNA in a gene. Myriad was granted patents meeting the "composition of nature" requirement due to its findings of the chemical structure of the BRCA genes as well as "method" claims covering processes for diagnosing breast cancer. ${ }^{51}$ Myriad's patents encompass every conceivable use of the three types of DNA, including diagnostics, therapies, drug development and the identification of other cancers involving either of the genes. ${ }^{52}$ However, these patents soon developed controversy over the ethical issue that Myriad's monopolization on all aspects of research and diagnostic testing interfered with the progress of science and the delivery of healthcare services.

In May 2009, the Association for Molecular Pathology (AMP) along with the American Civil Liberties Union (ACLU) and nineteen other plaintiffs filed a lawsuit against Myriad Genetics Corporation seeking to overturn the patents on DNA isolated from two human genes, BRCA 1 and BRCA 2.53 The plaintiff's lawyers approached the suit as though it were a civil rights case, reaching beyond the technicalities of patent law to emphasize the human rights issue that the patents created which enabled Myriad to infringe the rights of biomedical scientists, physicians and patients. They contended that BRCA DNA, and by implication all human DNA, should not be eligible for patents as a matter of law since patients had suffered harm from Myriad enforcing its BRCA patent in clinics and laboratories stopping others from using the genes for cancer research. ${ }^{54}$ Myriad's monopolization prevented patients from obtaining a second diagnostic opinion from an independent laboratory and enabled it to charge a list price of almost $\$ 4,000$ for a BRCA gene evaluation test, a price that many women can't afford. ${ }^{55}$ Women were forced to trust one laboratory performing a single test to secure a diagnostic and inform treatment. Additionally, limiting gene-sequence based test services

${ }^{51}$ Timothy B. Lee, "You Can't Patent Human Genes. So Why Are Genetic Testing Companies Getting Sued?" The Washington Post, July 12, 2013.

52 Op. Cit., fn. 15

53 John R. Thomas, "Mayo v. Prometheus: Implications for Patents, Biotechnology, and Personalized Medicine," (online report, U.S. Library of Congress, Congressional Research Service, November 6, 2012).

54 Op. Cit., fn. 15

55 Andrew Pollack, "After Patent Ruling, Availability of Gene Tests Could Broaden," The New York Times, June 13, 2013. 
to a single provider interferes with medical training, practice, research, the advancement of medical knowledge and enhancement of public's health. ${ }^{56}$ This was not in the public interest since no other laboratory could assess the reliability of its tests, improve upon their speed or cost reducing the quality of genetic testing. ${ }^{57}$ The effects of this patent law blocked people's ability to utilize the health care service that was developed by Myriad in the first place, leaving it unavailable to many patients and unable to be further developed by outside research.

Once the result of these patent's human rights violations against people's ability to receive health care were brought to the forefront, the court reconsidered its rational for allowing human genetics to be patented. The Department of Justice backed the plaintiff's argument by filling a friend-ofthe-court brief pointing out that DNA extracted from the body was no more patent-eligible than any of the natural elements in the periodic table that had to be separated chemically from the compounds in which they occur in the earth. ${ }^{58}$ The case was brought to the Supreme Court who decided in June 2013 that genomic DNA is ineligible for patenting under the "product of nature" doctrine holding that preexisting substances found in the wild may not be patented and that Myriad had "not created anything." 59 The court took a more favorable view of cDNA observing that it is a distinct form of DNA from which it was derived and could therefore be patented. This decision against the patenting of human genes ruled that five out of Myriad's seven patents were not eligible. Additionally, more than 8,000 genes patents have the potential to be at risk due to this decision. ${ }^{60}$ This ruling is expected to make it difficult for inventors to protect early, gene-related discoveries through the patent system. In particular, how the courts will apply this decision to other biologic products. This ruling is a win for patients now having greater access to genetic testing and benefiting from scientists ability

\footnotetext{
${ }^{56}$ Michelle K. Lee, "Guidance for Determining Subject Matter Eligibility of Claims Reciting or Involving Laws of Nature, Natural Phenomena and Natural Products," College of American Pathologists, June 22, 2014.

57 Op. Cit., fn. 51

58 Op. Cit., fn. 46

59 Ibid.

${ }^{60}$ Op. Cit., fn. 55
} 
to now engage in research on these genes without fear of being sued. ${ }^{61}$ This was the first case to examine patent laws under a human rights scope and once the restrictions that these laws created were brought to court, the court unanimously decided against the ability to patent human genetic material.

The Myriad holding will have far-reaching and long-term implications for international patent law. The United States being a global hegemon, especially in holding patent laws, means that its Supreme Court decision on the Myriad matter is likely to be a leader for other jurisdictions to follow similar standards. This decision sets the United States apart from economic rivals when it comes to rules on patenting genes. For example, the European Patent Office (EPO) grants patents for inventions related to gene sequencing as long as applicants can demonstrate the industrial application of the sequence. ${ }^{62}$ Australia, Canada and Japan have similar rules, allowing the patenting of human genes as long as they are isolated and the patent application explains how the genes are useful. ${ }^{63}$ These jurisdictional differences means that the U.S. Supreme court decision does not directly impact patents in these jurisdictions, however the ruling has already made other countries reconsider their patent standards. In 2014, a Canadian Children's Hospital of Eastern Ontario filed a court challenge with the ultimate goal of invalidating patents on human genes, the first court challenge to the country's Patent Act, which is hoping to follow the U.S. Supreme Court's case rational for striking down these patents. ${ }^{64}$ The global implications of the Myriad decision create a new revelation of viewing patent laws as having the potential to be viewed as a human rights issue which could greatly affect the way all patents are seen.

\section{So What? Research Implications}

The implications of my research findings display that there is a crucial need to re-evaluate the effects that intellectual property rights impose. The technology is available to provide developed and developing nations with access to medicines and treatments that could save millions of suffering

${ }^{61}$ Emma Barraclough, "What Myriad Means for Biotech," World Intellectual Property Organization, August 2013.

${ }^{62}$ Ibid.

${ }^{63}$ Ibid.

${ }^{64}$ Sheryl Ubelacker, "Human DNA Patents Challenged By Canadian Hospital," The Huffington Post, November 3, 2014. 
lives, yet it is unutilized to its full extent due to intellectual property laws giving corporations the right to maximize its profit. The ability to invalidate patents, as well as their human rights restrictions, when examining the effects they impose on peoples access to treatment displays that this new method of evaluation could have a large influence on what is patentable internationally. The development of a human rights framework for intellectual property can provide government officials, international jurists, and states an opportunity to influence the framework's substantive content and the procedural rules that mediate relationships between these two components.

The International Covenant on Economic, Social and Cultural Rights (ICESCR) has been a major international human rights instrument addressing the issue that patent laws should allow everyone to both "enjoy the benefits of scientific progress and its applications" and "enjoy the benefit from the protection of the moral and material interests resulting from any scientific, literary or artistic production." ${ }^{65}$ This research brings to light how patent laws are beginning to be looked at as human rights issues yet, still have a ways to go to ensure that access to health is achieved for everyone. The trend of examining the importance of human rights has been on the rise since World War II. With increased knowledge from globalization on these issues coupled with this research's implications of restrictions on health, these findings have the ability to reshape international law and increase access to the benefits of scientific innovations.

${ }^{65}$ International Covenant on Economic, Social and Cultural Rights, adopted 16 December 1966, 993 U.N.T.S. 3 (entered into force 3 January 1976), G.A. Res. 2200 (XXI), 21 U.N. GAOR Supp. (No. 16), p. 49, U.N. Doc. A/6316 (1966). 


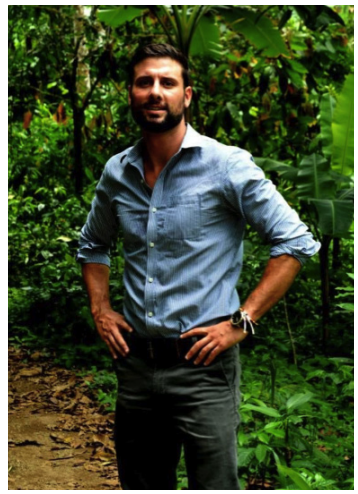

JAMES WEBER works as an advisor for firms and governments through a small private Limited Liability Company in the international development sphere. He graduated from Cal Poly in 2005 with a degree in Political Science. 


\section{ALUMNI SPOTLIGHT \\ James Weber}

Though James began his college career as a Natural Resource major, his interest in international affairs, economics, and the environment kept him engrossed in political science. In addition to political science, James kept his General Education courses centered around those that challenged him, such as business law, economics, and entrepreneurship. After graduating from Cal Poly, James attended graduate school at Notre Dame from 2008 to 2010 to earn an MBA. Not wanting to stop at an MBA, James has now decided to add another degree and will accomplish this at the University of Cambridge's International Relations program.

Currently, James works as an advisor for firms and governments through a small private Limited Liability Company (LLC) in the international development sphere. In February, James's latest project brought him to the Equatorial Guinea where he worked to analyze the economic landscape on the Bioko Island with the goal of recommending economic policy initiatives for the area. The project was successful and gave James and his team the opportunity to advise the Minister of Agriculture of their economic diversification strategy. In terms of accomplishments, James is proud of the research he has done. In 2012, James developed a strategy for the United Nations, which was presented at Davos and became a central part of current UN mainstream humanitarian strategy. This strategy will influence the World 
Humanitarian Summit in Istanbul in July 2016. For James, participating in a project that began before 2012 and is continuing to have an impact four years later illustrates that the hard work a person places in their research now will have a lasting impact.

For students who have an interest in working in the realm of international development, James has a few pieces of advice. First, it is important to consider the career path. This line of work has been very rewarding and has provided James with numerous opportunities to see the world. However, a career such as this does come with the internationality aspect. Jobs in international development are found in either Washington, D.C. or abroad. Moreover, in order to embark on a career in international development, it is important to find a niche within the career that draws passion. Outside of school, do something of interest - start a club, study abroad, or participate in ASI. To all Cal Poly Students who are graduating and might be unsure of what direction to head in, take challenges as they come, learn how to speak publicly, seek out mentors, and push yourself to grow. 


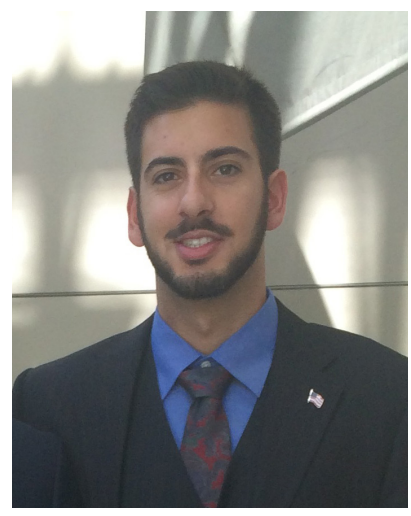

STEPHEN RICHARDSON is a third year Political Science student, concentrating in Pre-Law, and is a member of the Cal Poly Marksmanship club. Stephen is a Marine veteran who was stationed in Okinawa, Japan from 2009-2011 and plans on attending grad school after graduation. After studying in Rome in 2013, and traveling throughout Europe, he became increasingly familiar with the state of affairs in Europe. Stephen saw Putin dominating international affairs and his threat on the West, which sparked his interest in European Security, and Putin himself. Stephen hopes to put his degree into practice by eventually having a career in International Affairs or Diplomacy. 


\section{THE AGE OF PUTIN: GLOBAL IMPLICATIONS OF RUSSIA'S DOMESTIC POLICY}

Stephen Richardson

Vladimir Putin, a little known name when he was first appointed Prime Minister by his superior and later, predecessor, Boris Yeltsin in 1999 has embarked on an aggressive campaign to restore Russia to prominence. ${ }^{1}$ Many have noted that he seeks to rebuild Soviet Russia - a fair assessment given his youth the Soviet golden era, and with statements such as " $t]$ he collapse of the Soviet Union was a major geopolitical disaster of the century." Some of his recent actions, such as restoring Soviet symbols including the iconic Soviet five-pointed star and hammer $\&$ sickle, are further signs of his affections. ${ }^{3}$ President Putin has created a "strongman" image for himself that inspires the trust, respect and pride

\footnotetext{
1 "Vladimir Putin: The Rebuilding of 'Soviet' Russia." BBC News., March 27, 2014, http:// www.bbc.com/news/magazine-26769481.

2 Ibid.

${ }^{3}$ Ibid.
} 
Russians have in themselves and in their country. ${ }^{4}$ Confidence in leadership and pride in country at home is arguably what Putin is seeking 5 , but he certainly wishes to undermine the U.S.-led global order and reframe it so Russia is respected and treated as an equal to other great powers. ${ }^{6}$ Projecting power abroad solidifies President Putin's position at home, and creates a sense of patriotism and pride among the "remasculinized" Russian people. ${ }^{7}$ President Putin's assertive actions and rhetoric in Foreign Policy are certainly calculated for his domestic audience ${ }^{8}$ with the end-goal of Russian prominence. ${ }^{9}$ Thus it becomes apparent that Russia's Foreign Policy is an extension of her Domestic Policy. ${ }^{10}$

Many commentators - especially western, seem to see Putin as a mysterious figure who is somewhat unpredictable. ${ }^{11}$ This however is a foolish and lazy profiling, because Putin is very clear in what he wants, states it plainly and follows through with what he says. ${ }^{12}$ Much of the mystery around him will disappear if commentators pay notice to what he says and follow his actions. ${ }^{13}$ Putin reveals a lot of insight into his thinking in a speech he gave before the State Duma (Russia's Parliament) in August, 1999 while being appointed Prime Minister by Yeltsin. In that speech, he laid out the groundwork for his entire tenure in office by saying, "[w]e need to put an end to revolutions,

4 "Vladimir unbound: Russia's President is impervious to the woes that afflict normal leaders." The Economist, January 27, 2016, http://www.economist.com/news/europe/21689626-russias-president-impervious-woes-afflict-normal-leaders-vladimir-unbound.

5 Valerie Sperling, "A Case of Putin Envy: Behind the Obsession with Russia's Leader." Foreign Affairs, 5 Nov, 2015, https://www.foreignaffairs.com/articles/russian-federation/2015-11-05/case-putin-envy.

${ }^{6}$ Angela Stent, "Putin's Power Play in Syria: How to Respond to Russia’s Intervention." Foreign Affairs, January 1, 2016, 106-108.

7 Op. Cit., fn. 5

8 Ibid.

9 Op. Cit., fn. 1

${ }^{10}$ Markian Dobczansky, "Russia's Domestic and Foreign Policy Challenges." Wilson Center, July 7, 2011, https://www.wilsoncenter.org/publication/russias-domestic-and-foreign-policy-challenges.

${ }^{11}$ Op. Cit., fn. 1

${ }_{12}$ Op. Cit., fn. 6

13 Op. Cit., fn. 1 
these are staged so that nobody can be rich. But at the moment the country needs reforms so that nobody can be poor. Although this task, unfortunately, is becoming harder by the day. There is no such thing as a thriving state with an impoverished population... Russia's Territorial integrity is not subject to negotiation. Or, especially to horse trading or blackmail. We will take tough action against anyone who infringes upon our territorial integrity, using all the legal means available to us. Russia has been a great power for centuries, and remains so. It has always had and still has legitimate zones of interest abroad in both the former Soviet lands and elsewhere. We should not drop our guard in this respect, neither should we allow our opinion to be ignored." ${ }^{14}$

This makes it clear that he was aiming to launch a two-prong campaign to rebuild and reestablish Russia as a global power and one to be reckoned with. This campaign has had two clear fronts (prongs): the first of which, is a domestic policy to restore stability to the country to end "revolutions" that had previously diminished Russia's capabilities while the second, is his foreign policy where he seeks to regain Russia's place as a dominate world power that has a seat the highest levels in the international order and commands respect. ${ }^{15}$ On both of these fronts, Putin has proven to be rather successful, and in doing so has become immensely popular with his own people. ${ }^{16} \mathrm{He}$ has been so successful at this that he is even admired by some abroad - particularly among Americans who are critical of President Obama. ${ }^{17}$

For three years in a row - 2013-2015, Vladimir Putin was ranked by Forbes as the most powerful man in the world, a statement that is as understandable as it is controversial. ${ }^{18}$ This may come as a surprise given the dire economic situation Russia is in - largely at the hands of Putin, as well the widespread reporting of corruption and incompetence of the country's political system, shrinking and stagnating work force due to the falling oil prices, and

\footnotetext{
${ }^{14}$ Ibid.

15 Ibid.

${ }^{16}$ Op. Cit., fn. 5

17 Ibid.

${ }^{18}$ David M. Ewalt, “The World's Most Powerful People." Forbes, November 4, 2015, http://www.forbes.com/sites/davidewalt/2015/11/04/the-worlds-most-powerful-people2015/\#47dde7221868.
} 
crumbling infrastructure, namely in the periphery. ${ }^{19}$ On the flipside however, it may seem like common sense given his successful consolidation of power, impeccable military record, soaring popularity, and a foreign policy that has inspired admiration at home and awe abroad. ${ }^{20}$ Immediately upon taking power, Putin sought to reverse Yeltsin's policy of autonomy towards the regional governments in favor of a strong centralized state. ${ }^{21}$ Putin has relentlessly pursued these goals, effectively gaining this power consolidation that he has strived for. ${ }^{22}$ This accomplishment is impressive given the opposition he receives, much of which is predictably from the periphery (regional governments) whom feel they are either being neglected, having their toes stepped on, or both. ${ }^{23}$ Russia's corruption level is unusually high for a developed, wealthy country and ranks similarly to notoriously corrupt states such as Mali and Madagascar, coming in at $127^{\text {th }}$ in 2013 on the Corruption Perception Index. ${ }^{24}$ This and the economic difficulties faced by Russia due to economic sanctions that were brought on by Putin's aggressive foreign policy may make it seem odd to rank him the most powerful man in the world, when he is seemingly undoing his country that is already crumbling. ${ }^{25}$ Nevertheless, this may be masked by Putin's impressive popularity that has been consistently floating between $60-90 \%$ for his entire 15 -year career ${ }^{26}$ - considerably higher than that of many western leaders, especially American Presidents. ${ }^{27}$ Even

\footnotetext{
19 “Putin's War on the West." The Economist, February 14, 2015, http://www.economist. $\mathrm{com} /$ news/leaders/21643189-ukraine-suffers-it-time-recognise-gravity-russian-threatandcounter.

${ }^{20}$ Bingham G. Powell, Russell J. Dalton, and Kaaren Strom. Comparative Politics Today: A World View. Boston, MA: Longman, 2012, 348.

${ }^{21}$ Ibid.

22 Ibid.

${ }^{23}$ Ibid.

24 Op. Cit., fn. 1

${ }^{25}$ Evgenia Pismennaya and Anna Andrianova, "Russia's Economy Is Tanking, So Why Is Putin Smiling?” Bloomberg News, February 29, 2016, http://www.bloomberg.com/news/articles/2016-03-01/as-russia-s-economy-contracts-putin-s-preferred-indicator-is-up.

${ }^{26}$ Op. Cit., fn. 4

${ }^{27}$ George Gao and Samantha Smith, "Presidential job approval ratings from Ike to Obama." Pew Research Center. January 12, 2016, http://www.pewresearch.org/fact-tank/2016/01/12/ presidential-job-approval-ratings-from-ike-to-obama/.
} 
more important is how Putin has consolidated power in this dysfunctional system, and how much influence he exerts today, which as will be shown, knows few limits.

Immediately upon taking office, Putin sought to launch his assertive campaign to rebuild Russia to its former glory, seizing every opportunity afforded him and never backing down from a challenge that served his interests. If Sulla, Rome's first unlawful Dictator had the cunning of a fox and courage of a lion, then Putin has the cunning of a fox and formidability of a bear. $\mathrm{He}$ proved this immediately by launching the Second Chechen War in the same month he took office, in response to the separatist movement and humiliating defeat (stalemate) those ill-equip and poorly trained Chechen insurgents had inflicted on the once proud Russia, several years prior under the leadership of Yeltsin. ${ }^{28}$ In less than a year Chechnya was subjugated, restoring Russian pride, and Putin set a red line forever forbidding compromise over the small republics place in the Russian Federation. ${ }^{29}$ This made Putin a household name in Russia, whereas when he took office very few members of the State Duma had even heard of him, with some even pronouncing his name wrong. ${ }^{30}$

The next focus of his campaign, now that he attained gravitas, was crushing the Oligarchs, which he saw as parasitic towards Russia's economy and social vibrancy. A week before being elected President, Putin warned the Oligarchs that their reign was coming to an end - a threat he followed through with - and is one of his lasting legacies. ${ }^{31}$ Putin, in spirit of the gangsterism that had gripped Russia during the 1990's, gave the Oligarchs an offer they couldn't refuse - surrender power and a portion of your wealth in exchange for security and prosperity, or lose everything - most of whom refused. ${ }^{32}$ Thus the wrath of Putin was inspired, and the first targets he had in mind, were the media moguls, starting with Vladimir Gusinsky, owner of NTV the only independent national television station and the richest, most powerful man in

\footnotetext{
${ }^{28}$ Op. Cit., fn. 1

${ }^{29}$ Ibid.

${ }^{30}$ Ibid.

31 "Putin versus the Oligarchs?" The Economist, June 17, 2000, http://www.economist.com/ node/82208.

${ }^{32}$ Masha Gessen, "The Myth of the Russian Oligarchs." The New York Times, December 11, 2014, http://www.nytimes.com/2014/12/11/opinion/masha-gessen-the-myth-of-the-russian-oligarchs.html.
} 
Russian media. ${ }^{33} \mathrm{He}$ was forced into exile, and later arrested in Spain under charges of Fraud. ${ }^{34}$ Then Putin proceeded to eviscerate his media empire, or rather reorganized to fit the needs of the State. ${ }^{35}$ After this, non-state media at the federal level was effectively eradicated, and continuing to this day, all federal media outlets in Russia are either state owned or sponsored. ${ }^{36}$ The next major sacking, was that of Mikhail Khodorkovsky, the head of the oil group Yukos and one of the world's richest men. ${ }^{37}$ Thrown in jail under charges of tax evasion in 2004, his empire was seized by the state or more appropriately by Putin in a move that was seen by many as a war declared on the so called Oligarchs. ${ }^{38}$ This view was not unrealistic, as Putin would in fact seek to continue eradicating the Oligarchs, until they were essentially either of no concern to him, or firmly in his pocket. ${ }^{39}$

Putin's calculations have proven to be impeccable, he knew that in order to achieve his objectives he must first uproot corruption and consolidate sources of power. ${ }^{40}$ The sources of power he needed were in the grip of the Oligarchs, who would make his agenda difficult if it didn't suit their interests. ${ }^{41}$ Presumably then, this is the real reason that Putin declared "war" on them, a "war" which he has clearly won. ${ }^{42}$ This is significant, given that conventional wisdom in the West that Putin may be shooting himself in the foot by continuing aggressive foreign policies that get Russia slapped with more western-formed sanctions, because a slumping economy would surely provoke the Oligarchs. ${ }^{43}$ The problem with this analysis however, is that the "Oligarchs" being spoken of in popular consciousness have been

\footnotetext{
33 Ibid.

${ }^{34}$ Ibid.

35 Ibid.

${ }^{36}$ Ibid.

${ }^{37}$ Marshall Goldman, "Putin and the Oligarchs." Foreign Affairs, November 1, 2004, https:/www.foreignaffairs.com/articles/russia-fsu/2004-11-01/putin-and-oligarchs.

${ }^{38}$ Ibid.

39 Op. Cit., fn. 32

${ }^{40}$ Ibid.

${ }^{41}$ Ibid.

${ }^{42}$ Ibid.

${ }^{43}$ Ibid.
} 
all but snuffed out by Putin already. ${ }^{44}$ It's been years since Putin has ended the Oligarchy, and since 2004 he has consolidated power to a remarkable degree. ${ }^{45}$ Political Scientist Karen Dawisha calls the product of this consolidation "Kleptocratic Authoritarianism," an all-encompassing system of interlocking dependencies between various Russian elites and the Russian State. ${ }^{46}$ In this system there are three conditions for the new elite; first - they must pay to get into political office, second - they can use their office to accumulate greater wealth (as long as they stay in the good graces of Putin) and third - they may not use their offices to acquire greater political power. ${ }^{47}$ Thus the highest and most important positions in Russian society are little more than puppets to Putin, who essentially can exercise no independent political power outside the parameters he sets. In 2011, Mikhail Prokhorov, a billionaire tried to test the boundary of these new conditions by reshaping a pro-Kremlin political party and was immediately smacked down by Putin. When Prokhorov was threatened with having all his assets seized, he fell back in line and still remains loyal through this new economic hardship. ${ }^{48}$ In setting up this system, Putin has created a relationship where the new elite vies for power amongst each other, by kicking each other out or swallowing up smaller members, instead of pursing independent political agendas. ${ }^{49}$ This creates a safe guard for Putin himself, where he no longer has to worry about the elites trying to undo his power, as they don't have the means to challenge him without being eradicated and are too busy squabbling over each other. ${ }^{50}$ Thus Putin is the only one in this equation who is secure, and has created for himself a self-serving system that enables him to watch over his newly consolidated power, and keep his thumb on those who try to break out of it.

However, Putin's consolidation of power is not completely secure and is garnering resistance from different fronts- social and political resistance and an

\footnotetext{
44 Ibid.

45 Bingham G. Powell, Russell J. Dalton, and Kaaren Strom. Comparative Politics Today: A World View. Boston, MA: Longman, 2012, 348-349.

46 Op. Cit., fn. 32

47 Ibid.

48 Ibid.

49 Ibid.

50 Ibid.
} 
overall lack of social cohesion. ${ }^{51}$ The most famous examples of the resistance Putin faces are from the pro-LBGT community, spearheaded by the all-female punk band, "Pussy Riot." 52 These critics assert that Putin is setting up witch-hunts of gays to distract the population and turn them against themselves. ${ }^{53}$ This criticism is not unfounded - historically this type of scapegoating has been used in such a manner, as a mask to cover failing polices. ${ }^{54}$ Even more troubling to these proponents is the inhumane treatment jailed activists and innocent gays have been receiving. ${ }^{55}$ In response to this, Pussy Riot has set up a new organization to investigate and bring these troubles to light. ${ }^{56}$ Such investigations and corresponding activism have raised much awareness to the issue and has put immense pressure on Putin from outside sources, namely international humanitarian organizations. Before this, as late as 2013 most outsiders were more or less silent on the issue, or simply unaware. ${ }^{57}$ This has undoubtedly acted as a speed bump for Putin who wants a smooth sailing path to reform, and only further ads to the lack of trust in the government as a whole among the Russian population. ${ }^{58}$

Putin's arrangement with the new elites has sparked dismay from non-connected professionals and businessmen, as well as much of the domestic working class that is not in the immediate sphere of Moscow. ${ }^{59}$ Many have had enough of it, and are fleeing the country in great numbers. ${ }^{60}$ In some segments of the private sector, as much as $50 \%$ of professionals are either leaving or seeking to leave Russia in hopes of finding a better life, along with their fellow

${ }^{51}$ Kenneth Rapoza, "Russias three biggest Problems." Forbes, January 24, 2013, http://www. forbes.com/sites/kenrapoza/2013/01/24/russias-three-biggest-problems/\#3454e9ea6e55.

52 Nikita Sologub, “Under Suspicion: Death in a Siberian Cell.” The Guardian, March 9, 2015, http://www.theguardian.com/world/2015/mar/09/russia-siberian-cell-death-pussy-riot.

${ }^{53}$ Harvey Fierstein, "Russia's Anti-Gay Crackdown.” The New York Times, July 21, 2013, http:// www.nytimes.com/2013/07/22/opinion/russias-anti-gay-crackdown.html.

${ }^{54}$ Ibid.

55 Op. Cit., fn. 52

${ }^{56}$ Ibid.

57 Op. Cit., fn. 53

58 Op. Cit., fn. 51

59 Ibid.

${ }^{60}$ Ibid. 
disenfranchised homosexual citizens. ${ }^{61}$ This leads to a "brain drain" that not only drives away talent, but also inhibits the country's ability to attract foreign talent. ${ }^{62}$ Putin faces other problems with the workforce among those who choose to stay - he cannot afford to pay all his public employees and they are starting to protest his policies openly- placing direct blame on Moscow, if not Putin himself. ${ }^{63}$ These are problems that Putin is struggling with, and whether or not he has calculated for this particular development is unknown, but it certainly seems that he has no real plan to deal with it. ${ }^{64}$ Similar to these issues, Putin displays a lack of action in another weak area of Russian Society - corruption and incompetent political institutions on the periphery.

One of the most visible issues that is affecting the prosperity of Russia, is the rampant corruption that is extreme by the standards of developed countries, and a major hindrance towards stability and growth. ${ }^{65}$ Russia today is in a dire economic situation for the third time since the collapse of the Soviet Union - yet Putin is able to confidently address his people and say not to worry about the tough times ahead, out of a sense of patriotism - while scapegoating the West. ${ }^{66}$ Few leaders have the gal or ability to take this position or carry it out ${ }^{67}-$ but Putin remains steadfast, living up to his reputation of a "strongman President." ${ }^{68}$ Putin conveniently blames western sanctions placed on Russia, in retaliation to his forceful annexation of Crimea, but this is really a symptom of a larger problem; Russia's status as a "rentier state" who's economy is almost entirely dependent on its oil exports. ${ }^{69}$ Putin has understood this for a very long time and it is an issue he
${ }^{61}$ Ibid.
${ }^{62}$ Ibid.
63 Shellie Karabell, "Putin's Problem: Corruption, Not Just Sanctions." Forbes, December 22, 2014, http://www.forbes.com/sites/shelliekarabell/2014/12/22/putins-problems-corrup- tion-not-just-sanctions/\#1051e426f9cd.
${ }^{64}$ Ibid.
${ }^{65}$ Op. Cit., fn. 1
${ }^{66}$ Op. Cit., fn. 63
${ }^{67}$ Ibid.
${ }^{68}$ Op. Cit., fn. 5
${ }^{69}$ Op. Cit., fn. 63 
has attempted to address for many years, however this stifling corruption is an underlying hick-up and road block he continues to run into. ${ }^{70}$

The problem rests with an immensely large and complicated, if not contradictory set of business laws and regulations that enables courts, prosecutors and tax officials to pick and choose which regulations they uphold. ${ }^{71}$ This allows them great amounts of freedom in helping or hurting business - whichever is to their advantage. ${ }^{72}$ Natalya Volchkova of Moscow's New Economic School states that, "Regulation is about punishing business, not helping business to behave properly," and continues to insist that it is very easy for government officials to imprison business owners for the smallest infractions. ${ }^{73}$ She states that the tax inspector today is as feared as the KGB once was - they come regularly to inspect businesses and can easily spot "wrong doings" then slap the owner with a fine - which can be appealed in court, but in the meantime if that option is chosen, their accounts may be seized. ${ }^{74}$ This kind of regulatory practice is essentially a new kind of extortion reminiscent of the Russian Mafia's free reign in the 1990's. ${ }^{75}$ Putin has tried to address this issue (to what extent is unknown) but he faces resistance from tax officials across the board, and they promise to resist even more firmly if he persists, because they see reform as a threat to their livelihood. ${ }^{76}$ It would appear that this is one of the few areas where Putin's consolidated powers have been checked. Why exactly that is remains unclear, but one can deduce that Putin simply cannot afford to alienate these allies, as he already goes through great pains to ensure the loyalty of many other state officials that make such consolidations of power possible in the first place. ${ }^{77}$ The fact that Putin seemingly cannot address this issue is a challenge to his "strong man presidency" so he is therefore forced to cover it up. ${ }^{78}$ He does

\footnotetext{
${ }^{70}$ Ibid.

${ }^{71}$ Ibid.

72 Ibid.

${ }^{73}$ Ibid.

${ }^{74}$ Ibid.

75 Ibid.

${ }^{76}$ Ibid.

77 Ibid.

78 Op. Cit., fn. 78
} 
this by ensuring these issues are not brought to light in the media and by using the West as a scapegoat, in order to mask his own inability to address the issue. ${ }^{79}$ To this end, Putin's initiatives are a flying success, part of his genius, and partially why he has proven to be so successful in accomplishing his broader agendas.

To further add to the complication, Putin has sought to divert attention from domestic affairs altogether through his actions in Ukraine ${ }^{80}$, thus his foreign policy becomes an extension of his domestic policy. ${ }^{81} \mathrm{He}$ attempts to snuff out dissidence at home by stoking patriotism from actions abroad, and by successfully framing such actions as defensive against western inroads. ${ }^{82}$ With this understood, it's easier to understand his persistent actions in the Ukraine despite the hardships the entire country faces because of his seemingly selfish actions. The annexation of Crimea and barring Ukraine from entering the EU can partially be understood at the systemic level of analysis, as a matter of power given that Russia's "sphere of influence" has been gradually shrinking as the EU has been growing eastward since the end of the Cold War. ${ }^{83}$ This is problematic to Russian power because it limits the number of states who are in her sphere of influence. ${ }^{84}$ Further, it poses a challenge to Russia's preferred diplomatic and economic relations with Eastern European countries, especially Ukraine given its deep historic ties, strategic trade value and access to warm water in the Black Sea. ${ }^{85}$ At the State level, EU expansion can be seen as an encroachment on intangible power, as Ukraine is the homeland of the Russian people, giving it symbolic and

\footnotetext{
79 Ibid.

80 Op. Cit., fn. 19

${ }^{81}$ Op. Cit., fn. 10

82 Op. Cit., fn. 5.

${ }^{83}$ Roland Oliphant, "Vladimir Putin blames Nato expansion for rising tension with Europe." The Telegraph, January 11, 2016, http://www.telegraph.co.uk/news/worldnews/vladimir-putin/12093042/Vladimir-Putin-blames-Nato-expansion-for-rising-tension-with-Europe.html.

${ }^{84} \mathrm{Ibid}$.

85 "Putin the Uniter: The war has made most Ukrainians see Russians as enemies, not Friends." The Economist, June 20, 2015, http://www.economist.com/news/europe/21654663-war-has-made-most-ukrainians-see-russians-enemies-not-friends-putinuniter.
} 
social importance to Russians. ${ }^{86}$ This is significant given that the majority of those in eastern parts of Ukraine, who are ethnic Russians, support Putin and want closer ties with Russia, while the Russians themselves overwhelmingly support the actions of Putin and his image. ${ }^{87}$ Such actions, completely in defiance of the West, have increased Russian power in the eyes of Russians themselves, and created a sense of "Russian Machoism" that centers on Putin himself. ${ }^{88}$ The Russian Bear has convinced his countrymen at home that his actions abroad are for the preservation, power and security of the Russian Federation itself, quieting concerns over the troubled economy and stifling corruption. ${ }^{89}$ Putin has ingeniously gone about this campaign in a way that benefits both the state and himself, largely by stoking a stronger sense of patriotism - echoing the iconic phrase, "For the Motherland!"

In Syria we again see both systemic and individual level actions, where both the Russian Government and Putin himself benefits. Thanks to Putin, Russia benefits by embarrassing the United States, undermining her authority in the Middle East, and taking a larger seat at the negotiating table. ${ }^{90}$ Thus Russia now has a larger say in International Affairs, where it seems few issues concerning Europe and the Middle East can be addressed without her input. ${ }^{91}$ Putin benefits in that it is he himself who effectively wields this influence - where he continually stumps Washington, increases gravitas in the International Community, and improves his image at home. ${ }^{92}$ It is clear that the conduct of this crisis is dictated by, and done on behalf of Putin. ${ }^{93}$ It is his goals that are being sought, his power consolidation at home which makes it possible, and his diplomacy that routinely outfoxes the West.

In adopting this course of action, Putin has engineered a unique unitary autocracy that is centered on one person, rather than a series of institutions

\footnotetext{
86 Ibid.

${ }^{87}$ Op. Cit., fn. 1

${ }^{88}$ Op. Cit., fn. 5

89 Ibid.

${ }^{90}$ Op. Cit., fn. 6

${ }^{91}$ Ibid.

92 Ibid.

93 Op. Cit., fn. 19
} 
as in Iran, or a political party such as in China. ${ }^{94}$ His hybrid PresidentialParliamentary Government has become unrecognizable and incomparable to its model, the French Government. ${ }^{95}$ While he has enjoyed the power of vast consolidation, and a State Duma that essentially does as he orders, he faces an insurmountable problem of corruption and failing institutions that he cannot personally supervise on the periphery. ${ }^{96}$ The leaders of these institutions don't have the free range of movement in order to increase efficiency, and even if they did - corruption and bribery seems to hinder those efforts. ${ }^{97}$ His inability to diversify the economy is starting to sting badly, although his puppets and he seem to be detached from these economic hardships due to their plundering of the economy and amassing wealth for themselves, much of which is stored in foreign bank accounts. ${ }^{98}$

While the policies, actions and successes of the mighty Russian bear are impressive, they are not absolute and not without consequence. For all its promises, Putin's reforms have created some major kinks that need addressing. While his foreign policy has created an immensely popular image of himself domestically, globally his image is shaky at best. The same can be said of the Russian Federation which is indeed, respected, feared and powerful, but seemingly heading towards a weaker position. Despite his shaky image, Putin is arguably the most powerful man in the world - certainly the most dangerous, therefore he ought to be feared, not respected. His policies at home and actions abroad have far reaching consequences that affect the globe and the entire American-led international order. His interests dominate conversations on International Affairs, and have implications for us all, which is precisely what he wants and why we are living in the Age of Putin.

\footnotetext{
94 Bingham G. Powell, Russell J. Dalton, and Kaaren Strom. Comparative Politics Today: A World View. Boston, MA: Longman, 2012, 347-349.

95 Ibid.

96 Op. Cit., fn. 19

${ }^{7}$ Op. Cit., fn. 63

98 Op. Cit., fn. 78
} 


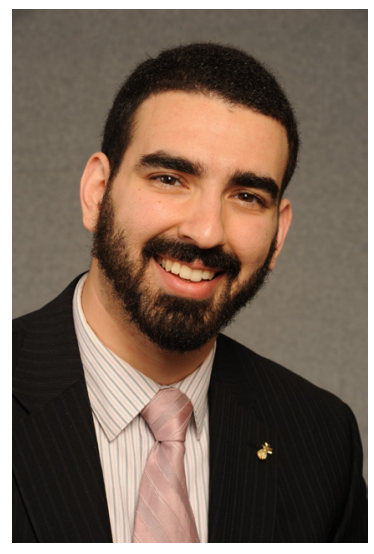

KAYVAN CHINICHIAN is the Associate Director of Individual Membership at the Atlantic Council in Washington, D.C. He graduated from Cal Poly in 2009 with a degree in Political Science. 


\section{ALUMNI SPOTLIGHT}

Kayvan Chinichian

From his first class at Cal Poly to graduation, Kayvan was always committed to the Political Science discipline. Though Kayvan did consider double majoring in either Economics or Business, ultimately the passion for politics and international relations (IR), coupled with a desire to put his coursework into action, outweighed the decision to have an additional major. Kayvan took up various opportunities offered by the College of Liberal Arts and the University to make the classroom come alive. He was involved in both Model United Nations (UN) and Mock Trial, and was an active member of the Persian Students of Cal Poly, where he and a small group of students raised the necessary funds to bring Nobel Peace Prize laureate and Iranian human rights advocate, Shirin Ebadi to speak at Cal Poly in 2007. In addition to that, Kayvan also was elected to the Board of Directors for ASI as a representative for the College of Liberal Arts.

After graduating from Cal Poly in 2009, Kayvan relocated to Washington, D.C. to pursue his passion for politics. Kayvan began his career, first as a translator, and then as a researcher for a variety of organizations including advocacy groups and think tanks in Washington, D.C. It was in the realm of think tanks that Kayvan felt his calling. Kayvan started with the 
Washington Institute for Near East Policy in 2009 and had a variety of positions that were both on the research side and on the non-profit management side. Before his time at that think tank ended, Kayvan was promoted to a Development Operations Officer. Kayvan spent five years at the Institute, and during that time, went to graduate school at the George Washington University Elliot School of International Affairs for a Master of Arts in Middle East Studies with a certificate in Political Management.

One of Kayvan's proudest accomplishments at the Washington Institute included organizing conferences to discuss various policy issues important to Middle East peace and security. The programs initially were expensive and aimless in terms of objectives, but over time and through dedicated management, these programs became lucrative for fundraising purposes and the conversations became more dynamic and fruitful for policy attendees.

Last year, Kayvan moved to another peer institution, the Atlantic Council, which was re-launching its membership program. Kayvan was enticed to take the opportunity because he wanted to take what he had learned from his previous positions and apply it to an entirely new program being built from the ground up. Working at the Atlantic Council provides Kayvan a significant amount of creative space to develop and grow his own program. Kayvan's current emphasis is to build a community of likeminded individuals who are committed to the work and mission of the Atlantic Council, while also raising critical financial resources to support the Council. The tagline for the Members Program that Kayvan manages is a "Global Network with a Global Purpose," and Kayvan continues to put a premium on making sure that this is truly a 'global' community he is helping to build. In addition to the Atlantic Council, Kayvan has also developed a passion for helping non-profits become successful in their efforts, and has been of assistance to organizations like the Nowruz Commission and the Turkish Policy Center.

For Political Science students who aspire to work in the non-profit space, Kayvan's most important recommendation is understanding the mission statement as well as the organization's objectives. Moreover, aspiring students interested in this space should understand that non-profits, like their peers in the for-profit space, provide opportunities for a whole host of skill sets. Understanding that aspect is important and should make 
the applicant be creative in how they present themselves to prospective employers. An additional recommendation by Kayvan is that students should not put too much of an emphasis on their research skills. Strong research skills are important, but ultimately employers are looking for other skills from job candidates. Finally, Kayvan stresses the importance of pursuing internships as they provide clarity and are an inexpensive tool to discovering a potential career path. Moreover, internships themselves become a vehicle for networking, which is crucial in today's job market and should not be taken for granted. 


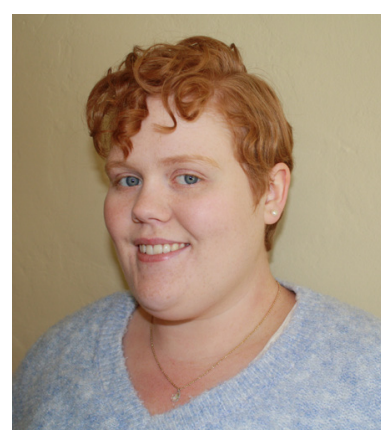

EMILY J. GAUNT is a graduating Political Science major in Spring 2016 with a concentration in Global Politics. After graduating, she plans to take a year off to travel to places such as Alaska with her family. When her year of exploration is up, she plans to buckle down to obtain her masters degree in International Relations. Emily's inspiration for this paper spurred from an eye-opening 60 Minutes story, "The Battle Above." She found the realities discussed in the 60 Minutes special as the perfect convergence of her fascinations with space and global politics. 


\title{
NEW AND CHANGING IMPLICATIONS OF EXPLORING THE FINAL FRONTIER: WHAT DOES U.S. DOMINANCE SIGNIFY FOR GLOBAL POLITICS?
}

Emily J. Gaunt

\begin{abstract}
The rapid boom in technological advances during the $20^{\text {th }}$ century transformed the dream of further space exploration from a dream to stark reality. The hostile relations of the Cold War that spurred the so-called "space race" gave way to international cooperation in space investigation. However, the cooperative tone experienced over the past few decades is not entirely indicative of the global political landscape. International space relations are still developing, as is the international space law. Without any formal authority over the regulation of space ventures, the possibility of dissension remains. This paper explores the potential for international conflict over the resources, control, and even military presence in outer space. The United States' dominance as the acting authority over outer space enterprises will result in a great impact global politics in both the near and distant future.
\end{abstract}




\section{Real World Observation}

On April 17, 2015, the $31^{\text {st }}$ annual Space Symposium was held in Colorado Springs, Colorado, at which, the secretary of the Air Force, Deborah Lee James, spoke about the importance of space utilization as well as maintaining U.S. dominance in the area of space technology. ${ }^{1}$ According to the Official Air Force Space Command website, the Secretary stated outright on the issue of competition in space that "the United States of America working shoulder to shoulder with our allies and partners, will not be bested." ${ }^{2}$ Secretary James discussed the top three issues that impact the future of the space domain. One of the Secretary's main priorities involves spreading awareness about the importance of space in everyday functioning, including satellite communications and international banking. The second point concerns the rapidly changing space environment. Outer space faces new threats such as excessive amounts of space debris, as well as the potential for hostile actions from competing nations through the use of anti-satellite technology, namely from China. Lastly, the secretary spoke about the importance of being prepared for the day that space is no longer a peaceful resource. ${ }^{3}$ The Secretary's message was clear, the United States will not relinquish any power from the domain of space. U.S. officials are adamant that military strategies must be adjusted to the demands of the political atmosphere of space.

Since the time of the initial Space Race during the Cold War, competing nations have had to interact in an under-regulated space, but U.S. dominance has always been present. Although there are several international treaties declaring the rights and responsibilities of countries, namely the requirement of the peaceful use of outer space, much activity is under the honor system of conduct. ${ }^{4}$ The lack of international regulation in outer space, combined with increased interest in space development, will likely have far-reaching implications here on earth. Many of the new areas of space remain unresolved areas of disagreement, including the advancement of profitable enterprises in outer space. Examples of the commercialization

\footnotetext{
${ }^{1}$ Tech. Sgt. Mike Slater, "Secretary of the Air Force James delivers message of confidence," Air Force Space Command Public Affairs (April 17, 2015).

${ }^{2}$ Ibid.

3 Ibid.

${ }^{4}$ Benjamin Soloway, "Lawyers In Space," Foreign Policy (April 15, 2015).
} 
of space involve tourism and asteroid mining. Soon, companies will offer commercial flights into space, provided that passengers are willing to pay a hefty fee. ${ }^{5}$ The possibility for conflict over space enterprises could become a reality faster that anyone can imagine. The United States is one step closer to preparing for a war in space, as illustrated by the insistence on defensive space technologies. The United States government simultaneously asserts dominance and claims space is a global utility. What many once thought was science fiction is now becoming a scientific reality.

Space has become the newest market of expansion and governments, as well as private companies, are changing the way the world looks at what was once declared a peaceful resource of shared human culture. ${ }^{6}$ Today, as countries continue to expand the knowledge of space and the benefits that earth can earn from expanding to the stars, nations are now required to interact in new ways that reflect modern interests. The scenarios that the U.S. presents are mostly hypothetical right now, aside from Chinese attempts at anti-satellite technology, but the possibility that conflict could occur over resources or access to satellites is a growing concern. The lack of international regulation in outer space could make this new era of space exploration a volatile one. This research argues that the U.S. will continue to maintain a unipolar space and seeks to explore the impact this dominance will have on global politics in the $21^{\text {st }}$ century.

\section{Conventional Wisdom}

It is the conventional wisdom that space is a peaceful resource for mankind to share as opposed to a potential conflict area. Generally, Americans are optimistic about the use and exploration of space. While the age of initial exploration into outer space was deemed a race during the Cold War, it was almost always considered to be a peaceful endeavor that could one-day benefit mankind. A Gallup poll from 2004 on the issue of public support for the space program reflects the conventional wisdom of space as a peaceful resource. In 2004, 67\% of Americans had at least some interest in the space

\footnotetext{
5 Alan Boyle, "After Accident, Virgin Galactic Takes a Cautious Path to Spaceflight," NBC

News (March 31, 2015).

6 Soloway, "Lawyers In Space."
} 
program and space exploration. ${ }^{7}$ The poll confirmed that most Americans believe that space should be a peaceful enterprise. When asked why they think governments explore space, most Americans believe it is for knowledge, global reputation as a leader in space, or that it benefits earth in some way. A mere $12 \%$ responded that the reason is "keeping the nation safe," by using space as some sort of defensive tactic. ${ }^{8}$ In a poll by the Pew Research Center in 2014, it was reported that the majority of Americans supported space travel and international cooperation of a space program. The support for technological advancement is overwhelming, with most Americans saying that these developments "will have a net positive impact on society" while $59 \%$ believe that innovations will improve the quality of life in the future. ${ }^{9}$ The conventional wisdom on the exploration of space and the advancement of technology is overwhelmingly positive and most of the public thinks of space as a beneficial resource for the world to share, not as a source of conflict in global politics.

The conventional wisdom concerning the advancement of space exploration and its implications on international relations is incomplete. Currently, the international community continues to cooperate in outer space. The expansion of space enterprises, however, presents opportunities for both growth and conflict. Ownership of mining resources, commercial space flight, and control over satellites are all areas of potential conflict. These new areas of conflict in outer space are missing from the conventional wisdom. It is the impact of these conflict areas, including satellites, resources, and the development of weapons, on global politics that this research explores.

\section{Theoretical Paradigm}

To investigate these conflict areas, this paper uses the theory of realism. Realism helps to explain and frame this research due to the theory's assumptions about the relative power of states being the primary cause of change in international politics. As realists assume that human nature is conflictual, the process by which space will become the new war zone can

\footnotetext{
7 Darren Carlson, "Space: To Infinity and Beyond on a Budget," Gallup (August 17, 2004).

8 Ibid.

9 Aaron Smith, "U.S. Views of Technology and the Future," Pew Research Center (April 17, 2014).
} 
be explained using principles of realism. As anarchy is the guiding force in global politics, international legal relations reflect the self-interest of states. These same principles can be applied to the utilization and expansion of space technologies. Though the United States is claiming that its system of satellites is a global utility, the government is ensuring that the control and benefits remain the right of the U.S.

The United States' insistence on remaining the only real power in outer space is reflective of the realist notions of state-centered interests. The U.S. is acting in such a way that reflects realist principles of international relations. By definition, realist countries cannot trust another nation. By stating that U.S. dominance will not be relinquished and demonstrating that the government has the ability to defend itself if need be, the United States is illustrating realism in action. The U.S. also understands that in asserting their dominance in space, a zero-sum game is being played, in which there will likely be multiple losers. Realist principles of self-interest set the stage for the U.S. to demand ownership of any resource found in space, which includes unique mining opportunities of rare materials from asteroids.

The conventional wisdom is better aligned with liberalism, and proponents would argue that the International Space Station (ISS) is evidence that the international community is capable of cooperation in space. However, most states have been shown to follow the realist pattern of behavior in international relations more so than expected liberal patterns. The driving force behind the initial exploration into space was conflict. Now that space technology has become essential to daily operations on earth, states will begin to wrestle with others over the possibility of gaining power at the level of outer space. Nations have already begun looking for chinks in the armor of the United States' technology in space. Recent testing of anti-satellite missiles indicates that the world may soon experience a higher form of warfare only seen before in fictional accounts of the future.

\section{U.S. Dominance Over Control of Satellites}

According to a 60 Minutes piece from April 26, 2015, the United States military is preparing for a potential all-out war in space. ${ }^{10}$ Much of the world relies on satellites for communication and Internet access, but the United

${ }^{10}$ David Martin, host, Andy Court, producer, "The Battle Above," 60 Minutes, CBS News (April 26, 2015). 
States in particular depends on satellites for national defense and military missions. The 60 Minutes script states that there is a new concern that vital "satellites are vulnerable to attack" from anti-satellite missiles, namely from China and Russia. ${ }^{11}$ The report from 60 Minutes claims that China has launched several anti-satellite missiles, creating U.S. concern. In 2007, a Chinese missile hit a Chinese satellite and created enormous amounts of space debris, which added about 3,000 pieces to the growing collection. ${ }^{12}$ According to NASA, there are over 500,000 pieces of space debris that are currently being tracked. ${ }^{13}$ Both man-made objects and naturally occurring objects, such as meteors, are considered debris. A single piece of rubble, traveling at over $17,000 \mathrm{mph}$, has the potential to do significant damage if it collides with satellites or spacecraft. ${ }^{14}$ In 2013, another Chinese anti-satellite missile reached an unprecedented height for such technology. Both China and Russia have been testing anti-satellite capabilities for decades. It is the occurrences of these tests that are motivating the U.S. military to reassert their dominance for the world to see in order to maintain a unipolar space. ${ }^{15}$ General Hyten, a military official interviewed by 60 Minutes, is clear that his mission allows for the use of force in the "defense" of space. The U.S. military can and will use military force to continue its reign in space.

The largely unknown branch of the U.S. Air Force known as Space Command is in charge of monitoring threats and preparing to respond to the potential for a war in space. According to General John Hyten of Space Command, the United States military relies heavily upon space technology, particularly satellites, to operate. The U.S. military has over 500 satellites and spends more than $\$ 25$ billion on space annually and will only continue to expand its capabilities. The actual costs of the program, however, continue to be difficult to pin down. ${ }^{16} \mathrm{~A}$ report from the Government Accountability Office on government funding found that between 2014 and 2018, the U.S. government will spend approximately $\$ 44$ billion on launch related

\footnotetext{
11 Ibid.

12 Ibid.

13 Mark Garcia, "Space Debris and Human Spacecraft," NASA. (September 26, 2013).

${ }^{14}$ Ibid.

15 David Martin, host, Andy Court, producer, "The Battle Above.”

16 Ibid.
} 
activities alone. ${ }^{17}$ While the U.S. frames its satellite system as a global utility, the message that the Air Force wishes to put forth is clear, the U.S. controls that utility as they see fit. The U.S. government has strategically designed its position of dominance in space technology. The existence of programs like space command implicates that governments are preparing for a new form of warfare. As General Hyten declared himself, Space Command is "not NASA" and the purpose of the military is to use force. Through the preparations to defend space, the U.S. may be creating its own self-fulfilling prophecy.

As early as 1997, the United States Air Force Space Command has seen the need for a long-range plan to ensure U.S. dominance. A report published by Space Command entitled "Vision for 2020" describes this plan. ${ }^{18}$ The report begins with an explanation of Space Command's mission to dominate military operations in outer space in order to preserve U.S. interests "by integrating space forces into war fighting capabilities across the full spectrum of conflict." ${ }^{19}$ The report illustrates the evolution of warfare and technology to explain how the military has risen to the occasion of land, sea and air threats and is now tasked with responding to the economic and military interests in space. The report refers to space as "the fourth medium of warfare," implicating the U.S. is preparing for combat in space. ${ }^{20}$ The report also details how the U.S. will attain what the report calls "Full Spectrum Dominance" in an effort to deny any adversaries' attempt to gather information, as the military depends on space technology for communications and remaining the eminent leader in gathering intel. ${ }^{21}$ Full spectrum dominance entails "concepts of dominant maneuver, precision engagement, full-dimensional protection, and focused logistics" in order to maintain space dominance and protect American interest in space. ${ }^{22}$

By 2010, Space Command expected to attain this dominance in order

17 Carl Levin, John McCain, Committee on Homeland Security and Governmental Affairs, "Space: Defense and Civilian Agencies Request Significant Funding for Launch-Related

Activities," United States Government Accountability Office, (September 9, 2013).

${ }_{18}$ Howell M. Estes, General USAF Commander In Chief, "United States Space Command

Vision For 2020," (February 1997).

19 Ibid.

${ }^{20}$ Ibid.

${ }^{21}$ Ibid.

22 Ibid. 
to gather information during peacetime, deter any sort of conflict, and ultimately be able to win any sort of conflict in space. The report accurately predicted that the future of technological developments would occur largely in the private sector, and anticipated that this shift would contribute to the widening wealth gap associated with globalization. The importance of space enterprises in the global economy is prioritized. This that concern over space technologies being attacked exists. To minimize the threat to space resources, military strategy has been adapted to the new trends in space development. ${ }^{23}$ The overall theme of the report is that space superiority is essential as the world becomes increasingly dependent upon satellites. The ability to maintain dominance as the global space power is the vision of Space Command and has been its mission since the 90 s.

The Department of Defense issued a press release on January 7, 2014 emphasizing the importance of space defense as an asset to the day-to-day functioning of military and civilian lives. ${ }^{24}$ General William Shelton of Space Command spoke of the concern over the threat to necessary satellites to students at George Washington University. General Shelton stated that although space technology provides the opportunity to prevent and aid in disasters around the world, societies' dependence on successful satellite operation presents new challenges for the military in the $21^{\text {st }}$ century. ${ }^{25}$ His main concern is that opponents are rapidly approaching the day when they can challenge U.S. dominance. General Shelton insists that military strategy must change to anticipate threats. Emphasizing that new crucial satellite construction must stay ahead of other nations. Additionally, the military should aim to complicate the targeting systems of competing forces. ${ }^{26}$

The evidence presented in this case study illustrates the United States' dominance over the control of space could create conflict on the world stage. The U.S. military has issued reports on their impression of the threats that space faces as well as the defense procedures necessary for protection. The insistence on U.S. dominance in space technology is reflective of realist

\footnotetext{
${ }^{23}$ Ibid.

${ }^{24}$ Jim Garamone, "Shelton Discusses Importance of Space Defense," Department of Defense American Forces Press Service, (January 7, 2014).

25 Ibid.

${ }^{26}$ Ibid.
} 
principles of state actions. ${ }^{27}$ Nations must now figure out what their reaction to this U.S. assertion in space dominance will be. The U.S. has been instituting its dominance for several decades, and now wants the world to comprehend that the U.S. military will defend its position as the world leader in space ventures. The sector of outer space is now at the forefront of global politics, and the U.S. is attempting to maintain the similar unipolar system that it currently has on earth. As nations develop new technologies, global politics will be impacted by the possibility of the fight over the control of valuable space enterprises.

\section{Conflict Over Resources}

The world constantly struggles to agree on the distribution of resources, such as food, water and precious products. With dwindling supplies of non-renewable resources, humanity is looking for new possibilities. The possibility that nations will begin to look at outer space for resources signifies another area for conflict in global politics as humankind moves into the twenty-first century. There are several different opportunities to seize as far as space resources go, including rare and valuable materials, expansion of agriculture and possibilities for new territories. For years, the human race has toyed with the idea of colonizing another planet and now science is starting to catch up with humanity's propensity for expansion. Private companies are now offering commercial flights into space, the price tag of which illustrates that space opportunities are not going to benefit all nations, but simply those with enough wealth. ${ }^{28}$

The ISS represents humanity's first steps toward colonizing space, in addition to earlier launches of manned rockets and the moon landings. Many believe that the ISS is just the beginning of the colonization of space. ${ }^{29}$ For more than twenty years, NASA has held the NASA Ames Space Settlement Contest for students under the age of eighteen to design a colony for humans to inhabit space. ${ }^{30}$ While this competition directly states that any design must

\footnotetext{
${ }^{27}$ Tech. Sgt. Mike Slater, "Secretary of the Air Force James delivers message of confidence."

${ }^{28}$ Boyle, "After Accident, Virgin Galactic Takes a Cautious Path to Spaceflight."

29 W. H. Siegfried, "Space Colonization-Benefits for the World," Space Technology and Applications International Forum, vol. 654, (February 2, 2003): 1270-1278.

${ }^{30}$ Al Globus, "NASA Ames Space Settlement Contest,” NASA.gov, (June 9, 2015).
} 
not be on any specific planet or space body, it involves a plan for humans to leave earth and live in a new space age with cutting-edge technology. According to the competition's web page, the result of mining one asteroid for materials "can build space colonies with living space equal to about 500 times the surface area of the Earth." ${ }^{11}$ This statement signifies that colonizing planets could be made possible with mining asteroids of valuable material. With further advancement of technology and motivation to leave what some fear is a dying earth, humans may be closer to colonizing space than solving the climate and population problems that earth faces.

While the potential for actually colonizing space may yet be several years off, the reality of space mining is not far off at all and is currently a major debate on the global stage. On May 22, 2015, the United States House of Representatives passed the SPACE Act a bill that gives businesses the right to any material that is mined out of asteroids. ${ }^{32}$ At this point, no company has actually announced realistic plans to mine asteroids, but the possibility has been floating around for years and the international community is faced with the issues of space commercialization. ${ }^{33}$ For a while now, the U.S. has been advocating for the ownership of mining resources in space to belong to the company that extracted them and the passage of the property rights bill signifies the transition from talking about the possibility of mining to a step forward in actual commercial space exploitation. ${ }^{34}$ Although the SPACE Act is concerning the privatization of asteroid mining resources, it still shows how the U.S. is grasping onto much of its power and even gaining more. The United States government has long endorsed the privatization of space as it frees up the federal budget for things like military space defense, which will ensure a stable market for American companies who work closely with government agencies..$^{35} 36$

\footnotetext{
31 Ibid.

32 Brian Fung, "The House just passed a bill about space mining. The future is here," Washington Post (May 22, 2015).

33 Soloway, "Lawyers In Space."

${ }^{34}$ Fung, "The House just passed a bill about space mining. The future is here."

35 Ibid.

${ }^{36}$ Estes, General USAF Commander In Chief, "United States Space Command Vision For 2020."
} 
Mining asteroids for valuable material is no new concept, but technology has now reached a point where mining is an actual possibility. Asteroid mining can be done in a variety of ways and could provide the earth with valuable materials that nations now desperately need. ${ }^{37}$ These materials include platinum, a precious metal used in electronics, palladium, which has a similar range of uses as platinum, and the highly useful resource of water. Asteroid mining could occur several different ways from onsite robotic extraction methods to towing and retrieval methods. ${ }^{38}$ Companies have long been working up ideas to mine near earth asteroids and now the technology to mine deep space asteroids is also becoming a reality. ${ }^{39}$ These companies include Deep Space Industries, Planetary Resources, and Bigelow Aerospace, all of which are eager to explore all that commercialized space has to offer, including space tourism and mining ventures. ${ }^{40}$

Passing the SPACE Act ensures that control over revenue from space mining practices remains partially in the hands of the United States. However, this bill is not mean that international organizations accept these property rights. International law on the ownership rights of mining resources does not yet exist and asteroid mining is still hypothetical. ${ }^{41}$ The passage of the SPACE Act signifies that the United States has both the intent and capacity to begin exploiting space resources for all that they are worth. A Department of Defense report from 2001 lays out the objectives for the future of the United States' involvement in space. The detailed report calls for an adequate understanding of the transforming way that space is used. ${ }^{42}$ One of the most important areas that the report stresses is the necessity to develop new technologies to maintain superiority and foresee threats and emerging industries. In order to accomplish this task, the U.S. would need "a healthy industrial base, improved science and technology resources, an attitude of risk-taking

\footnotetext{
${ }^{37}$ Kate Tate, "How Asteroid Mining Could Work," SPACE.com, (January 22, 2013).

${ }^{38}$ Ibid.

39 Ibid.

${ }^{40}$ Ibid.

${ }^{41}$ Soloway, "Lawyers In Space."

${ }^{42}$ Department of Defense Space Commission, "Report of the Commission to Assess United States National Security Space Management and Organization Pursuant to Public Law 10665," Department of Defense, (January 11, 2001).
} 
and innovation, and government policies that support international competitiveness." ${ }^{43}$ The SPACE Act is one of the ways these goals have come to fruition. The privatization of commercial space by the U.S. has furthered a unipolar control of space. Although the mining of asteroids has the potential to help all nations and peoples, the United States has come one step closer to assuring that it will control how these resources are dispersed, echoing the insistence that the satellite network is a global utility. While the U.S. claims that both satellites and resources are a global resource, there is a sector of space that is not remotely peaceful. In violation of international treaties, the U.S. has been quietly increasing weapons technology.

\section{Development of Space Weaponry}

In addition to conflict over U.S dominance over the fields of satellites and space resources, another potential area for global dissension involves the advancement of the weaponization of space. While science fiction writers have been using space warfare as a plot device for decades, space and weapons programs have had the intent and have been trying to attain the capacity to create the required technology to prepare for the day when space is no longer peaceful. In fact, there is significant evidence that the development of space weapons has now become a scientific reality. The field of weapons development is vast and varied, and the United States has shown that it is prepared to defend itself in space. ${ }^{44}$ The range of options for defense in outer space includes ground-to-space anti-satellite missiles, such as those that the Chinese have, ground-based lasers, airborne lasers, space-based conventional weapons, ballistic missiles with nuclear capabilities and much more. ${ }^{45}$

One leader in weapons development of the twenty-first century has been the United States' Defense Advanced Research Projects Agency (DARPA). The self-described mission of DARPA is to ensure that the U.S. remains the eminent producer of defense technology. ${ }^{46}$ According to a statement by the

\footnotetext{
43 Ibid.

${ }^{44}$ David Martin, host, Andy Court, producer, "The Battle Above."

45 SPACE.com Staff, “Top 10 Space Weapons," SPACE.com, (April 5, 2013).

${ }^{46}$ Tony Tether, Dr., "Statement By Dr. Tony Tether Director Defense Advanced Research Projects Agency Submitted to the Subcommittee on Emerging Threats and Capabilities Committee on Armed Services United States Senate," Defense Advanced Research Projects Agency, (April 10, 2002).
} 
director of DARPA in 2002, submitted to the United States Senate, DARPA is involved in the continuous transformation of military efforts in space. In addition to developing more affordable launch capabilities for satellite payloads, DARPA is involved in a space surveillance and advanced warning systems to threats posed to necessary satellites, called the Satellite Protection and Warning/Space Awareness (SPAWN). ${ }^{47}$ DARPA is also working on a space weapon that has the ability to utilize "electromagnets to shoot a stream of molten metal at incredible speeds toward enemy targets." ${ }^{48}$ This program, Magneto Hydrodynamic Explosive Munition (MAHEM) "offers the potential for higher efficiency, greater control, and the ability to generate and accurately time multiple jets and fragments from a single charge." 49

While the U.S. is denying the actual weaponization of space, officials are saying one thing and doing another. In 2001, Congress attempted to pass the Space Preservation Act of 2001 in order "[to] preserve the cooperative, peaceful uses of space for the benefit of all humankind by permanently prohibiting the basing of weapons in space by the United States, and to require the President to take action to adopt and implement a world treaty banning space-based weapons." 50 The bill sought a permanent ban on the development and use of weapons in space and to "remove from space any existing space-based weapons of the United States," indicating the possibility of the existence of space weapons designed by the United States. ${ }^{51}$ The bill defined weapons as any device capable of several things, including those that collide with and destroy an object in space. The bill cited the weaponization of space as:

The use of land-based, sea-based, or space-based systems using radiation, electromagnetic, psychotronic, sonic, laser, or other energies directed at individual persons or targeted populations for the purpose of information war, mood management, or mind control of such persons or populations;

\footnotetext{
47 Ibid.

48 SPACE.com staff, "Top 10 Space Weapons."

49 Dr. Kevin Massey, "MAgneto Hydrodynamic Explosive Munition (MAHEM)," DARPA. mil, (No date).

${ }^{50}$ Dennis Kunich, $107^{\text {th }}$ Congress, "Space Preservation Act of 2001," Federation of American Scientists, October 2, 2001.
}

${ }^{51}$ Ibid. 
or by expelling chemical or biological agents in the vicinity of a person. ${ }^{52}$

However, despite the intentions of this bill, it did not pass and according to the official website of the U.S. Congress, the bill received "Unfavorable Executive Comment" from the Department of Defense on April 19, 2002.53 As of 2008, the United States openly opposed a ban on weapons in space, according to the New York Times. ${ }^{54}$ The United Nations Conference on Disarmament, held in 2008, put forth a Russian-Chinese draft of an international treaty that sought to ban weapons in space in order to prevent another Cold War-style arms race. The United States rejected the ban, stating that the treaty would impede access to space and limit its use as well as the treaties lack of enforceability. ${ }^{55}$

The United States' refusal to pass the Space Preservation act of 2001, and the refusal to support any international treaty banning the use of weapons in space signifies that the U.S. does not want any inhibitors to the research and development of space weapons. Many weapons systems here on earth can be modified to be used as a weapon in space, including ballistic missiles and DARPA's MAHEM. In addition to MAHEM and other DARPA programs, there has been much speculation about space lasers. In the 1980s, the Strategic Defense Initiative, nicknamed Star Wars, introduced the world to a new form of defensive options. An article from the journal Nature discusses the reality and future of space weapons. The article reports on a Boeing designed prototype of a laser weapon, called the High Energy Laser Mobile Demonstrator (HEL MD), as being only one of several laser weapon options being developed for the United States government. ${ }^{56}$ While laser programs initially faced setbacks from feasibility restraints, laser weapons are now moving beyond obstacles and optical fiber laser technology is rapidly becoming the go-to choice. ${ }^{57}$ Some expect that laser weapons could be put into fully operational use

\footnotetext{
52 Ibid.

${ }^{53}$ Dennis Kunich, “H.R.2977 - Space Preservation Act of 2001,” Congress.gov, (2001-2002).

${ }^{44}$ Nick Cumming-Bruce, "U.N. Weighs a Ban on Weapons in Space, but U.S. Still Objects," New York Times, February 13, 2008.

55 Ibid.

${ }^{56}$ Andy Extance, "Military technology: Laser weapons get real," Nature, May 27, 2015.

57 Ibid.
} 
for military defense in five to ten years. ${ }^{58}$ For space, this advancement means that the United States military is that much closer to establishing full dominance in all fields of space development. The U.S. continues to deny any official weaponization of space, but actions indicate a contradiction on the matter. The weaponization of space without transparency in international relations represents the final stage in achieving dominance in space technology and development.

\section{Ramifications of Findings}

The research findings implicate that the world is headed toward a new era in international interaction in space. The dominance of the United States in the areas of space technology and defense has been very publicly asserted. Competing nations, namely China, have been shown to be exploring at least the option of challenging that dominance. Technology programs all over the world have the potential to catch up and adapt to this new space age if the concerns of Space Command leaders are valid. At the very least, these concerns illustrate the changing dynamics of space as well as the potential for space to see combat. International regulation of space has proven incompetent to adequately resolve the possibility of conflict over access to space ventures and resources. Thus far, the national response from the U.S. has been to simply confirm dominance through legal action and public displays. In each area that the U.S. has asserted dominance, the potential for international conflict over the next several decades exists.

Government contracts for the development of weapons that can one day be utilized in space, combined with U.S. dominance in control over satellites operated by military forces and closely working with the privatization of space, will have significant impacts on global politics. The United States is implementing all its power to maintain full spectrum dominance and control over space technology and has shown that it has both the intent and the capacity to accomplish a unipolar space. However, this attempt at asserting dominance does not entirely deter competition. Competing nations around the world will soon possess the ability to go up against American technology, or at least begin developing programs with the intent to challenge U.S. dominance. With the competition over access to space resources, satellites, and the development of weapons in space, global leaders must acknowledge the potential for conflict in outer space.

\footnotetext{
58 Ibid.
} 


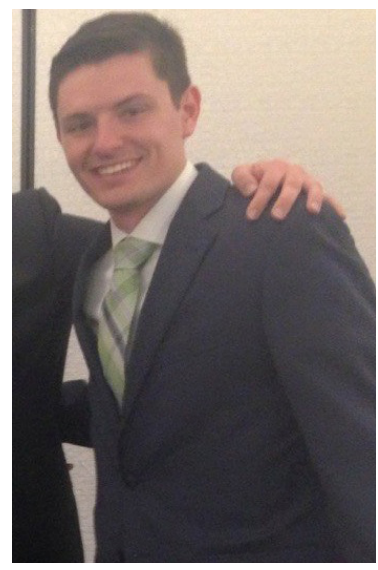

TROY GABRIEL is a fourth year Political Science major, concentrating in Global Politics. He has participated in Cal Poly's Model United Nations club, attending conferences in New York City and San Francisco. Troy wrote this paper for a Contemporary U.S. Foreign Policy class and chose this topic because of the frequency with which public opinion polls on current events are cited in the news. Finding himself curious about the effectiveness of these polls on decision-making, Troy decided to examine case studies to understand the relationship between public opinion and foreign policy decisions in America. After Troy graduates, he plans on joining the Peace Corps, teaching English, before attending graduate school. 


\title{
WILL OF THE PEOPLE: PUBLIC OPINION AND U.S. FOREIGN POLICY \\ Troy Gabriel
}

\begin{abstract}
This research paper examines how effective public opinion is at influencing U.S. foreign policy and makes predictions on what this relationship will look like in the future. The research was qualitative in nature, examining information found in speeches and remarks made by government actors as well as the general public. The research focused on two case studies; the Vietnam War and the Iraq War, and found that the top decision maker in government at the time of each conflict, namely the President, carried out policies that often disregarded public opinion entirely. The implications of this research indicate that as the U.S. attempts to retain its hegemonic status, future foreign policy decision will become less representative of the masses and will more closely resemble an oligarchy rather than a democracy.
\end{abstract}

\section{Real World Observation}

On September 10, 2014, The New York Times reported that President Barack Obama had authorized a military campaign against the Sunni militant group 
known as ISIS, or the Islamic State of Iraq and Syria. ${ }^{1}$ The authorized campaign calls for American airstrikes in Syria as well as the deployment of 475 military advisors to Iraq. ${ }^{2}$ These military advisors are being sent in order to assist the Kurdish and Iraqi forces with more training, intelligence, and equipment against these fighters. ${ }^{3}$ President Obama made it clear that these forces will not be used in any combat capacity, but will strictly be there to support U.S. allies in the region. ${ }^{4}$ This new authorization will bring the total number of American troops in Iraq to 1,600. ${ }^{5}$ The President also called on Congress to authorize the allocation of resources in order to "train and equip" the opposition forces fighting the Assad regime in Syria. ${ }^{6}$ This new authorization comes just two weeks after the President was criticized for not having a strategy to deal with the rising threat, paralleling the change in public opinion, ${ }^{7}$ with $53 \%$ of adults approving of the plan. ${ }^{8}$

This rapid change in the administration's position towards ISIS is not an outlier in the history of executive action, and it is important to put this most recent announcement into the context of recent history. A year to the day before the speech President Barack Obama gave regarding ISIS, he gave a speech discussing America's involvement Syria. ${ }^{9}$ In it, Obama argued the benefits of limited airstrikes in Syria, ${ }^{10}$ counter to the prevailing opinion of the public of noninvolvement. ${ }^{11}$ Just a few weeks earlier, Obama stated that

${ }^{1}$ Mark Landler, "Obama, in Speech on ISIS, Promises Sustained Effort to Rout Militants," The New York Times, September 10, 2014.

2 Ibid.

${ }^{3}$ Statement by the President on ISIL. The White House, September 10, 2014.

${ }^{4}$ Ibid.

5 Lander, "Obama, in Speech on ISIS."

6 "Statement by the President on ISIL." The White House

7 Lander, "Obama, in Speech on ISIS."

8 "Bipartisan Support for Obama's Military Campaign Against ISIS," Pew Research Center for People and the Press, September 15, 2014.

9 Katie Zezima, "How Obama's second Sept. 10 Syria speech in a row was different this year - and how it wasn't," The Washington Post, September 10, 2014.

${ }^{10}$ Remarks by the President in Address to the Nation on Syria. The White House, September 10, 2013.

11 "American Views on Intervention in Syria," The New York Times/CBS News Poll, September 10, 2013. 
he "will seek authorization for the use of force from the American people's representatives in Congress" and not use his executive authority. ${ }^{12}$ The choice by the president to defer the decision to Congress, and not use executive action, shows that this is not the first time Obama has entertained the public's interest in foreign policy matters. An earlier example occurred near the end of the Bush administration. In 2007, 63\% of the public was in favor of their congressional representatives voting for a bill to withdraw troops from Iraq in the next year. ${ }^{13}$ The following year, Bush announced that there would be a withdrawal of 8,000 troops by February of 2009, appearing to give in to the public's will. While Bush wielded his authority in order to appease the public, Obama left the decision up to Congress, or the people directly. ${ }^{14}$ These instances show that the quick policy decisions and changes made by executives occur regardless of the administration, and give context when looking at other historical examples.

The influence that public opinion has on the executives who make contemporary U.S. foreign policy is a very important relationship study, and has profound implications for how we understand the formulation of American foreign policy. If U.S foreign policy is always guided by the prevailing public opinion, polices can be shortsighted and overlook key issues. The tendency for policies to not be as informed if guided by public opinion can be seen in a study done by Rogers, Stuhler, and Koeing in which they find that there is a "large gap" between the opinions of knowledgeable experts and that of the general public. ${ }^{15}$ The researchers go on to make the assertion that the foreign policy opinions of experts were "specific, many-sided, analytical, and flexible," while the general public's opinions "tended to be vague and sporadic." ${ }^{16}$ On the other hand, if public opinion is not a part of the equation in U.S. foreign policy formulation, then is it still accurate to label the U.S. as a

\footnotetext{
12 Statement by the President on Syria. The White House, August 31, 2013.

13 "A Summer of Discontent with Washington," Pew Research Center for the People and the Press, August 2, 2007.

${ }^{14}$ Ewen MacAskill, "Bush limits Iraq troop withdrawal to 8,000 and orders 'quiet surge' in Afghanistan,” The Guardian September 9, 2008.

${ }^{15}$ William C. Rogers, Barbara Stuhler, and Donald Koeing, "A Comparison of Informed and General Public Opinion on U.S. Foreign Policy," The Public Opinion Quarterly, Vol. 31, No. 2 (Summer, 1967): 242-252.
}

${ }^{16}$ Ibid. 
representative democracy? It seems as if public opinion has an effect on the formulation and path of U.S. foreign policy, but it is unclear by how much of a role it plays. This uncertainty leads me to ask the following question: How effective is public opinion at influencing U.S. foreign policy?

\section{Conventional Wisdom}

The democratic ideal of a responsive, representative government illustrates the prevailing belief that public opinion matters in both domestic and foreign issues. This ideal is an essential part of American political culture, one that the public whole-heartedly believes in. For instance, in a poll conducted by World Public Opinion, $81 \%$ of respondents said that when governmental leaders are making an important decision, they "should pay attention to public opinion polls because this will help them get a sense of the public's views." ${ }^{17}$ This finding is further backed up by the principle expressed in the Universal Declaration of Human Rights, that "the will of the people should be the basis of the authority of government," with $87 \%$ of Americans agreeing. ${ }^{18}$ In a study done by the Pew Research Center for People and the Press, polling data shows that the long-range policy priorities of the general public and the Council on Foreign Relations (CFR) are similar in several key areas. ${ }^{19}$ Both believe that protecting the U.S. from terrorism is a top priority, with $83 \%$ of the public and $76 \%$ of the CFR. There is also large overlap in regard to preventing the spread of Weapons of Mass Destruction, with $73 \%$ of the public and $81 \%$ of the CFR making it a priority. ${ }^{20}$ When there is large overlap between the opinions of the public and those of policy elites, it seems clear that public opinion is effective at influencing foreign policy. However, the idealism of democracy is not always the reality of democracy, and it would be a mistake to draw such a conclusion.

This conventional wisdom is misleading because it suggests that the general public has a direct role in which policies are top priorities, when evidence

17 "American Public Says Government Leaders Should Pay Attention to Polls," World Public Opinion.org, March 21, 2008.

${ }^{18}$ Ibid.

19 "Public Sees U.S. Power Declining as Support for Global Engagement Slips: America's Place in the World 2013," Pew Research Center for the People and the Press, December 3, 2013.

${ }^{20}$ Ibid. 
suggests otherwise. Such evidence can be seen when looking at the public's opinion on the war in Iraq. At the start of the war in 2003, public support was at a high of $74 \% .{ }^{21}$ Yet just a few years later in 2007 public support for the war had dropped to $40 \%$, with a majority of $53 \%$ of the public favoring withdrawal. ${ }^{22}$ Even though the majority opinion favored a change in policy, the change did not happen for another 4 years, when the war officially ended. ${ }^{23}$ If the conventional wisdom were entirely true, the timeline of the war would have paralleled the changes in the public opinion. The fact that it didn't show that foreign policy is not always influenced by public opinion, illustrates a flaw in the conventional wisdom.

\section{Theoretical Paradigm}

To best understand the research question and the case studies presented, the research is framed using the theoretical paradigm of U.S. foreign policy known as group dynamics. This theory was defined by Dorwin Cartwright and Alvin Zander as a "field of inquiry dedicated to advancing knowledge about the nature of groups, the laws of their development, and their interrelations with individuals, other groups, and larger institutions." ${ }^{24}$ In regard to U.S. foreign policy and international relations, the theory of group dynamics is predicated on the belief that special interests or elites, not the state, influence political outcomes. ${ }^{25}$ This general beliefs leads to the other core assumptions of the group dynamics theory. The first of these core assumptions is that decision-making actors are susceptible to the influence of groupthink. ${ }^{26}$ The people in a decision-making position are constantly interacting with others in their respective groups. These interactions in the group might "exert pressures for conformity to group norms," ${ }^{27}$ an inherently bad thing, as it

\footnotetext{
${ }^{21}$ Scott Keeter, "Trends in Public Opinion about the War in Iraq, 2003-2007," Pew Research Center, March 15, 2007.

22 Ibid.

23 “Barack Obama: All US Troops to Leave Iraq in 2011,” BBC News, October 21, 2014.

${ }^{24}$ Dorwin Cartwright and Alvin Zander, "Origins of Group Dynamics," Group Dynamics, $3^{\text {rd }}$ Edition, (1968): 3-21.

25 C. Wright Mills, The Power Elite (Oxford University Press, 1956).

${ }^{26}$ Ole R. Holsti. "Models of International Relations and Foreign Policy." Diplomatic History 13 , no 1 . (1989).

27 Ibid.
} 
can "inhibit the search for information and policy options . . suppressing some forms of intragroup conflict that might serve to clarify goals, values, and opinions." ${ }^{28}$ A second core assumption of group dynamics theory is that when it comes to the group of decision-makers, "the power elite," 29 its members are from small group of "political, economic, and military men." ${ }^{30}$ According to this assumption, this group comes from "the upper third of the income and occupational pyramids," which makes this group relatively unrepresentative of the majority. It is this assumption that is most pertinent to the research presented in this paper. $^{31}$

Group dynamics, and the assumptions stated above, is the most appropriate and fitting theory to frame and explain the influence of public opinion on U.S. foreign policy. First, group dynamics' assumption that individuals or groups, not the state, influence political outcomes helps frame the case studies presented in this paper regarding decisions of Presidents during wartime. This is due to the concept of groupthink, since the policy decision makers are not interacting with the public on a daily basis, and do not view the public as their peers. The people they do interact with daily, their peers, will inherently place pressures on the decision makers to appease or conform to the group thinking, potentially having "a significant impact on the substance and quality of decisions." ${ }^{32}$ This theory has a negative viewpoint concerning the research question. The fact that the decision maker group is separate from the public opinion suggests that they therefore do not have an influence on policy formulation. The second assumption made by this theory regarding the make-up of the "power elite" further highlights its usefulness when framing the answer to the research question. By assuming that the power elite are comprised of an unrepresentative minority of industry leaders, the ineffectiveness of the public opinion's influence becomes clear. How can public opinion compete with the influence that this small group of people have, a group who are interacting with each other every day and developing personal relationships? It is because of these assumptions that

\footnotetext{
28 Ibid.

${ }^{29}$ Mills, The Power Elite

${ }^{30}$ Ibid.

31 Ibid.

${ }^{32}$ Holsti, "Models of International Relations and Foreign Policy."
} 
the theory of group dynamics best frames the answer to the research question presented in this paper.

\section{The Vietnam War}

The military operation in Vietnam that lasted from November 1955 until April 1975 is one of notoriety in United States history. It was a timed filled with protests and civil disobedience, as well as a period in which the leaders of the U.S. faced the challenge of balancing policy they deemed appropriate and the policy the public demanded. In retrospect, most people, public and policy elite, consider the Vietnam engagement as a mistake, one some deem an "important history lesson." 33 Yet when this was a contemporary issue, that sentiment was not as wide spread, with many of the policy elites deeming the war effort a righteous one based on democratic principles. ${ }^{34}$ Due to the contradictory relationship between the public and the policy elites during the Vietnam War, this period is important to consider when attempting to answer the research question.

In order to study this relationship properly, it will be important to approach this case study in a chronological fashion. By observing how the war developed over time, and the policy decisions that affected it, the cause and effect relationship between the public opinion and the policy decisions should become apparent. U.S. involvement in Vietnam began during the Eisenhower administration in November of $1955 .{ }^{35}$ Initially, U.S. involvement played a strictly supportive role, not a military one. In Eisenhower's Annual Budget Message to the Congress for the Fiscal Year of 1956, he proposed to "furnish defense support to several countries" in Southeast Asia, Vietnam included. ${ }^{36}$ This was in response to the general fear of Communist subversion at the

\footnotetext{
33 "Anti-War Sentiment Dominates Talk Airwaves," Pew Research Journalism Project, August 30, 2007.

${ }^{34}$ Lyndon B. Johnson: "Annual Message to the Congress on the State of the Union," January 12, 1966. Online by Gerhard Peters and John T. Woolley, The American Presidency Project.

${ }^{35}$ U.S. Department of Defense. Press Operations. "Name of Technical Sergeant Richard B. Fitzgibbon to be Added to the Vietnam Veterans Memorial." (November 6, 1998).

${ }^{36}$ Dwight D. Eisenhower: "Annual Budget Message to the Congress: Fiscal Year 1956," January 17, 1955. Online by Gerhard Peters and John T. Woolley, The American Presidency Project.
} 
time. ${ }^{37}$ The prevailing belief of foreign policy elites was the Domino Theory, which theorizes that in order to prevent fighting at home the U.S. must engage the Communist ideal in foreign countries, lest the weaker states fall and Communism comes knocking on the U.S.'s doorstep. ${ }^{38}$ Due to this fear of Communism, those who were informed generally accepted the assistance to a number of Southeast Asian countries that Eisenhower had proposed, but the majority of U.S. citizens were unaware of the involvement at all. ${ }^{39}$ Due to this lack of an informed public, the public opinion of such a policy was irrelevant to the policy elites at the time, since there simply was not one. The lack of an obvious public opinion lead most policy leaders to believe that a policy of assistance to these countries was one that was supported by most. This was seen in the next administration, when President John F. Kennedy informed the President of the Republic of Vietnam that the U.S. would promptly increase the assistance to the Vietnamese defense effort in $1961 .^{40}$ Yet this ambiguity of the public towards Vietnam policy would soon change.

The development of a public opinion towards U.S. involvement in Vietnam took off during the Johnson administration. At the onset of his administration, President Lyndon B. Johnson followed his predecessors' example, only gradually increasing the support sent to Vietnam. ${ }^{41}$ By 1965 the President was "convinced that the country, for the most part, [was] with him; that there [was] only a small minority dissent from his Vietnam policies." ${ }^{42}$ This belief led the President to continue with the Vietnam policy that he deemed appropriate, increasing the extent of U.S. involvement in the war by authorizing air strikes on military targets

\footnotetext{
37 Ibid.

${ }^{38}$ Jean Collins, "The Domino Theory," The North American Review, Vol. 252, No. 3 (May, 1967): 19-20.

39 William L. Lunch and Peter W. Sperlich, "American Public Opinion and the War in Vietnam," The Western Political Quarterly, Vol. 32, No. 1 (March, 1979): 21-44.

${ }^{40}$ John F. Kennedy: "Exchange of Messages With the President of the Republic of Viet-Nam.," December 15, 1961. Online by Gerhard Peters and John T. Woolley, The American Presidency Project.

${ }^{41}$ Lyndon B. Johnson, "Annual Budget Message to the Congress, Fiscal Year 1965," January 21, 1964. Online by Gerhard Peters and John T. Woolley, The American Presidency Project.

${ }^{42}$ Lester Markel, "Public Opinion and the War in Vietnam," The New York Times, August 8, 1965 .
} 
and increasing the U.S. fighting force to 190,000 men. ${ }^{43}$ In the same speech, Johnson addressed the American people with a forceful statement; "The days may become months, and the months may become years, but we will stay as long as aggression commands us to battle," a statement that was a prelude to the arduous future of the war. ${ }^{44}$ It seems that this was an example in which policy elites were influenced by the public opinion, yet this is not the case, as the belief in the support of the majority that Johnson held was an inaccurate one. An article published in The New York Times on March 27, 1966 reported, "many thousands took part in demonstrations during the day" in a number of large cities throughout the U.S. ${ }^{45}$ In New York City, there were between 20,000 and 25,000 marchers on Fifth Avenue alone. ${ }^{46}$ Protests were taking place in other cities around the country on that same day, likely with similar numbers. It would be a mistake to consider an active vocal group numbering in the tens of thousands as a "small minority of dissent." ${ }^{47}$ A study done by the Gallup organization the following year found that a majority of respondents to a survey disapproved of the way that President Johnson was handling the situation in Vietnam, ${ }^{48}$ further showing the inaccuracy in the amount of support for President Johnson. Even as evidence was presented that suggested the policy choices that the President made were not following the policy decisions the public wanted, Johnson remained steadfast on his policy choices. In his State of the Union Address in 1968, Johnson outlined how increased support for the war was needed and authorized the deployment of additional 13,500 men, only weeks after he had sent about 11,000 additional Marine and airborne troops. ${ }^{49}$ This decision made by the President shows just how ineffective public opinion was at influencing U.S. foreign policy during this administration.

\footnotetext{
43 Johnson, "State of the Union." (1966).

${ }^{44}$ Ibid.

${ }^{45}$ Douglas Robinson, “Thousands on Fifth Ave. March in Vietnam Protest," The New York Times, March 27, 1966.

46 Ibid.

47 Markel, "Public Opinion and the War in Vietnam."

48 Gallup Organization, “Gallup Poll \# 1967-0742: Vietnam War/1968 Presidential Election," March 9-14, 1967.

${ }^{49}$ Lyndon B. Johnson, "The President's Address to the Nation Announcing Steps To Limit the War in Vietnam and Reporting His Decision Not To Seek Reelection," March 31, 1968. Online by Gerhard Peters and John T. Woolley, The American Presidency Project.
} 
As the Nixon administration took over, many members of the public hoped that Nixon would simply end the war immediately by ordering the U.S. forces home. ${ }^{50}$ Yet Nixon did not do this, stating, "I would have betrayed my solemn responsibility as President of the United States if I had done so." ${ }^{11}$ This is an extremely telling quote, as it gives insight into the mindset of foreign policy elites. According to Nixon, adhering to the whims of the public opinion, concerning foreign policy, is a terrible thing for the country as a whole. This is counter to the prevailing popular belief in Democratic Theory, in which the public should be an important actor in governmental decision-making. ${ }^{52}$ If policy elites share this belief, it might explain why public opinion is ineffective in influence U.S. foreign policy.

By 1971, it was common knowledge among the public and policy elites that polling data showed an overwhelming majority of Americans wanted the troops out of Vietnam by the end of the year, with a staggering $75 \%$ of people reputing the President's policy. ${ }^{53}$ Even with such a large majority of the American public calling for an end to the war in Vietnam, it persisted through the rest of the Nixon administration and into the Ford administration. U.S. involvement in Vietnam did not end until President Gerald Ford announced on April 29, 1975 that "the military situation in the area [Saigon] deteriorated rapidly... I therefore ordered the evacuation of all American personnel remaining in South Vietnam." 54 The public had finally achieved what they wanted, after voicing their opinion for over a decade. It is clear that during the Vietnam War public opinion was at best commentary about the war, with little influence over foreign policy formulation. Instead, the policies made by policy elites during the war were the policies they deemed most appropriate, regardless of the public opinion. President Nixon stated this in a response to a letter he received from a university student, "the policies we are now following reflect our own best judgment,

\footnotetext{
${ }^{50}$ Richard Nixon, "Address to the Nation on Vietnam," May 14, 1969. Online by Gerhard Peters and John T. Woolley, The American Presidency Project.

51 Ibid.

52 "American Public Says Government Leaders Should Pay Attention to Polls," World Public Opinion.org.

53 Reo M. Christenson, "Vietnam and Public Opinion," The New York Times July 3, 1971.

${ }^{54}$ Gerald R. Ford, "Statement Following Evacuation of United States Personnel From the Republic of Vietnam," April 29, 1975. Online by Gerhard Peters and John T. Woolley, The American Presidency Project.
} 
based on exhaustive study of all the available evidence, of how to achieve that goal. To abandon that policy merely because of a public demonstration would therefore be an act of gross irresponsibility on my part." ${ }^{25}$ This sentiment would persist through many administrations, guiding executives like George W. Bush to continually disregard the majority public opinion in favor of the policy elite throughout his involvement in the Iraq War.

\section{The Iraq War}

The Iraq War is another important case study to examine as it shares many similarities with the Vietnam War, such as a supportive public in the beginning with a quick shift to public dissatisfaction as the war wore on. Meanwhile, policy elites and administration officials remained steadfast in their commitment to see the war through, claiming the fighting was for democratic principles just as their predecessors did forty years before. ${ }^{56} \mathrm{~A}$ key difference, however, between the two conflicts is the fact the onset of the Iraq War was brought on by the terrorist attacks carried out on September 11, 2001 against the United States, while there was no attack on U.S. soil before the Vietnam War. ${ }^{57}$ Another key difference is that the Vietnam War spanned across four different administrations, while the Iraq War only spanned two. It is important to shed light on these differences as they have implications on the mood of the public opinion, and therefore are an important aspect of this research. In order to understand the relationship shared between U.S. foreign policy and the public opinion it will again be important to continue through this case study chronologically. Again, this will help to illustrate the cause and effect relationship between public opinion and foreign policy decisions.

As stated before, the catalyst of the Iraq War was the 9/11 terrorist attacks in New York City. It was originally believed that Iraq and the Hussein regime

\footnotetext{
${ }^{55}$ Richard Nixon, "Letter to University Student Randy J. Dicks on the "Vietnam Moratorium," October 13, 1969. Online by Gerhard Peters and John T. Woolley, The American Presidency Project.

${ }^{56}$ George W. Bush, "Remarks on Signing the Emergency Supplemental Appropriations Act for Defense and for the Reconstruction of Iraq and Afghanistan, 2004," November 6, 2003. Online by Gerhard Peters and John T. Woolley, The American Presidency Project.

${ }^{57}$ George W. Bush, "Address to the Nation on Iraq," March 17, 2003. Online by Gerhard Peters and John T. Woolley, The American Presidency Project.
} 
had supported al-Qaeda to some capacity in carrying out the attack, ${ }^{58}$ and that it was working to acquire weapons of mass destruction (WMDs). ${ }^{59}$ Due to the passage of the "Joint Resolution to Authorize the use of United States Armed Forces against Those Responsible for the Recent Attacks Launched against the United States," the president had the authority to "take military action against any nation, organization, or persons that had been involved in the 9/11 attacks." ${ }^{60}$ The Bush administration was determined to include Iraq in this group, and in his 2002 State of the Union Address, Bush began his campaign to do this. In his speech he labeled Iraq as a member of a new "axis of evil" consisting of states aimed at threatening the peace of the world. ${ }^{61}$ He would continue to define how big of a threat Hussein was to the United States throughout the year, until, on October $10^{\text {th }}$ and $11^{\text {th }}$, Congress passed the "Authorization for Use of Military Force Against Iraq Resolution of 2002." ${ }^{2}$ By March of the following year, the United States had begun military operations in Iraq, ${ }^{63}$ and by May of that same year, President Bush announced that, "major combat operations in Iraq have ended" from the deck of the U.S.S. Abraham Lincoln. ${ }^{64}$

So what was going through the minds of the American public throughout this period of quick, policy decisions? Well, in general, most of the public

${ }^{58}$ George W. Bush, "Letter to the Speaker of the House of Representatives Transmitting a Supplemental Appropriations Request for Ongoing Military and Intelligence Operations in Iraq, Afghanistan, and Elsewhere," September 17, 2003. Online by Gerhard Peters and John T. Woolley, The American Presidency Project.

${ }^{59}$ George W. Bush, "Address Before a Joint Session of the Congress on the State of the Union,” January 29, 2002. Online by Gerhard Peters and John T. Woolley, The American Presidency Project.

${ }^{60}$ Ole R. Holsti, American Public Opinion on the Iraq War (University of Michigan Press, November 2011).

${ }^{61}$ Bush, "Address before a Joint Session of Congress on the State of the Union," 2002.

${ }^{62}$ U.S. Congress. House of Representatives. International Relations Committee. 2002. $A u$ thorization for Use of Military Force Against Iraq Resolution of 2002. $107^{\text {th }}$ Congress, Second Session, October $10-11$ and October 16.

63 George W. Bush, "Address to the Nation on Iraq," March 19, 2003. Online by Gerhard Peters and John T. Woolley, The American Presidency Project.

${ }^{64}$ George W. Bush, "Address to the Nation on Iraq From the U.S.S. Abraham Lincoln," May 1, 2003. Online by Gerhard Peters and John T. Woolley, The American Presidency Project. 
was supportive of the policy, with Bush's approval rating reaching a peak of $76 \%$ after the fall of Baghdad. ${ }^{65}$ It was easy for the public to support such a foreign policy since the war effort was to prevent Iraq from acquiring WMDs, further the growing "global war on terrorism," ${ }^{66}$ and promote democracy. ${ }^{67}$ This might suggest a causal relationship between the public opinion and the policy decisions made, however causality is not present. The policies made by the Bush administration at the onset of the Iraq War were not in response to public polling data, but rather policies the administration wanted to pursue. ${ }^{68}$ Paul Wolfowitz, the United States Deputy Secretary during the first term of the Bush administration, stated, "We settled on [WMDs as the core reason to go to war because] everyone could agree." ${ }^{69}$ It was not as though the public believed Iraq had WMDs and then pressured their elected officials to pursue a more aggressive policy, but rather the elected officials framing their policy so "everyone could agree." ${ }^{70}$ However, this massive support would not last, and as of 2004, Bush's approval rating began a slow, consistent, decline. ${ }^{71}$

At the beginning of 2004, public opinion for the Iraq War was positive, with between $54 \%$ and $58 \%$ saying that the war was not a mistake. ${ }^{72}$ Five months later, after the announcement that the U.S. would transfer sovereignty back to Iraq, polling data found that the percent of Americans in support of the war had fallen to $46 \%{ }^{73}$ A large majority of the public believed that the transfer of power was a sign that U.S. policy was failing because the transfer occurred before the U.S. could bring about stability in the country. ${ }^{74}$ When asked how long they thought the U.S. should have a significant number of troops in Iraq,

\footnotetext{
${ }^{65}$ Joseph Carroll, “The Iraq-Vietnam Comparison,” Gallup Organization, June 15, 2004.

${ }^{66}$ Holsti, American Public Opinion on the Iraq War

${ }^{67}$ Bush, "Remarks on Singing the Emergency..." 2003.

${ }^{68}$ Holsti, American Public Opinion on the Iraq War

69 Ibid.

${ }^{70}$ Ibid.

${ }^{71}$ Carroll, "The Iraq-Vietnam comparison"

${ }^{72}$ Ibid.

${ }^{73}$ Lydia Saad, "Americans Applaud Transfer of Sovereignty to Iraq: Have mixed expectations for future of Iraq," Gallup Organization, June 29, 2004.

${ }^{74}$ Ibid.
} 
the study found that a majority said less than a year. ${ }^{75}$ By the end of the year, a majority of people disapproved of the United States' decision to go to war with Iraq. ${ }^{76}$ The quick decline in public approval for the Iraq war is likely due to the lack of any evidence suggesting Iraq had WMDs and revelations made by the 9/11 Commission. In October of 2003, David Kay, the head of the group responsible for locating WMDs in Iraq, gave a preliminary report to Congress in which he stated that his inspection team had failed to find any WMDs in the country. ${ }^{77}$ The summer of the next year, the 9/11 Commission found that there was "no credible evidence that Iraq and al Qaeda had cooperated on attacks against the U.S." ${ }^{78}$ These findings showed that the Bush administration was incorrect when they began to formulate the Iraq policy that would define the decade. These blunders of the administration are likely what led to the quick change in public opinion.

By 2005, the growing public opinion was that the war in Iraq was going badly for the United States. ${ }^{79}$ Regardless, the Bush administration pushed on with their Iraq policy. In an interview on CNN, then Vice President Dick Cheney stated, "we'll leave as soon as the task is over with." ${ }^{80}$ President Bush continued in this rhetoric when he said, "we're not leaving, so long as I'm the President." ${ }^{11}$ The true effect or lack thereof, that public opinion had on foreign policy during the Iraq War is evident when listening to Bush's own words regarding the matter, "I don't think you've ever heard me say, 'Gosh, I'd better change position because the polls say this or that'... I'm going to do what I think is right, and if people don't like me for it, that's just the way it is." ${ }^{82}$ This idea became practice when Bush committed an additional 20,000 American

\footnotetext{
75 Ibid.

${ }^{76}$ Jeffrey M. Jones, "Public's Evaluation of Iraq War Grows More Negative: Americans still divided over decision to go to war," The Gallup Organization, December 22, 2004.

77 Holsti, American Public Opinion on the Iraq War

${ }^{78}$ Ibid.

79 Joseph Carroll, "Americans' Views of the Iraq War Sour: President Bush's approval ratings on Iraq hold Steady at 42\%," The Gallup Organization, May 5, 2005.

${ }^{80}$ Dick Cheney, interview by Larry King, CNN Larry King Live, May 30, 2005.

${ }^{81}$ George W. Bush, “The President's News Conference,” August 21, 2006. Online by Gerhard Peters and John T. Woolley, The American Presidency Project.

82 Ibid.
} 
troops and an additional carrier strike group to Iraq, ${ }^{83}$ even as polling data showed that $60 \%$ of Americans believed that originally sending troops to Iraq was a mistake, ${ }^{84}$ and a majority believed that U.S. troops should be withdrawn from Iraq within a year. ${ }^{85}$ It was not until the end of 2008 that Bush finally announced a decrease in the U.S. military presence, when he stated, "Iraqi forces will now take the lead in security operations in Anbar, with American troops moving into an over-watch role." ${ }^{\text {86 }}$

De-escalation of U.S. military involvement in Iraq began when President Barack Obama took office in 2009. In a speech given at Camp Lejeune, North Carolina, the President announced that the U.S. combat mission would end by August 31, 2010, leaving only transitional forces to be removed by the end of $2011 .^{87}$ The war was finally over on December 15, 2011 when the President announced that the troops were preparing to make their final march out of the country. ${ }^{88}$ The Iraq War is evidence of the ineffectiveness that public opinion truly has on U.S. foreign policy. For half of Bush's Presidency, the policy decisions he was making were the policy choices that the majority public opinion didn't want. Perhaps because of this, "nearly two-thirds say his administration will be remembered more for its failures than its accomplishments." ${ }^{99}$

\section{Implications}

The ineffectiveness that public opinion has on U.S. foreign policy is telling of the future of how the U.S. public, and the world, views U.S. foreign policy. As other states make gains in catching up to the United States in terms of

\footnotetext{
${ }^{83}$ George W. Bush, "Address to the Nation on Military Operations in Iraq," January 10, 2007. Online by Gerhard Peters and John T. Woolley, The American Presidency Project.

${ }^{84}$ Jeffrey M. Jones, "Opposition to Iraq War Reaches New High: Sixty-three percent say U.S. made mistake in sending troops," The Gallup Organization, April 24, 2008.

${ }^{85}$ David W. Moore, "Three Years of war Have Eroded Public Support: majority of Americans want U.S. troops home within a year," The Gallup Organization, March 17, 2006.

${ }^{86}$ George W. Bush, "Statement on the War on Terror in Iraq," September 1, 2008. Online by Gerhard Peters and John T. Woolley, The American Presidency Project.

${ }^{87}$ Barack Obama, "Remarks on Military Operations in Iraq at Camp Lejeune, North Carolina," February 27, 2009. Online by Gerhard Peters and John T. Woolley, The American Presidency.

${ }^{88}$ Barack Obama, "The President's Weekly Address," December 17, 2011. Online by Gerhard Peters and John T. Woolley, The American Presidency Project.

89 Keeter, "Trends in Public Opinion about the War in Iraq, 2003-2007."
} 
hegemonic power, the U.S. attempts to retain their unipolar status, most notably with the "pivot to Asia," which is "aimed at increasing America's influence in Asia" to counter a growing China. ${ }^{90}$ At the same time, the United States has the ongoing mission of spreading democracy and the ideals that are a part of it. ${ }^{91}$ This is clear when looking at the case studies presented in this paper, for administrations in both the Vietnam ${ }^{92}$ and $\operatorname{Iraq}^{93}$ war claimed a large part of the war effort was to spread democracy. Due to the fact that these are important policy issues for the United States, the foreign policy decisions made in the future will become ever important.

The future importance of foreign policy decisions reveal the inaccuracy of the conventional wisdom that public opinion should and does have a large amount of influence over U.S. foreign policy decisions. . It is clear from the research findings that policy elites do not adhere to the will of the people when it comes to foreign policy decisions, but rather, "must necessarily engage in the process of 'manufacturing consent' from the public." 94 This "manufactured consent" is highlighted by Ole R. Holsti, who wrote, "policies are chosen beforehand, polls used to spin them." ${ }^{95}$ The idea presented here shows just how policy is formed without thinking of the public opinion. In fact, according to Holsti, the only important thing that the public opinion is good for is learning how to sell policy decisions to the public. This "manufactured consent" is evidence that decision-making is becoming more concentrated in the power elite. The power elite is extremely under representative of the public, as it is comprised of industry leaders from political, economic, and military sectors. ${ }^{96}$ These members consider each other as "among those who count," ${ }^{97}$ effectively stating that the public does not count, and therefore the

\footnotetext{
${ }^{90}$ David Nakamura, "On Asia trip, Obama makes the case for U.S. relevance - and his own," The Washington Post, November 15, 2014.

${ }^{91}$ Ibid.

92 Johnson, "Annual Message to the Congress on the State of the Union."

93 Bush, "Remarks on Signing the Emergency Supplemental Appropriations Act for Defense and for the Reconstruction of Iraq and Afghanistan, 2004"

94 Walter Lippmann, Public Opinion (New York: Macmillan, 1992).

${ }_{95}$ Holsti, American Public Opinion on the Iraq War.

96 Wright, The Power Elite

97 Ibid.
} 
public opinion does not count or matter. As the decision makers of foreign policy become more concentrated in the "power elite," the foreign policy decisions will become less representative of the public. This will cause the future of U.S. foreign policy to resemble an oligarchy rather than a democracy, potentially a hindrance to the United States' ability to spread democratic ideals overseas. It is clear from the research presented that public opinion is not at all effective at influencing U.S. foreign policy. 


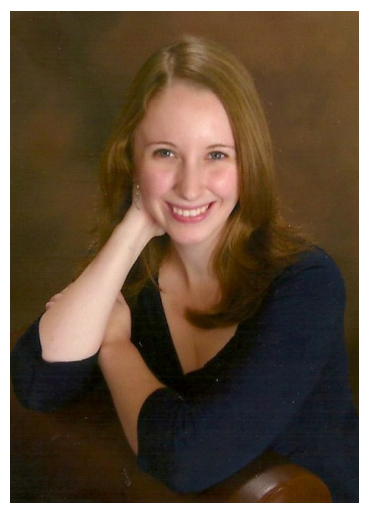

LAUREN LINDSAY is an Associate at Quinn Emanuel Urquhart \& Sullivan, LLP. She graduated in 2008 with a Political Science degree. 


\section{ALUMNI SPOTLIGHT}

\section{Lauren Lindsay}

Lauren's interest in law began with a childhood argument between herself and a friend, who told Lauren that she should be a lawyer. "She may not have meant that in a good way, but it got me thinking," said Lauren. This spark of interest followed her into high school, where she joined her school's mock trial team. At that point she knew exactly what she would study in college. Lauren came to Cal Poly as a Political Science major and went on to obtain a minor in Psychology, as well as a concentration in Pre-Law, and by graduation she would leave a lasting legacy on campus.

Disheartened by the fact that Cal Poly had no mock trial club at the time, Lauren worked with Dr. Moore in her junior year to create the first team on campus. They went to a handful of competitions, and the experience of that first team led to the club being added as the class that students enjoy today. Lauren also contributed to campus by becoming a LINKS mentor in her sophomore year, helping at-risk freshmen with their work and guiding them through the challenges of their first year at college. She further helped students by working for Student Support Services as a writing advisor in the last half of her college career. 
Cal Poly assisted Lauren by supporting her development through opportunities for internships, which contributed to her present successes. In the summer between her junior and senior years Lauren got a job at the Monterey County District Attorney's Office in the Domestic Violence Unit, where she worked one-on-one with an attorney to prepare for a murder trial. This internship was a great learn-by-doing moment for her and she cites this experience as one of the reasons she got into law school. Lauren's favorite class at Cal Poly was Civil Liberties, taught by Dr. Den Otter, because it exposed her to the type of class she would be taking in law school and because of Dr. Den Otter's lively and engaging presentation of the material.

Lauren graduated in 2008 and went directly to the UCLA School of Law. In between each year in law school, she acquired real-world legal experience from multiple jobs. Even before going to college, Lauren had worked for a federal district court judge as an extern (short-term intern), which gave her a "behind-the-scenes look" at the judiciary. While at UCLA, she worked as a Summer Associate at Quinn Emanuel Urquhart \& Sullivan, LLP, where Lauren currently works today. Then, about a year after graduating from law school and starting as an Associate at Quinn Emanuel, she took the opportunity to spend a year clerking for a federal judge in the United States District Court for the Central District of California. This was a great learning experience for Lauren, who says, "It really helped me to understand the life-cycle of a case because you get to see cases at all different stages." The clerkship helped her hone her skills and gave her a high degree of access to the decision-making process of the court, teaching her valuable lessons about the most effective way to present an argument.

Once her clerkship was over, Lauren rejoined Quinn Emanuel as an Associate, where she specializes in business litigation. Her responsibilities cover a wide range of skills, from legal research and writing briefs to preparing for settlement conferences and trials. Lauren has been back with Quinn Emanuel for almost two years now, and although her focus is in business law, she also has an interest in pro bono work.

Lauren says the most important thing for students to know before studying law is to be sure that a career as a lawyer is what they truly want. Student debt is her main worry for students today. Lauren explained that students should not "just go to grad school because you're not really sure what else to do." Lauren's experiences at Cal Poly contributed to where she is today, 
and she hopes that others seize the opportunities they have in college to get practical experiences in courts and law offices prior to embarking on a legal career to get firsthand exposure to what the day-to-day operations are like. 


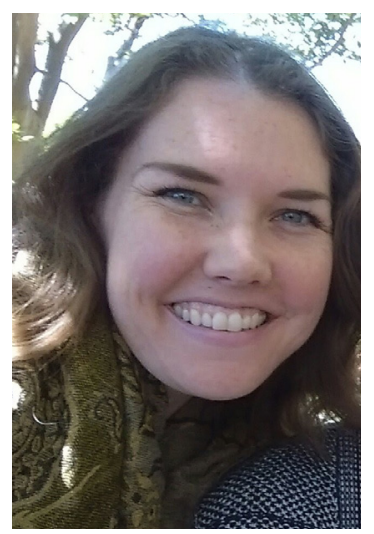

DANIELLE VEATCH is a first year graduate student in the Master of Public Policy program. Her inspiration for this paper comes from her experience in working with individuals who have experienced trafficking first hand. She began working against human trafficking five years ago, and currently assists a local non-profit agency with developing a safe house for survivors. Danielle's ambition after graduating is to develop an international organization that provides safe homes for survivors in the most marginalized countries in the world. 
BRIEFING MEMO: SEX TRAFFICKING

Danielle Veatch

\section{Executive Summary}

Sex trafficking affects an estimated 1.4 million people worldwide, and is prevalent in almost every country. ${ }^{1}$ It is a gross violation of human dignity and directly violates an individual's right to personal autonomy. ${ }^{2}$ This international crime preys upon vulnerable populations, abusing weaknesses and exploiting individuals for economic profit. Sex trafficking is the second largest and the fastest growing transnational crime, with industry profits of $\$ 31.6$ billion a year. ${ }^{3}$ This issue also greatly impacts the safety of the public and especially youth, as the average age of entry into sexual exploitation,

\footnotetext{
${ }^{1}$ Besler, Patrick. "Forced labor and human trafficking: estimating the profits." International Labor Organization. 2005. http://www.ilo.org/wcmsp5/groups/public/@ed_norm/@declaration/documents/publication/wcms_081971.pdf.

2 United Nations. "United Nations Convention against Transnational Organized Crime." United Nations Office on Drugs and Crime. 2000.

${ }^{3}$ Global Financial Integrity. "Transnational crime in the developing world.” 2011. http:// www.gfintegrity.org/storage/gfip/documents/reports/transcrime/gfi_transnational_crime_ web.pdf.
} 
or child sex trafficking, is 12 to 14 years of age. ${ }^{4}$ Within the United States, stakeholders at all levels must continue to collaborate and work diligently together to further develop effective solutions, including holistic prevention, intervention, and restoration measures. In comparison to other nations, the Nordic Model has and continues to show promising results for Sweden as well as many other countries. Within the U.S., implementation of the Nordic Model would decriminalize sex trafficking victims, prosecute clients and traffickers strictly, and reduce the entry and re-entry into sex trafficking.

\section{Common Interest}

Sex trafficking is a heinous crime, as victims endure "severe physical injuries, including stabbings, beatings, broken bones, spinal injuries, concussions, and fractured skulls, and psychological impacts include clinical depression, self-cutting, suicide, and post-traumatic stress disorder." 5 Sex trafficking poses a severe threat to the public and especially children. Using mentally and physically coercive techniques, traffickers, also known as pimps, manipulate and control victims. Within the general public anyone is a target, however, youth are easy to mold and influence, especially abused, neglected, and or poor youth. Interest, gifts, and or adoration from a trafficker posing as a boyfriend, savior, or helper lures such individuals away from safety and initiates the process of sex trafficking. ${ }^{6}$ Additionally, women and girls, unlike drugs or weapons that only have one to two buyers, are frequent subjects in multiple transactions throughout the day and throughout their time in trafficking. Consequently, they are reusable assets and fetch larger profits for traffickers. ${ }^{7}$ Thus, increased safety of the public, and specifically children, must be at the forefront of the U.S.'s agenda in combatting sex trafficking, both nationally and internationally.

\footnotetext{
${ }^{4}$ Polaris Project. Child trafficking and the child welfare system. 2014. www.polarisproject. org/storage/child-trafficking-child-welfare.pdf.

5 Mishra, V. "Combating human trafficking: gaps in policy and law." Sage Publications, 2015.

${ }^{6}$ U.S. Department of Education. "Human trafficking of children in the United States."

U.S. Department of Education. 2013. http://www2.ed.gov/about/offices/list/oese/oshs/ factsheet.html.

${ }^{7}$ Claude, K. "Targeting the Sex Buyer: the Swedish example, stopping prostitution and trafficking where it all begins." Swedish Institute. 2010. http://exoduscry.com/wp-content/ uploads/2010/07/swedish_model.pdf.
} 
Sex trafficking impacts almost every nation in the world. Countries serve as a source and destination location for trafficking women, children, and occasionally men, from one country to another. Sex trafficking is the second fastest growing transnational crime and third most profitable. ${ }^{8}$ Victims are displaced, and many times unable to return home due to immigration issues, as documents are taken away and used to control victims. ${ }^{9}$ Transnational Organized Crime (TOC), in relation to sex trafficking, often "penetrates governments...exacerbating corruption and undermining rule of law, judicial systems, free press, democratic institution-building, and transparency. TOC networks insinuate themselves into the political process in a variety of ways: through direct bribery, setting up shadow economies, infiltrating financial and security sectors through coercion or corruption, and positioning themselves as alternate providers of governance, security, services, and livelihoods." 10 Thus, the decrease of TOC is crucial in the U.S.'s objective to fight sex trafficking.

\section{Trends}

The International Labor Organization estimates that between cross-border trafficking and trafficking within countries, 1.4 million people are victims of sex trafficking. ${ }^{11}$ Major source countries, or origin of trafficked persons, include: Brazil, Colombia, Mexico, Nigeria, Morocco, Myanmar, and Vietnam. ${ }^{12}$ Major destination countries, where victims are brought to perform sexual services, include: United States, Canada, the European Union, Japan, Australia, Turkey, and Saudi Arabia. ${ }^{13}$ Sex trafficking is a transnational crime, having both source and destination countries. ${ }^{14}$ As

\footnotetext{
8 United Nations. "Trafficking in Persons: global patterns." United Nation Office on Drugs and Crime. 2006. http://www.unodc.org/pdf/traffickinginpersons_report_2006ver2.pdf.

${ }^{9}$ Polaris Project. The victims and traffickers. 2011. https://polarisproject.org/victims-traffickers.

${ }_{10}$ National Security Council. "Transnational organized crime: a growing threat to national and international security." The White House. 2015. https://www.whitehouse.gov/administration/eop/nsc/transnational-crime/threat.

${ }^{11}$ Op. Cit., fn. 1

${ }^{12}$ Op. Cit., fn. 8

${ }^{13}$ Op. Cit., fn. 8

${ }^{14}$ United Nations. "Trafficking in Persons: global patterns." United Nation Office on Drugs and Crime. 2006. http://www.unodc.org/pdf/traffickinginpersons_report_2006ver2.pdf.
} 
illustrated in Figure 1, a large percentage of victims of source countries come from impoverished nations. ${ }^{15}$ Poverty significantly contributes to the vulnerability of individuals and increases the likelihood of being trafficked. ${ }^{16}$ Destination countries are primarily first-world nations, where hypersexuality is more prevalent. ${ }^{17}$ Thus showing a demand and supply effect. The sex trafficking industry profits $\$ 31.6$ billion a year and is the second most prolific organized crime industry worldwide. ${ }^{18}$
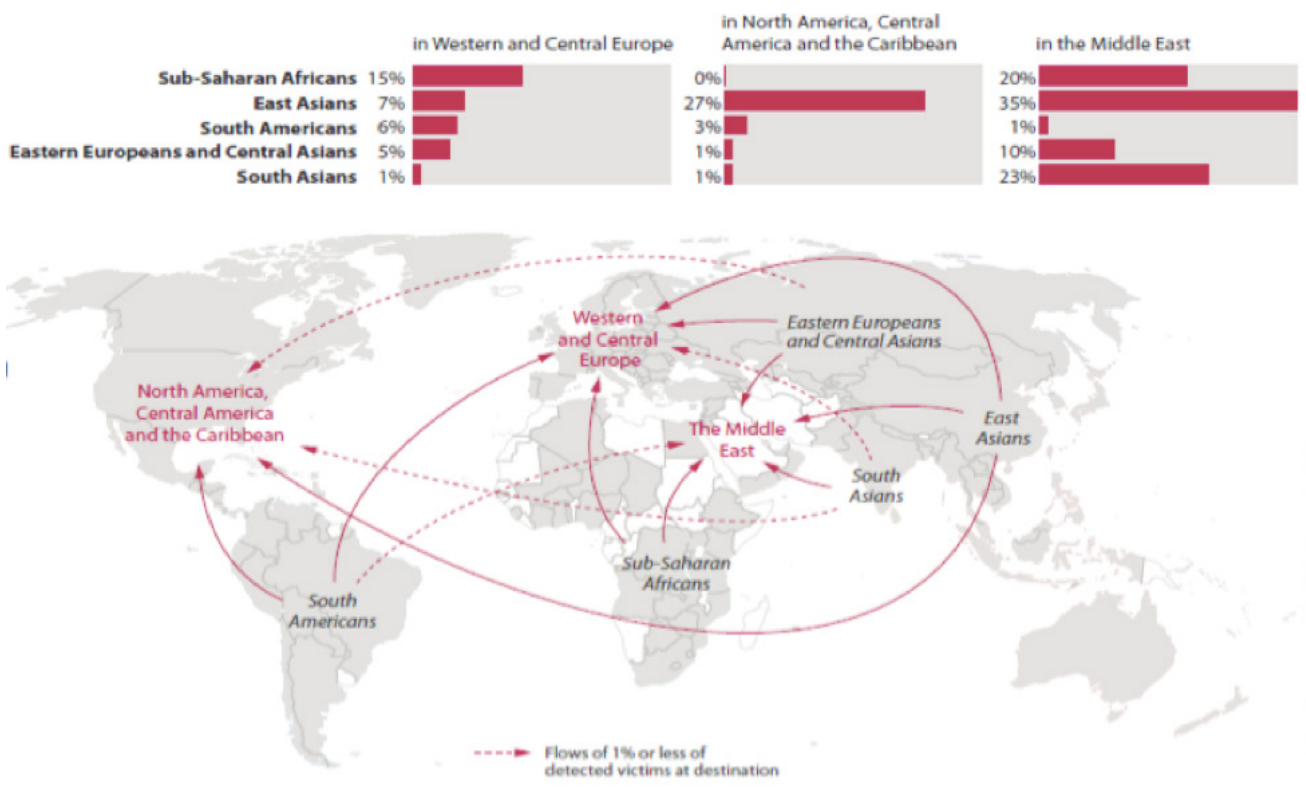

Figure 1: Transnational Flow of Destination and Source Countries

15 Ibid.

${ }^{16}$ Ibid.

17 Mickelwait, Laila. City in Focus: Los Angeles. 2014. http://exoduscry.com/prayer/cityin-focus/los-angeles/.National Security Council. "Transnational organized crime: a growing threat to national and international security."

${ }^{18}$ Global Financial Integrity. "Transnational crime in the developing world." 2011. http:// www.gfintegrity.org/storage/gfip/documents/reports/transcrime/gfi_transnational_crime_ web.pdf. 
In 2014, 1,350 cases of sex trafficking involved minors. The Polaris Project estimates the average age of entry into child exploitation, or child sex trafficking, is 12 to 14 years of age. ${ }^{19}$ In particular, homeless youth and runaways are especially at-risk. According to the National Human Trafficking Resource Center (NHTRC), $56 \%$ of prostituted women, including those that were trafficked, were initially runaway youth. ${ }^{20}$ Traffickers prey upon youth using social media, after-school programs, shopping malls, bus depots, and friends or acquaintances. ${ }^{21}$

\section{Conditions}

The prevalence of sex trafficking is widely contributed to the demand for sexual services; without a demand, supplies are not necessary. Demand stems widely from an overly sexualized culture, where objectification of women and girls is normalized. Society is so excessively stimulated with sex that even Playboy made a decision to remove all pornographic images and videos from its production. Their reasoning, "you're now one click away from every sex act imaginable for free. And it's just passe at this juncture."22 In particular, porn creates an unrealistic perception of sex. A recent study shows that men who are frequent users of porn are also frequent users of prostitutes. ${ }^{23}$ Indeed, 80 percent of clients show pornographic images or videos to prostitutes, asking for the same service(s). ${ }^{24}$ Sex trafficking is the most common form of human trafficking, accounting for 79 percent, and the victims are predominately women and girls. ${ }^{25}$ Objectification of the female body, and the exponentially growing availability to act-out such objectification has increased the hypersexuality of many cultures and societies, and has undoubtedly spawned a demand for sex; traffickers have taken the fiscal opportunity to meet such demands. On the supply side, victims are often already victimized through abusive family environments or have endured prior sexual

\footnotetext{
19 Op. Cit., fn. 4

${ }^{20}$ National Human Trafficking Resource Center. "The Victims.” Trafficking Resource Center. 2015. http://www.traffickingresourcecenter.org/what-human-trafficking/human-trafficking/victims?gclid=CKbP5IHz7cgCFYM6gQodEKkMZg.

${ }^{21}$ Op. Cit., fn. 6

22 Somaiya, R. Nudes are old news at Playboy. October 12, 2015.

${ }^{23}$ Farley, M, and V. Vol 11 (4): 29-64. Kelly. "Prostitution: A critical review of the medical and social science literature." Women and Criminal Justice 11, no. 4 (2000): 29-64.

${ }^{24}$ Op. Cit., fn. 6

25 Op. Cit., fn. 14
} 
abuse. ${ }^{26}$ This makes such individuals significantly more vulnerable to the deceptive and coercive methods used by traffickers to control victims. As illustrated in Figure 2, traffickers use techniques within the power and control spectrum to successfully manipulate and therefore exploit individuals. Understanding, in-depth, the psychological trauma of such tactics influences stakeholders, specifically service providers, on how to meet the needs of victims. Such knowledge also serves in enlightening stakeholders to the link between sex trafficking and prostitution, as the same tactics affect victims of sex trafficking as well as prostituted individuals. ${ }^{27}$

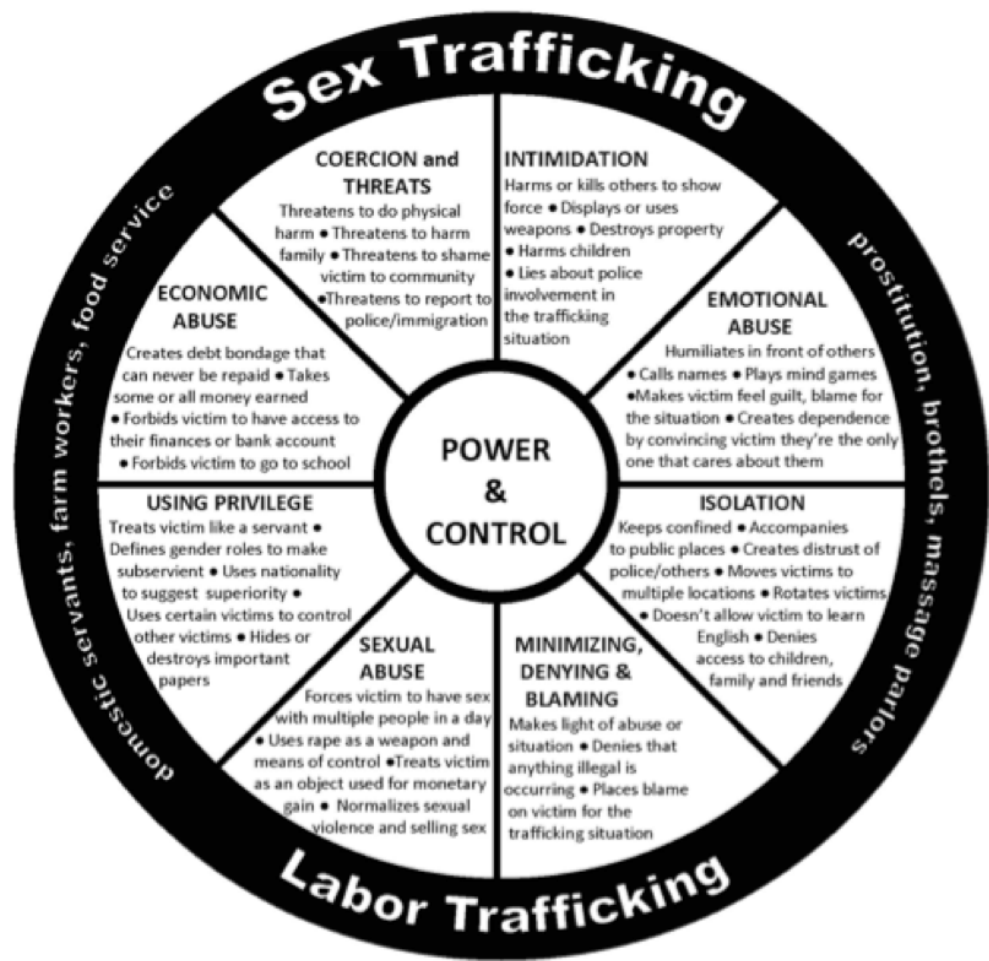

Figure 2: Power and Control Spectrum

${ }^{26}$ Op. Cit., fn. 20

${ }^{27}$ Farley, M. "Prostitution and trafficking in nine countries: An update on violence and posttraumatic stress disorder." Prostitution Research. 2003. http://www.prostitutionresearch. com/pdf/Prostitutionin9Countries.pdf. 
Technology, especially advancements in transportation, provides a strong bridge between supply and demand, making it easier for traffickers to meet the demands of clients. According to Exodus Cry, "with a simple click of a button or tap on a screen, today's pornography can be accessed anytime, anywhere, and for any price, even for free." ${ }^{28}$ Traffickers can now rely on advertising the available services of victims online through specialized websites, as well as, prominent sites such as BackPage and Craigslist. ${ }^{29}$ In many cases Social Media is used to reach out to youth to exploit weaknesses, such as family issues and insecurities that are often expressed on Social Media sites. ${ }^{30}$ Technology has also made it possible for traffickers to identify smuggling routes, leverage communication networks, share bank accounts, and make wire transfers, all in an effort to increase business. ${ }^{31}$ Traffickers can now use modern transportation, airplanes, vehicles, and trains, to easily transfer victims from source nations to destination nations. ${ }^{32}$ Displacement of an individual aids in a traffickers ability to control victims. When a victim is transported to a foreign nation with foreign language, customs, and culture, it creates a forced dependence on the trafficker. ${ }^{33}$ Additionally, traffickers easily move victims from one location to another to avoid interference with law enforcement. ${ }^{34}$

\section{Alternatives}

Of the most effective approaches to dealing with the issue of sex trafficking, the Nordic, or Swedish, Model has shown substantial results in reducing prostitution of individuals, and therefore reducing trafficking. The Nordic Model, in comparison to legalizing the industry of prostitution and decriminalization of clients, shows results in decreasing the issue of sex trafficking. Countries with the legalization approach, such as the Netherlands, have

\footnotetext{
${ }^{28}$ Op. Cit., fn. 17

29 U.S Department of State. "Trafficking in persons report." U.S Department of State. 2015. http://www.state.gov/j/tip/rls/tiprpt/.

${ }^{30}$ Op. Cit., fn. 6

${ }^{31}$ Ibid.

32 Ibid.

33 Ibid.

${ }^{34}$ Op. Cit., fn. 20
} 
higher rates of sex trafficking. ${ }^{35}$ In Sweden, the Nordic Model deters traffickers, as clientele is almost non-existent. Similarly, Las Vegas, Nevada, known for its legalization of the prostitution industry, recovered 2,229 victims of sex trafficking over the last decade. ${ }^{36}$ Legalizing the industry of prostitution does not prevent trafficking; it increases it, and therefore is not a viable solution.

The progressive model decriminalizes prostituted individuals, as a majority of prostituted individuals are also sex trafficking victims, enduring the same trauma, psychological manipulation, and physical abuse. In addition the model criminalizes johns and pimps, and promotes the value of women to subdue the objectification of females. Victimized individuals even receive resources and assistance from governmental and non-governmental agencies towards reducing recidivism back into the industry. Since its enactment in 1999, Sweden's number of prostitutes decreased significantly from about 3000 to an estimated 200 individuals. ${ }^{37}$ Other countries such as Denmark, Finland, Iceland, Norway, and Canada are experiencing similar results since the enactment of laws similar to the Swedish Model..$^{38}$ In Sweden, sex-buyers risk their careers and families, as prosecuted individuals incur fines, and or up to a year in prison. The Nordic Model altered behavior of male sex buyers, by decreasing purchase of sexual services from 13.6 percent to 7.9 percent. ${ }^{39}$

Such a model, if implemented within the United States, would deter buyers from engaging in sexual acts and therefore decrease the demand for sexual exploitation and sex trafficking. For undeterred individuals, prosecution with fines and or a prison sentence will increasingly prevent them from obtaining sexual services and defeat any future endeavors. Low demand will also deter traffickers from exploiting vulnerable individuals, and thus increase public and child safety. Promoting a culture in which women are not objectified will result in less porn use and therefore a decrease in hypersexuality. A decrease of hypersexuality, and therefore demand, from a large source of consumed

${ }^{35}$ ReThink Life. Prostitution in Canada. June 4, 2014. http://www.rethinklife.org/blog/category/prostitution.Shryock, Kathleen. "City in Focus: Las Vegas, Nevada." Exodus Cry. 2014. https://exoduscry.com/prayer/city-in-focus/las-vegas-nevada/.

36 Shryock, Kathleen. "City in Focus: Las Vegas, Nevada.” Exodus Cry. 2014. https://exoduscry.com/prayer/city-in-focus/las-vegas-nevada/.

${ }^{37}$ Op. Cit., fn. 7

38 Op. Cit., fn. 7

39 Op. Cit., fn. 7 
sexual services, will ultimately reduce transnational crime, in relationship to sex trafficking.

In addition to the cultural and legal aspects of the Nordic Model, its priority to supply resources for victimized individuals includes an increase in the current funds provided to governmental and non-governmental organizations. The Trafficking Victims Protection Act, which already allocates funds to specific entities involved in anti-human trafficking work, in collaboration with the Nordic Model, would disperse resources to organizations implementing prevention, intervention, and restoration measures. ${ }^{40}$ Such resources would provide crucial services to victims, helping to reduce re-entry into trafficking. Additionally, it would empower individuals to re-integrate back into society successfully and provide them the means to become contributing members of society, as well as strong advocates in the crucial fight to eradicate sex trafficking.

${ }^{40}$ Polaris Project. Policy Advocacy: Current Federal Laws. 2014. http://www.polarisproject. org/what-we-do/policy-advocacy/national-policy/priority-legislation. 


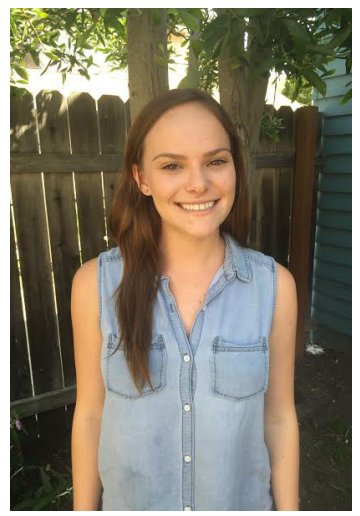

GINGER JACOBS is a graduating Political Science major with a concentration in Global Politics. She has greatly enjoyed her time in San Luis Obispo and is grateful for the mentorship of the political science faculty. While at Cal Poly, she spent a quarter studying in Florence, Italy, and a summer interning in the Senate in Washington, D.C. After graduation, she is moving to Washington, D.C., to join the staff of United States Senator Brian Schatz. Eventually she hopes to pursue a career in international development or foreign relations. 
EXAMINING CORPORATE POWER AT HOME AND ABROAD

Ginger Jacobs

\section{Real World Observation}

On March 25, 2015 Representative Mike Pompeo (R-KS) introduced the "Safe and Accurate Food Labeling Act." "The act proposes a new government certification for foods free of genetically modified ingredients, or GMOs. This government-certified label would allow companies that want to advertise their foods as GMO-free to do so. The certification would be completely voluntary. ${ }^{2}$ This proposal is an attempt by the agricultural biotechnology industry to head off recent efforts by states to make GMO labeling mandatory. If passed, Pompeo's bill, would override legislation that has been passed in Maine, Connecticut, and Vermont that require mandatory GMO labeling. While the laws in Maine and Connecticut depend on similar laws being passed in neighboring states, the Vermont labeling law is set to go into

\footnotetext{
${ }^{1}$ U.S. Congress. Rep. Pompeo, Mike. H.R. 1599. Safe and Accurate Food Labeling Act of 2015. $114^{\text {th }}$ Congress, (introduced March 25, 2015).

2 The Associate Press, "Bill Would Create Organic-Type Labels for Nonmodified Foods," The New York Times, March 242015.
} 
effect on July 1, 2016. ${ }^{3}$ The industry, which supports Pompeo, is dominated globally by a handful of agrichemical and seed companies, including Monsanto Co., DuPont Pioneer, Dow AgroSciences, and Syngenta. ${ }^{4}$ These companies strongly oppose the individual state efforts to make GMO labeling mandatory, saying that labels would be misleading because GMOs are safe and labeling them would make consumers believe otherwise. They also claim that inconsistent state laws would be confusing and costly for consumers and for companies. ${ }^{5}$

Since the commercialization of the world's first genetically engineered crops in 1996, there has been an ongoing debate globally about the safety and effectiveness of GMOs. ${ }^{6}$ While the topic has always been controversial, concerns about GMOs in the United States have historically been a marginalized issue. However, in recent years this has changed. Concern regarding the safety of GMOs has completely exploded in the US, making GMOs a household term and a mainstream issue. Consumers have taken it upon themselves to fight for and implement GMO legislation, as can be seen in Maine, Connecticut, and Vermont. In fact, GMO labeling bills have been proposed in some 20 states showing that these concerns are not dissipating. ${ }^{7}$ Previously the agricultural biotechnology industry went relatively unnoticed by the American public, but now the industry has a lot to lose. The introduction of the "Safe and Accurate Food Labeling Act" demonstrates that the industry recognizes this, and it is their attempt to nationally undermine the legal efforts that individuals have taken in their states. They are fighting back, and they are winning. So far the corporations have been successful in fully protecting their interests by delaying or nullifying GMO-related legislation through lawsuits and now the proposal of this act, despite the fact that the people American people have already voted.

The "Safe and Accurate Food Labeling Act" represents a power struggle

\footnotetext{
${ }^{3}$ Ibid.

4 Thompson Megan, "GMO seeds grow into big fight on Kauai," PBS NEWHOUR, December 23, 2013.
}

5 Op. Cit., fn. 2

${ }^{6}$ REUTERS, "Factbox: GMO Crops Have History of Controversy," The New York Times, October 292014.

7 Amy Harmon, "A Lonely Quest for Facts on Genetically Modified Crops," The New York Times, January 4, 2014. 
between people and corporations, a power struggle that has a long tradition in the global political arena. Historically, sometimes the people's interests have prevailed, and sometimes the corporations' interests have prevailed. Resulting in a general equilibrium between the two groups' authority and influence. Corporations have always held power, but democratic institutions have traditionally been able to implement legislation that reflects the people's convictions and demands. However, as we can see, corporations are gaining power and influence both domestically and internationally. New trade laws of the $21^{\text {st }}$ century dramatically increase the authority of international corporations. Such acts suggest a shift in the distribution of power between people's democratic capabilities and corporate prerogatives on a global scale. Leading me to ask the research question: How are corporations increasingly overriding democratic legislation at home and abroad?

\section{Conventional Wisdom}

The conventional wisdom holds that many people believe that corporations enjoy too much power. According to a Gallup survey from January 2013, 70\% of Democrats were very or somewhat dissatisfied with the size and influence of major corporations, and $51 \%$ of Republicans were very or somewhat dissatisfied with the size and influence of major corporations. ${ }^{8}$ A similar poll by Pew Research Center shows there is public agreement that the U.S. economic system unfairly favors powerful interests, and even more Americans believe that large corporations in this country are too powerful. The study showed that $78 \%$ of people think too much power is concentrated in the hands of a few large companies. An additional study showed that $67 \%$ of people say government policies have helped large corporations at least a fair amount. ${ }^{9}$

Based on these non-partisan public opinion polls, the conventional wisdom on corporate power is incomplete. My research question challenges conventional wisdom because while the layman's view does think that corporations hold too much power, it does not take into account the bigger picture of how these corporations are gaining so much legal authority in democratic societies. The fact of the matter is that even with growing corporations, most

\footnotetext{
8 Saad, Lydia, "Americans Decry Power of Lobbyists, Corporations, Banks, Feds," Gallup, April 112011.

9 "Fairness of the Economic System, Views of the Poor and the Social Safety Net," Pew Research Center U.S. Politics \& Policy, June 262014.
} 
people tend to think of states as the primary actors. However, states are increasingly handing over authority to corporations, giving them power to challenge domestic law. For example, corporations are receiving increasing authority through new trade laws in the $21^{\text {st }}$ century. This is in the state's interest in part because it takes responsibility out of state's hands. For example if Monsanto wins a lawsuit against a county or farmer, American politicians can say they did everything in their power but that the case was simply not in their control. The public has yet to realize the extent of power that corporations hold today, and how it is affecting the democratic process., Finally, the public is largely unaware of the state's active participation in the process.

\section{Methodology}

I utilize qualitative methodology in order to examine my research question. I use three case studies to explain how corporations are gaining authority at home and abroad. The first case study addresses the role of corporations domestically, with GMO movements in Hawaii and California. My second case study looks at the role of corporations through international trade agreements, specifically the Investor State Dispute Settlement by examining the role of tobacco industry leader Philip Morris in it's current legal dispute with Australia and Uruguay. My third and final case addresses corporation's relationships with states and the WTO, through the WTO Tuna Dispute: Mexico v United States. My research findings are based on primary sources such as nonpartisan public polls, hearing transcripts, and state and federal documents. I also use a wide range of secondary sources including articles from the New York Times, the Wall Street Journal, Forbes, and more.

\section{Theoretical Paradigms}

The theoretical paradigm of Marxism best frames and explains the answer to my research question. Founded by Karl Marx, Marxism states that society is based upon the material exchange of capital. Marxism's primary assumption is that capitalism is exploitative. This assumption helps to explain the actions taken by corporations in my research findings. Marx argued that change has to be system-driven, providing an explanation for why people's attempts at combating corporate power, as can be seen in my research, is relatively unsuccessful.

Leo Panitch's concept of a non-territorial empire provides an additional ideology to further frame and explain my research. Panitch, like Marx, focuses 
on the spread of capitalism. He sees globalization as a form of informal imperialism by capitalist states. He argues that the process of globalization is being led specifically by America through organizations such at the Federal Reserve of the World Bank. Panitch says that this non-territorial empire was consciously planned and managed by states, and furthermore that multinational corporations have power in the world order because that power is given to them by capitalist states. ${ }^{10}$

\section{GMO Cases in Hawaii and California}

Large biotech companies like Syngenta, Monsanto, Pioneer, Dow and BASF have long been experimenting with GMO crops and seeds in Hawaii. These companies use Hawaii to produce genetically engineered seed for mainland farmers as well as conduct research on new strains. While it may seem odd for a place blossoming with exotic fruits to focus on plant a mostly associated with America's Midwest, without seasonal interruptions, research can be accelerated by three or four fold. Mark Phillipson, who works for Syngenta, and is the president of Hawaii's seed trade group, recently reiterated this. He said "Something that would take- ten-to-12 years to develop, we can do here in three-to-four years." 11

Today, the seed industry is now the state's largest in the agriculture sector, reaching a value of $\$ 243$ million, double of what it was six or seven years ago and worth more than triple the second-largest commodity, sugar. Currently operations exist on Maui, Kauai, Oahu and Molokai. The industry employs 1,397 people in the state. In 2010, these companies, which own or lease 25,000 acres, exported 9.7 million pounds of seed from the islands, almost all of it corn. Corn is used for many purposes in the US, including in the production of high-fructose corn syrup and cattle feed. ${ }^{12}$ Corn makes up 95 percent of the seed produced in Hawaii. ${ }^{13}$ In total, Hawaii has received more permits for field trials, with 2,996, than any other state, making it one of

\footnotetext{
${ }^{10}$ Leo Panitch, “The New Imperial State," (accessed Jun 9, 2015).

${ }^{11}$ Op. Cit., fn. 4

${ }_{12}$ Tom Callis, “GMO: \$243 million seed industry largest in state's ag sector," West Hawaii

Today, June 9, 2013.

13 Op. Cit., fn. 4
} 
the major centers for genetic research. ${ }^{14}$ There's nowhere in the world like it, given its combination of climate and familiar laws, said Cindy Goldstein, the outreach manager for Pioneer Hi-Bred International, the seed firm owned by Dupont Co., which has operated in the state since 1968. The familiar laws, Goldstein mentions is partially in reference to patent laws. ${ }^{15}$ Working in the U.S., instead of a warm place in another country, allows companies to develop seeds under strong U.S. patent law protections. ${ }^{16}$

Along with the rest of the country, the people of Hawaii have become more and more aware of the presence of GMOs, and because of Hawaii's importance to the GMO industry, the islands have become the center of this battle. In the past few years, not just one, but three Hawaiian counties have proposed anti-GMO legislation The latest initiative has been passed by Maui. The initiative was originally introduced by, the Sustainable Hawaiian Agriculture for the Keiki and the Aina movement, or SHAKA, who successfully gathered 18,000 signatures for the initiatives introduction on the ballot. ${ }^{17}$

In the course of the intense campaign, corporate giants outspent supporters by a ratio of 87 to 1 . In support of the bill the total amount raised from Committees or PACS was $\$ 64,780$, with the top donors being individual Hawaii residents. SHAKA also raised $\$ 70,000$ through a crowd funding campaign online. In opposition, the Citizens Against the Maui County Farming Ban, raised $\$ 7,896,164$. The top three donors were Monsanto, Dow Agro Sciences, and the Council for Biotechnology information. ${ }^{18}$ The money raised is along the lines of how much seed companies have been spending to battle GMO-related ballot initiatives across the country, but is unheard-of in Hawaii politics. The amount of money that was raised by these corporations comes out to more than $\$ 90$ per registered voter in Maui County, which has a population of just 160,000.Reports filed with the Federal Communications Commission show that corporations had contracts for more

\footnotetext{
14 Op. Cit., fn. 12

15 Paul Voosen, "King Corn Takes Root in Hawaii," The New York Times, August 22, 2011.

${ }^{16}$ Robynne Boyd, "Genetically Modified Hawaii," Scientific American, December 8, 2008.

${ }^{17}$ Audrey, McAvoy, "Maui Votes To Temporarily Ban Growing of GMO Crops," The Huffington Post, November 4, 2014.

18 "Maui County Genetically Modified Organism Moratorium Initiative (November 2014)”, BALLOTPEDIA.
} 
than $\$ 1.3$ million worth of TV spots. That makes the Maui County initiative among the top 20 most expensive ballot measures in the nation for spending on TV advertising, according to an analysis of statewide ballot initiatives by the Center for Public Integrity. ${ }^{19}$ One of the group's TV spots features a senior citizens' club president warning of hundreds of job losses. Another shows a former county councilwoman discussing the financial burden the county would shoulder to enforce any moratorium.

Despite, the massive campaigning and spending by these corporations, the citizens of Hawaii celebrated a huge victory when the GMO initiative was passed by $51.9 \%$, with 23,082 votes voting in favor of the initiative and 22,005 votes against the initiative. ${ }^{20}$ The initiative temporarily bans the farming of GMO crops in Maui County until the county conducts an analysis of the health effects of genetically modified farming and foods. Under this law, the moratorium would be lifted only after a vote by the Maui County Council. The law, which doesn't apply to crops in mid-growth cycle, was supposed to go into effect when officials certified the election results.

Recently, Kauai and Hawaii county councils passed similar GMO bans, however shortly after the bans passed the same agricultural biotech corporations sued the perspective counties, and consequently a federal judge, Judge Barry Kurren, overturned them both. Having carefully studied this, the SHAKA Movement - along with the five citizens - immediately filed legal action. The SHAKA Movement's legal council asked the State judge to order Maui County officials to proceed forward in properly implementing the GMO Moratorium Bill. ${ }^{21}$ "The people of Maui passed this law through the proper ballot initiative power; the county attorneys, as public servants, have a duty to defend it," said George Kimbrell, attorney with Center for Food Safety, in a press release. The following day, as predicted, Monsanto Co. and a Dow Chemical Co. filed a lawsuit in federal court in Honolulu, asking a judge to immediately prevent the law from taking effect and to invalidate the measure. "This local referendum interferes with and conflicts

19 Liz Whyte, “Corporations, Advocacy Groups Spend Big on Ballot Measures, "Center for Public Integrity, October 23, 2014.

${ }^{20}$ Hawaii Secretary of State. Final Summary Report. "General Election 2014-State of Hawaii-County of Maui".

21 Op. Cit., fn. 18 
with long-established state and federal laws that support both the safety and lawful cultivation of GMO plants" Jon Purcell, Monsanto Hawaii's business and technology lead, said in a statement. ${ }^{22}$

The federal judge assigned to the case, U.S. District Court Chief Judge Susan Mollway, granted the corporations a preliminary injunction, preventing the GMO initiative from taking effect until the court considers its legal merits further. The injunction was originally supposed to be lifted on March 31. Mollway then pushed back the next hearing of the motions of the case to June 15, 2015. Mollway based her decision to further delaying the implementation of the moratorium on two bills introduced in the legislature this session that sought to block counties from regulating agriculture. Both bills are effectively dead this year but she noted that the issue could still resurface. The SHAKA Movement and the people of Hawaii are outraged. ${ }^{23}$

Despite Kauai, Hawaii, and Maui County passing legislation to ban GMOs in their counties in the last few years, none of them have been implemented. In each case as soon as the county passed the bill, the biotech industry leaders sued each county, and the cases got sent to federal court. County councils passed the Kauai and Hawaii county cases, but the Maui initiative was put on the ballot by the people, and voted by people despite massive campaigns from the corporations. Yet, so far there is nothing to show for the people's votes. Through lawsuits these corporations have managed to delay or nullify the legislation despite the fact that people have clearly expressed their opinion on the matter. In fact, the majority of the country sides with the people of Hawaii, in a 2013 New York Times poll, three-quarters of Americans surveyed expressed concern about G.M.O.s in their food. ${ }^{24}$ As one of the center of GMO experiments in the world, they are worried about the wellbeing of their health and environment. Additionally, they are frustrated that exercising the correct democratic processes has yet to successfully challenge the massive corporate presence on their islands. While hopefully on June 15 Mollway decides to uphold the people's wishes, given the history of the Judges decision in the Kauai and Hawaii cases it seems highly unlikely.

\footnotetext{
${ }^{22}$ Ibid.

${ }^{23}$ Op. Cit., fn. 7

${ }^{24}$ Amy Harmon, "A Lonely Quest for Facts on Genetically Modified Crops," The New York Times, January 4, 2014.
} 
Most likely, the legal system will handover another win to the agricultural biotech industry.

However, the fact that people of Maui were able to unite against the large corporations and even pass the initiative is an accomplishment in it's own right. GMO labeling legislation that was proposed in California, Colorado, Oregon, and Washington were all defeated due to massive outspending by corporations on campaigns. Prop 37 in California was relatively close but the initiative was beat with $51.4 \%$ of people voting against it. There were $6,442,371$ votes against the proposition, and 6,088,714 votes for it. As of November 3, 2012, about $\$ 45.6$ million had been donated to the "No on 37" campaign effort. The top three donors for the "no campaign" were Monsanto donating $\$ 8,112,867$, Dupont donating $\$ 5,400,00$, and Pepsico Inc. donating $\$ 2,145,400 .{ }^{25}$ Other donors included the Grocery Manufacturers Association, Dow, Bayer, and more.

Jayson L. Lusk and Brandon R. McFadden from Oklahoma State University conducted a survey in 2012 of 822 likely voters of which $76.8 \%$ intended to vote in favor of Proposition 37. The study found that the possible increases in food prices slightly diminished support. ${ }^{26}$ Additionally, the study measured the effect of advertisements used in media campaigns by supporters and opponents of the proposition and found that the opponent's advertisement was more effective in swaying likely voters. Another poll by USC Dornsife and the Los Angeles Times showed similar results. According to the study, just from October to September, there was a 17-point drop in support of the proposition. ${ }^{27}$

Monsanto and its allies have fought the labeling of genetically modified vigorously since 1992, when the industry managed to persuade the Food and Drug Administration that the new crops were "substantially equivalent" to the old and so they did not need to be labeled, much less regulated. This represented a breathtaking exercise of both political power (the F.D.A. policy was co-written by a lawyer whose former firm worked for Monsanto) and

\footnotetext{
${ }^{25}$ California Proposition 37, Mandatory Labeling of Genetically Engineered Food (2012), BALLOTPEDIA.

${ }^{26}$ Ibid.

27 Suzanne Wu, "Support Slips for Ballot Measure to Require Labeling of Genetically Modified Foods," USCDornsife, October 25, 2012.
} 
product positioning. These new crops were revolutionary enough to deserve patent protection and government support, yet at the same time the food made from them was no different than it ever was, so did not need to be labeled. It is worth noting that ours was one of only a very few governments ever sold on this convenient reasoning: more than 60 other countries have seen fit to label genetically modified food, including those in the European Union, Japan, Russia and China. ${ }^{28}$ This time was no different The corporation won again in California, and they didn't even have to file lawsuits as they did in Hawaii, because their money altered the vote before people even cast their ballots.

\section{Philip Morris v. Australia and Uruguay}

Australia became the first nation in the world to require "plain packaging" for tobacco. The new laws require cigarettes to be sold in olive green packs without trademarks and with graphic health warnings. They were set to be introduced in December 2011, but were put on hold after the major tobacco companies including British American Tobacco, Philip Morris, Imperial Tobacco and Japan Tobacco challenged the new plain packaging legislation in Australia's domestic court. The companies argued the government was trying to acquire their intellectual property, including trademarks, without proper compensation. ${ }^{29}$ However, the government argued that it was only trying to regulate what appears on the boxes, after studies by the World Health Organization showed that plain packaging discourages smoking, especially in adolescents. ${ }^{30}$ On August 15, 2012 Australia's High Court ruled that the plain packaging law did not result in an unconstitutional acquisition of property and was justified as a public health measure. The court even ordered that the Tobacco companies pay for Australia's legal costs. Attorney General Nicola Roxon said in a statement addressing the Australian victory, "The message to the rest of the world is big tobacco can be taken on and beaten." Australia has been lauded by the World Health Organization as a leading public health example for other countries to follow. The New

\footnotetext{
${ }^{28}$ Michael Pollan, "Vote for the Dinner Party," The New York Times Magazine, October 10, 2012.

29 "High Court rejects plain packaging challenge," $A B C$ NEWS, August 14, 2012.

30 "Australia’s plain packaging laws successful, studies show," ABC NEWS March 18, 2015.
} 
York Times reports the plain packaging law is popular, with 59 percent of Australians approving. ${ }^{31}$ Meanwhile, a Hong Kong subsidiary of Philip Morris launched an investor-state case under the 1993 Australia-Hong Kong BIT. ${ }^{32}$ This is the first investor-state dispute that has ever been brought against Australia. Phillip-Morris has not yet specified the amount of compensation it is demanding from the government, but Philip Morris spokeswoman, Anne Edwards said, "we would anticipate that the compensation would amount to billions." ${ }^{33}$ In the lawsuit, Phillip Morris is arguing that plain packaging constitutes an expropriation of its Australian investments, that Australia is in breach of its commitment to accord fair and equitable treatment to Philip Morris, and that plain packaging constitutes an unreasonable and discriminatory measure. Furthermore Philip Morris Asia claims that its investments have been deprived of the full protection and security that the Hong Kong Agreement is supposed to ensure them. In response, the Australian government denied that the plain packaging proposal breaks any laws and said it would not back down. ${ }^{34}$

The arbitration is being conducted under the United Nations Commission on International Trade Law (UNCITRAL). UNCITRAL formulates and regulates international trade in cooperation with the World Trade Organization. The tribunal hearing the case is composed of three arbitrators, one appointed by Australia, one by Philip Morris, and one by the Secretary-General of the Permanent Court of Arbitration, this arbitrator acts as the presiding arbitrator. ${ }^{35}$ The tribunal was created on May 15, 2012. At Philip Morris's request, the ongoing proceedings will be largely non-transparent, with public hearings prohibited and the public release of most documents left up to the discretion of each party. While Australia had argued for open hearings and transparent filings, Philip Morris refused, arguing that even releasing documents after

\footnotetext{
31 Matt Siegel, “Tobacco Companies Fight Australian Cigarette Bill,” June 27, 2011.

32 Australia Attorney-General. Notice of Arbitration. Australia/Hong Kong Agreement for the Promotion and Protection of Investments. Investor:Phillip Morris Asia Limited.

${ }^{33}$ Associated Press, "Philip Morris sues over Australian plans to ban logos from cigarette packets," June 27, 2011.

34 Australian Government. Attorney-General's Department. Tobacco plain packaging-investor-state arbitration.

35 Procedural Order No.1 6. Philip Morris Asia Limited and The Commonwealth of Australia. February 23, 2015.
} 
the conclusion of the arbitration "would be a time-consuming process with minimal gains for the public interest." 36 The case is currently pending.

However, Australia is not Philip Morris' only investor dispute case at the moment. A Swiss subsidiary of Philip Morris International launched a similar case against Uruguay in February 2010 under the Switzerland-Uruguay BIT from $1991 .{ }^{37}$ Uruguay also implemented a slate of antismoking measures that featured a requirement that packaging for tobacco products include large, graphic public health warnings. Currently, tobacco companies in Uruguay are required to cover $80 \%$ of the area of both faces with graphic warnings and $100 \%$ of one side panel with text warnings. The graphic pictures include, decaying teeth, premature babies and gruesome hospital scenes. Uruguay also said you couldn't have any variation of a single brand sold in any store. You could have Marlboro, but you couldn't have Marlboro Light or Marlboro Gold. They said terms, like "light" and "gold," deceive consumers into thinking that those types are healthier than the average cigarette. In the end, Philip Morris had to take seven of its 12 products off the shelves. ${ }^{38}$

In the investor case, Philip Morris is saying that the percentage of warning labels that are required on cigarette packs in Uruguay goes beyond what is reasonable to protect people from the harmful effects of smoking. The company says that the warning labels leave no space for legally protected trademarks and intellectual property, and the corporation is seeking compensation for lost profits. The corporation is seeking $\$ 25$ million from the tiny country of 3 million people. ${ }^{39}$ Keep in mind, Uruguay's GDP in 2013 was about $\$ 55.7$ billion, while Philip Morris' revenues the same year totaled around $\$ 80.2$ billion. ${ }^{40}$

Unlike Philip Morris, the people of Uruguay have reacted favorably to the Government's aggressive anti-tobacco campaign and strong regulation in recent years. Uruguay's University of the Republic, in collaboration with

\footnotetext{
36 “Case Studies: Investor-State Attacks on Public Interest Policies," Public Citizen.

37 Ibid.

38 "Phillip Morris Sues Uruguay Over Graphic Cigarette Packaging," NPR, September 15, 2014.

39 Ibid.

${ }^{40}$ Leon Kaye, "Philip Morris Sues Uruguay Over Anti-Smoking Campaign," TriplePundit, April 13, 2015.
} 
a professor from Massachusetts Institute of Technology, did a study that showed between 2005 and 2011 smoking has reduced at the rate of 4.3\% annually. Fewer pregnant women are smoking and the birth rate is reported to have gone up as a consequence. By 2012, this reduction meant that less than $20 \%$ of the population smoked. However, those who do smoke are doing so more intensely. Between 2005 and 2009, the average number of cigarettes smoked per day per smoker in Uruguay went up by three cigarettes a day. The increasing population is also favoring the expansion of the cigarette market in the country. ${ }^{41}$

This adds to the sense of urgency for Phillip Morris with respect to the Uruguayan cigarette market. While sales stagnate for tobacco companies in developed countries, they must expand their business abroad. The result is that the World Health Organization estimates that 70 percent of the 8.4 million deaths that will be attributed to tobacco use in 2020 will occur in developing countries. Additionally, Philip Morris likely saw Uruguay as an easy target. ${ }^{42}$ They wanted to make an example out of Uruguay and send a message to the world that it is not worth the legal costs to enact stricter tobacco laws. "The costs of defending these cases are enormous, so tobacco companies are trying to pick off lower-income countries that can't spend the money and political capital to defend themselves against industry," Ellen R. Shaffer, co-director of the Center for Policy Analysis. ${ }^{43}$ The case is expected to cost Uruguay up to $\$ 8$ million in legal fees alone. Instead of scaring Uruguay into backing down, this lawsuit has drawn the attention of major players in global health, civil society and philanthropy circles. This includes, former New York City Mayor Michael Bloomberg, whose group Bloomberg Philanthropies has donated large amounts of money to Uruguay to help pay its legal fees. ${ }^{44}$ The International Center for Settlement of Investment Disputes (ICSID), under the trade agreement between two countries, will settle the lawsuit by binding arbitration. In July 2013, the investor-state tribunal in this case ruled that it had jurisdiction over the case and it is now

\footnotetext{
41 Op. Cit., fn. 35

42 Op. Cit., fn. 37

43 Carey Biron, "Worldwide, Tobacco Regulators Monitoring Philip Morris Lawsuit Against Uruguay,” November 24, 2014.

${ }^{4}$ Op. Cit., fn. 35
} 
weighing the merits of the tobacco corporation's arguments. The Uruguayan government filed its formal defense, which reportedly runs to 500 pages but is not yet publicly available.

Regardless of the final outcomes in these cases, already the investor-state system has had a chilling effect on tobacco control policies. A host of developing countries, are scared of being dragged into painful and expensive international arbitration, and are in a state of 'policy freeze'. Additionally, in February 2013, New Zealand's Ministry of Health announced that the government planned to introduce its own plain packaging legislation, but that it would wait until the investor-state case against Australia and Uruguay is resolved. The United Kingdom also slowed down its plain packaging laws to see how these dispute plays out. ${ }^{45}$

The tobacco giant's lawsuits against Australia and Uruguay are key examples of the growing trend of multinational companies using trade agreements as mechanisms to circumvent national legislation, even legislation supported by the people and meant to protect public health. The investor-state dispute settlement (ISDS) system fundamentally shifts the balance of power among investors, states, and the general public, creating an enforceable global regime that formally prioritizes corporate rights over the right of governments to regulate (pc). Under, ISDS foreign corporations and investors have the same status as sovereign governments. These corporations are empowered to go around domestic courts and directly sue countries when they disagree with their policies. These cases are seen before tribunals, but the tribunals deciding are composed of three private attorneys, not only are they unaccountable to any electorate, but they are also paid a lot. Using these expansive rights, foreign corporations have increasingly used ISDS to attack a wide array of tobacco, climate, financial, mining, medicine, energy, pollution, water, labor, toxins, development and other non-trade domestic policies. The number of such cases has been soaring. While treaties with ISDS provisions have existed since the 1960s, just 50 known ISDS cases were launched in the regime's first three decades combined. In contrast, corporations have launched more than 50 ISDS claims in each of the last three years. And unlike the victory for the citizens of Australia in domestic court, many governments have lost these suits and have already paid corporations billions of dollars. There is

45 Op. Cit., fn. 34 
no limit to the amount of taxpayer money that the tribunal can order the government to pay the foreign corporation. Ecuador was ordered to pay Occidental Petroleum $\$ 2.3$ billion. ${ }^{46}$ Additionally, There is a trend of these corporations picking on developing countries. In total, over the past years at least 89 governments have responded to one or more investment treaty arbitration: 55 developing countries, 18 developed countries and 16 countries with economies in transition. ${ }^{47}$ The pending cases in Australia and Uruguay have mass amounts of public support against the corporations because they deal with the highly politicized issue of smoking and it's dangers. Because of this, it is likely that the tribunals will act in favor of the countries, but this won't always be the case. This level of corporate power needs to be addressed and questioned. Especially as ISDS provisions have recently been proposed in many international trade deals, including the suggested TransPacific Partnership.

\section{WTO Tuna Dispute: Mexico v United States}

If one looks at almost any can of tuna sold in the U.S. he or she will find a tiny stamp. For more than 20 years, that stamp has certified that no dolphins were harmed or killed when the tuna was caught. For nearly that long, Mexico and the U.S. have been fighting over that label. In the 1990s, the U.S. declared Mexico's tuna, dolphin-unsafe. As many as 100,000 dolphins a year were dying due to Mexico's large net fishing tactics that encircles the dolphin pods to get to the huge schools of tuna swimming below. But over the years, those numbers have dropped significantly. Fishermen now use techniques so the mammals can escape. They've banned night fishing. And all boats in Mexico's tuna fleet have independent observers onboard. Mexico says it's made great strides protecting dolphins and that the U.S. now unfairly blocks Mexican tuna from its markets. ${ }^{48}$ Specifically, Mexico contends that the way the US defines "dolphin safe" tuna unfairly restricts trade.

The United States definition of dolphin safe tuna requires the fish are caught without using a huge net, known as a purse seine net, to encircle

\footnotetext{
${ }^{46}$ Op. Cit., fn. 34

47 "Latest Developments in Investor-State Dispute Settlement," United Nations Conference on Trade and Development. N. 1 April 2012.

${ }^{48}$ Carrie Kahn, “Trade Dispute With Mexico Over 'Dolphin-Safe' Tuna Heats Up," NPR October 3, 2013.
} 
dolphins and that no dolphins are killed or seriously injured in the process. That is more restrictive than the internationally accepted definition, which does not mention the use of purse seine nets. The Mexico Fishing industry is the largest users of purse seine nets. Mexican officials want the U.S. government to broaden its dolphin-safe rules to embrace Mexico's long-standing fishing technique of chasing dolphins that swim above tuna in the eastern tropical Pacific Ocean and capturing the tuna in large encircling nets. ${ }^{49}$

Mexicans are not the only ones who say they're being judged more harshly than other fishermen in the world. The World Trade Organization agrees. It ruled the U.S. discriminates against Mexico and must open its markets to Mexican tuna, or face possible retaliatory trade sanctions. ${ }^{50}$ However, the U.S. still refuses to allow Mexican tuna with a dolphin safe label on store shelves. Mexico s is prepared to retaliate with trade sanctions on U.S. imports.

The California-based Earth Island Institute, which monitors the tuna industry to ensure it follows U.S. dolphin-safe practices, disputes the eco-friendliness of Mexico's fishing methods. Even if no dolphins are killed during the actual chasing and netting, some are wounded and later die from shark predation, says Mark Palmer, associate director of the institute's International Marine Mammal Project. He says Mexico should be treated differently than other fishermen since they refuse to give up a fishing practice that chases, harasses and kills more than a thousand dolphins every year. ${ }^{51}$ Over the last decade, the Earth Island Institute has become a de facto global regulator of the $\$ 2$ billion-a-year canned-tuna industry. Its 14 monitors track tuna fishermen worldwide for "dolphin safe" practices, and those who are caught with so much as one dolphin in their nets get taken off the Earth Island list of "certified" companies. Getting taken off the list can kill a tuna business.

Meanwhile in Mexico, several canneries have gone out of business and more than a third of the fishing fleet has been sold off due to not being considered "dolphin safe". Jose Carranza, owner of Mexico’s biggest tuna processor, Pescados Industrializados S.A., in the Pacific coast city of Mazatlan, says

\footnotetext{
${ }^{49}$ Tom Miles, "WTO Rules For Mexico in Tuna Dispute," BanderasNEWS, May 17, 2012.

${ }^{50}$ United States - Measures Concerning the Importation and Sale of Tuna and Tuna Products. World Trade Organization. Dispute DS381.

51 Tim Carman, "Tuna, meat labeling disputes highlight WTO control," The Washington Post, January 10, 2012.
} 
yearly sales to Europe have fallen from 90,000 tons in the late 1980s to less than 10,000 tons today because the buyers are afraid of Earth Island. Others see a more dire force at work. "Earth Island is an arm of StarKist to control the markets," says Carlos Hussong, president of Mexico's fishing-industry group. "This is a protection of the U.S. industry." StarKist and Earth Island say that's nonsense and write it off as a conspiracy theory. ${ }^{52}$

Even a change in U.S. trade policy will not alter the buying practices of the tuna industry, because the U.S. government is not the final authority here. "None of our companies would buy from anybody not on the Earth Island list," says David Burney, head of the U.S. Tuna Association. "We don't want any problems. Earth Island is powerful." Gavin Gibbons, spokesman for the National Fisheries Institute's Tuna Council, which represents three processors (Bumble Bee, StarKist and Chicken of the Sea) that collectively sell more than 80 percent of the canned and pouched tuna on the U.S. market, says that it American companies still would not buy Mexican Tuna even if it is deemed safe. Gibbons says, the companies these days buy mostly skipjack tuna, whose populations remain healthy, not the yellowfin caught by Mexican fleets in the eastern tropical Pacific. The other question facing the U.S. tuna industry is whether it would continue using the dolphin-safe label if it were revised to include the chasing-and-netting techniques.

US consumer rights group "Public Citizen" said the WTO decision dealt a major blow to consumers' ability to make informed decisions about their food". This latest ruling makes truth-in-labeling the latest casualty of socalled 'trade pacts,' which are more about pushing deregulation than actual trade," Todd Tucker, research director for Public Citizen's Global Trade Watch, said in a statement. "Members of Congress and the public should be very concerned that even voluntary standards can be deemed trade barriers." The Earth Island Institute reiterated this sentiment and said the WTO put trade above the environment with this decision.

On June 5, 2015 the WTO said it received notice from U.S. of an appeal on the WTO decision. The United States said it thought the WTO panel report in the case was based on an incorrect legal interpretation. ${ }^{53}$ Thus the

\footnotetext{
52 Newsweek Staff, “The Earth Island Rules," Newsweek, May 5, 2002.

53 REUTERS, “U.S. appeals part of WTO ruling on dolphin-safe tuna labels," June 5, 2015.
} 
debate continues. While the debate on whether the U.S. is discriminating against Mexico, and the debate on Mexican fishing techniques, are both fascinating within themselves, it is not the most significant aspect of this WTO dispute. The significance of this dispute is that this is not a dispute between the U.S. and Mexico. This dispute between the U.S. tuna industry and the Mexican tuna industry, and like all industries their interests. While a portion may lie in dolphin safety, more so lie in profit. The safe dolphin label promotes sales for the U.S. tuna industry, and including Mexican tuna in those sales would take away profit. The Mexican tuna industry is tired of being iced out by the big U.S. tuna companies and Earth Island. The bottom line is that even a dispute that appears to be a trade issue between states that is being arbitrated through an international organization, is yet another instance of industries discovering new avenues in which they can further their interests. In this case, the states are acting on behalf of the industries because a higher profit for the industry means a stimulated economy for the state. This case of industry and states working together to further their interests further examines the shift in power distribution today and the increased opportunity that industries have to achieve power and authority through international trade agreements.

\section{So What?}

The massive shift in power from people to corporations has alarming ramifications for world politics. Corporatio s ability to sue not only counties, but also countries, when the people's positions do not align with their corporate profit models has the ability to severely compromise democracy and sovereignty. Traditionally, it was the people who were placed with power within a democratic society. Each of my case studies had to do with a concern of public health: GMOs, tobacco, and tuna regulation. Each of these items are things that affect people. People consume them and experience the health ramifications of them, yet in each of my case studies people had no control over these issues despite their best efforts to advocate their opinions and beliefs. Monsanto and the agricultural biotechnology companies found ways to delay or nullify legislation, either through massive campaign spending, lawsuits, or the proposal of new acts. Philip Morris has managed to battle plain packaging legislation by utilizing BITs signed years ago by Australia and Uruguay. By signing those trade agreements, these states handed over 
this investor's right to Philip Morris, whether they realized it or not. The tuna industry in Mexico utilized both its state and the WTO to advance its agenda. Not only are people losing power and corporations gaining them, but states are often assisting the process.

Joseph Stiglitz of Columbia University describes this as 'the secret corporate takeover' of trade agreements. He continues by saying "In the future, if we discover that some other product causes health problems rather than facing lawsuits for the costs imposed on us, the manufacturer could sue governments for restraining them from killing more people." ${ }^{54}$ The truth is that this future is not far away. While this increase of lawsuits by corporations is a relatively new trend today, I worry, like Stiglitz, about the possibilities and opportunities that this opens up for corporations going forward, especially with the multitude of trade agreements that are currently being considered globally. The world is currently engaged in a great debate about corporate power and we stand at a unique moment in time where states can decide to continue to empower these corporations, or they can decide to reign them in and give the people back their voice.

${ }^{4}$ Joseph Stiglitz, “The Secret Corporate Takeover," Project Syndicate, May 13, 2015. 


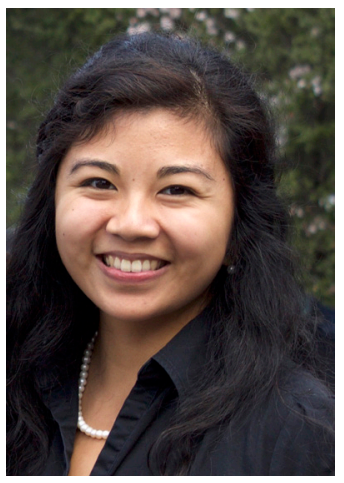

MICHELLE CRISTOBAL is a Financial Analyst for the Mozilla Corporation, the for-profit subsidiary of the Mozilla Foundation. She graduated from Cal Poly in 2008 with a degree in Political Science. 


\section{ALUMNI SPOTLIGHT}

\section{Michelle Cristobal}

Michelle Cristobal's first feeling toward Cal Poly was typical of most college students, nervousness. There was a large degree of uncertainty because this was the only in-state school she applied to, but those fears were quickly subdued. Now a financial analyst for the Mozilla Corporation, Michelle utilizes the critical-thinking and analysis tools she learned while at Cal Poly and in the Political Science department.

Coming to Cal Poly in 2006 as a Political Science major, Michelle appreciated the way her classes were taught. The Socratic-style teaching she experienced really opened up discussions and kept the professors down to earth. "The professors were at the same level as the students," she said. "Everyone had an equal responsibility for the class experience every day." Michelle also enjoyed the project-based structure to most of her classes, where Cal Poly's learn-by-doing motto shined through. Along with an American Politics concentration, Michelle took on psychology as a minor. This minor would come into play when it came to for her to choose a senior project, as she was able to focus on political psychology. She wanted to better understand the "people", and what governs the choices that are made every day. 
After college was when Michelle ran into most of her challenges. At first, her main goal was to attend law school right after graduation, but the 2008 economic crisis and the stories of even Ivy League law graduates having trouble finding work changed her mind. The other problem Michelle ran into was a lack of a professional network to help in her job search. "Other than the internships that I had, I didn't have influential connections or an influential network right out the gate," said Michelle. She wasn't discouraged, however, and started a career pivot by sending out many applications until she got a bite.

While at Cal Poly, Michelle worked for Campus Dining for four years in the procurement department, learning some of the ins-and-outs of logistics and finances. Once Michelle realized that a career change was needed, she used the experiences she had while working for Campus Dining in addition to political science skills to apply for jobs. Eventually she received a job offer from Anderson Audio Visual, and from then on things became less arduous. "It just got better from there, as soon as I got more experience," she said. After Anderson AV, Michelle moved to Avnet where she worked in procurement and customs regulations, overseeing the imports and exports of the company's goods and services. These experiences contributed to landing her current job as a Financial Analyst at Mozilla Corporation, where Michelle focuses on budgeting and forecasting for the marketing department and internal operations.

Michelle also had advice prepared for current students. She sees getting out into the "real world" early as incredibly helpful and something she wishes she had done more of. For the recently graduated, being stalwart and persistent is instrumental when trying to land interviews. She said, "There's nothing that can stop you when you're in person. As much as you can look good on paper, none of that is as compelling as just showing up." Finally, Michelle says to truly take advantage of Cal Poly's learn-by-doing approach. The experiences she had here stayed with her, and continue to help her even now. 


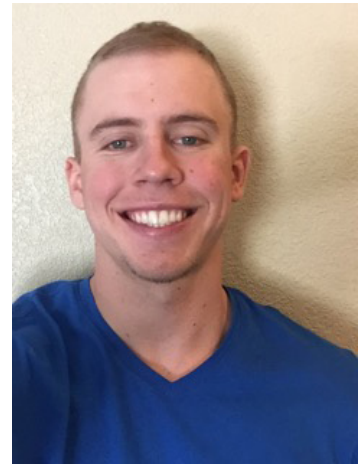

KEVIN DEELY graduated Cal Poly in Winter 2016 as a Political Science major with a concentration in Pre-Law. He came to Cal Poly after transferring from the College of Siskiyou in Lake Shasta where he played basketball. Kevin found his inspiration for this paper when he had the thought of moral luck as an idea that is very relatable to everyday life and considers himself to be extremely lucky in his life where he had escaped certain consequences. 


\title{
PUNISHING CRIMINAL ATTEMPTS: THE ROLE OF HARM IN CRIMINAL SENTENCING
}

Kevin Deely

\begin{abstract}
This paper is about how the severity of criminal punishment is often based on the resultant luck of the criminal. For example, a failed attempt at murder is punished with a lesser sentence than a successful attempt. Primarily, this paper dives into the various scholarly opinions regarding the role that "moral luck" plays in criminal sentencing. Moral luck essentially refers to the fact that society often makes moral judgments of people based on how a crime turns out, and not on the nature of the criminal attempt itself.

\section{Moral Luck}

One of the most controversial debates among philosophers has revolved around whether or not it is justifiable that our criminal justice system punishes failed criminal attempts less severely than successful criminal attempts. One of the reasons that this aspect of our legal system is so controversial is because many philosophers have insisted that the success or failure of a criminal action depends on factors that are beyond the criminal's control.
\end{abstract}


While our criminal justice system is commonly thought of as a reflection of humanity's moral values, it is reasonable to infer that humanity has a tendency to morally judge people on how their actions turn out. If one agrees with the position that criminals are not in control of the harm that they cause, it is reasonable to conclude that whether or not a criminal will be morally judged as good or bad is a matter of luck. Another controversial debate has revolved around whether or not a criminal who inflicts harm upon his victim is more morally blameworthy than a criminal fails to cause harm. These two controversial debates surrounding the punishment of criminal attempts have provided a wide range of philosophical arguments.

Thomas Nagel's "Moral Luck" is an essay that presents a platform for a bevy of philosophical arguments regarding the differential punishment of successful and failed criminal attempts. The purpose of this essay is to compare and contrast the opinions of five authors who have differing beliefs on punishment. Barbara Herman's "Feinberg on Luck and Failed Attempts" and Michael S. Moore's "Causation and Moral Blameworthiness" aim to justify our unequal punishment of successful and failed attempts. Sanford H. Kadish's "The Criminal Law and the Luck of the Draw" and Joel Feinberg's "Equal Punishment for Failed Attempts" aim to show that our legal system needs to be re-evaluated. David Lewis' "The Punishment that Leaves Something to Chance" aims to rationalize our current system of punishment, although Lewis admits that he is unsure if his rationalization is justifiable. Before I analyze what these five authors have to say, it is necessary to lay out the basis of Thomas Nagel's controversial argument.

Thomas Nagel suggests that Immanuel Kant's philosophy regarding luck's relationship to morality, which is that "good or bad luck should influence neither our moral judgment of a person and his actions, nor his moral assessment of himself," is often contrary to how society forms moral judgments. ${ }^{1}$ Nagel observes that although the success or failure of our actions often depends on many factors that are beyond our control, our actions are nevertheless preceded by a societal and self-reflective moral judgment that assesses our goodness or badness as people. Since much of what we do depends on factors that we have no control over, and we make moral judgments about

1 Nagel, Thomas. “Moral Luck.” Philosophy of Law. By Joel Feinberg, Jules L. Coleman, and Christopher Kutz. $9^{\text {th }}$ ed. (Boston: Wadsworth, 2014), 750. 
people anyway, "moral luck" can be described as the good or bad luck that comes from these uncontrollable factors and their effect on the subsequent assessment of our moral standing. While highlighting four kinds of moral luck, and simultaneously suggesting that we do not have control over our luck, Nagel's essay examines the paradoxical nature of moral luck and the dilemma it causes when trying to hold someone morally responsible for their actions.

Nagel insists that "what we do is limited by the opportunities and choices with which we are faced, and these are largely determined by factors beyond our control." 2 The absence of control that is inherent in our actions seems to make it impossible for us to hold anyone morally responsible for what they do. However, Nagel states that the condition of control cannot be ignored because it is simply a natural consequence of moral assessment. When we consider that one of the conditions of moral assessment involves observing the lack of control humans have over their actions, it becomes apparent that the idea of moral luck is paradoxical. It is paradoxical because although Nagel's intuition is that the absence of control rules out people being held morally responsible for most things, a man's moral standing will always come down to the lucky or unlucky nature of external influences that are beyond his control. Nagel suggests that although the absence of control seems to eliminate moral responsibility, society can still assess people as morally good or bad, as long as we accept that moral luck is a paradox. If society were to excuse everyone's actions as being the product of a lack of control, we would be unable to hold anyone morally responsible, which would be a major dilemma for society.

Nagel describes four kinds of luck that can influence our moral standing in society. The first kind of luck that Nagel discusses is "luck in the way one's actions and projects turn out," which is also commonly referred to resultant luck. ${ }^{3}$ As stated in Nagel's example, a drunk driver can be said to have received moral good luck if he swerves onto a sidewalk and there are no pedestrians. If there had been pedestrians on the sidewalk and he had killed them, we would view this man as morally worse than a drunk driver who simply crashed his car. The driver has no control over whether or not

\footnotetext{
2 Nagel, "Moral Luck." 751.

3 Nagel, "Moral Luck." 752.
} 
there are pedestrians present, so the vehicular manslaughter would be considered a case of bad moral luck for the man. Nagel also demonstrates luck in the way one's actions turn out by considering cases where decisions are made under uncertainty. For example, a rebel leader waging war against the government could not be morally assessed until we observed the results of his battle. If many of his people died and suffered, which is a consequence determined by uncontrollable luck, than we would assess him as morally bad. Nagel states that how things turn out tends to "influence culpability or esteem in a large class of unquestionably ethical cases ranging from negligence through political choice." ${ }^{4}$

The second kind of luck is constitutive luck, which Nagel describes as "luck in the kind of person you are," and luck in "your inclinations, capacities, and temperaments." Nagel states that our personal characteristics, such as being envious or conceited, are subject to moral condemnation even if these characteristics are "beyond the control of the will." In other words, even if we are sincerely motivated to control these impulses and cannot, people are often nevertheless morally "assessed for what they are like." While we can control our own will, we cannot control these traits and personal characteristics. Next, Nagel describes what he calls circumstantial luck. He describes this luck by stating that "things we are called upon to do, the moral tests we face, are importantly determined by factors beyond our control." ${ }^{8}$ For example, citizens of Germany who joined Hitler's regime during the Holocaust are judged as morally bad. Citizens of the United States may have joined the regime if they were in similar circumstances, but we do not morally judge them because they never had to make the choice, which is a matter of circumstantial luck. Lastly, Nagel describes "luck in how one is determined by antecedent circumstances." 9 Everything about what we do and who we are is determined by previous events and circumstances. Nagel points out that this fact theoretically makes it impossible to hold people responsible,

\footnotetext{
${ }^{4}$ Nagel, "Moral Luck." 753.

5 Nagel, "Moral Luck." 752.

${ }^{6}$ Nagel, "Moral Luck." 755.

7 Ibid.

${ }^{8}$ Ibid.

9 Nagel, "Moral Luck." 752.
} 
even for our evil motives and intentions, because who we are is dependent on previous circumstances that we have no control over. Nagel points out that this aspect of moral luck threatens to undermine all moral judgment, and this is why the concept of moral luck seems to make it difficult to hold people responsible.

Nagel states that the responsible self will disappear if all that is focused on is factors that are not in one's control. However, Nagel states that since humans cannot take an external view of themselves, we end up judging people as morally good or bad anyway, just as we would ourselves. Since focusing on the absence of control would alleviate all of human moral responsibility, we cannot operate from this view. Nagel introduces a complex philosophical problem for which he provides no solution. While stating that the human race often bases moral responsibility on factors that we have no control over, he seems to simultaneously conclude that our current legal system is unjust. While Nagel's essay examines the problematic paradox of moral luck, David Lewis provides an argument that aims to rationalize our legal system's way of punishing criminal attempts, while also acknowledging the existence of resultant luck.

David Lewis aims to articulate the nature of our current legal system without making it sound as if it is contradictory to the principle of proportional punishment, which states that the severity of a criminal's sentence should be in proportion to what he deserves. While Lewis concedes that it is unjust to punish failed attempts less severely than successful attempts, as both deserve equal punishment for their equally dangerous conduct, he suggests that the only way we can rationalize our current system is by making a case that we are punishing successful and failed attempts equally. Specifically, Lewis' essay is concerned with our judicial system's unequal punishment of murder and attempted murder. Lewis aims to justify our judicial system by suggesting that criminals metaphorically subject themselves to a penal lottery every time they attempt to murder their victims, and although whether or not the victim dies is a matter of resultant luck, our judicial system may be punishing all attempts equally because it is the criminal who has voluntarily subjected himself to varying levels of punishment.

Before Lewis explains his unique way of rationalizing punishment, he objects to a few other arguments that aim to accomplish the same goal. One rationale that Lewis addresses is that a criminal who successfully completes 
a crime deserves a more severe punishment simply because he is unlucky, which is an idea that invokes the debate of moral luck. In other words, while admitting that the difference between successful and failed attempts often comes down to luck in the way things turn out, this rationale insists that our justice system can cite luck as it's reasoning for differential punishment. Lewis states that resultant luck cannot be the factor that justifies differential treatment of successful and failed attempts, as we have no control over anything that occurs beyond the moment of our actions. Lewis insists that the luck involved in how our actions turn out has no bearing on how "the lucky and unlucky are," and makes no difference to "how they act." ${ }^{10}$ While Nagel suggests that the nature of our personality and the actions that we perform are matters of constitutive and circumstantial luck, Lewis states that we have control over who we are and how we act, and it is justifiable to punish someone accordingly. As this rationale cites luck as the primary reason for differential punishment, Lewis aims to find a rationale that can better justify our unequal punishment of attempts.

Another rationale that Lewis addresses insists that it is justifiable to punish successful attempts more severely because they require stronger whole-heartedness, as whole-hearted attempts require "stronger wicked desires," and subject the victim to greater risk because they are more likely to succeed. ${ }^{11}$ Lewis objects to this rationale because he does not believe that success can be the only measure of whole-heartedness, although he states that it is just to punish whole-hearted attempts more severely and to "proportion the punishment to the heartedness of the attempt."12 Lewis associates heartedness with the amount of risk that is inflicted on the victim of a crime. Lewis proposes a new rationale that he deems comparable to our present judicial system, in which successful attempts are punished more severely. He admits that it is most likely not just, but that it makes "at least a prima facie case" that our system is just. ${ }^{13}$

Lewis states that our current legal system can be compared to a "disguised

\footnotetext{
${ }^{10}$ Lewis, David. "The Punishment That Leaves Something to Chance." Philosophy \& Public Affairs 18.1 (1989): 56, accessed May, 2015, JSTOR.

${ }^{11}$ Lewis, "The Punishment That Leaves Something to Chance." 56.

${ }^{12}$ Lewis, "The Punishment That Leaves Something to Chance." 57.

${ }^{13}$ Lewis, "The Punishment That Leaves Something to Chance." 58.
} 
form of a penal lottery." ${ }^{14}$ A penal lottery is a hypothetical form of judicial process in which every man who attempts a crime is brought to court and subsequently "subjected to a risk of punitive harm." ${ }^{15}$ In this system, the court must decide if the defendant has knowingly and wrongfully subjected his victim to a risk of death. If the court finds that this is the case, the defendant is found guilty and is subjected to a lottery. After a guilty verdict, the court must determine how much risk the victim has been subjected to (a measure of heartedness), and the defendant's chances of winning the lottery are proportioned to the amount of risk he has inflicted on his victim. Whether or not the criminal is successful in his attempt, he will be sentenced to a lottery that leaves his punishment to chance. In this way, the lottery punishes successful attempts and failed attempts equally, because both criminals are sentenced to the same lottery.

Lewis insists that our current judicial system can be best characterized as an "impure" penal lottery, in which there is a guarantee of certain harm for both winners and losers. The winners of this lottery get a short prison sentence, while the losers are sentenced to death. In this system of punishment, it is known at once whether or not the defendant will win or lose if he is found guilty and sentenced to the lottery. The reason that the result of the lottery is immediately known is because the actual crime that has occurred serves as it's own way of determining the result. If the victim dies, the criminal will be sentenced to death. If the victim lives, the criminal will receive a short prison sentence. Therefore, the crime of attempted murder can be thought of as a penal lottery because whether or not the victim dies is a matter of chance. Since both successful and unsuccessful criminals face the prospect of punitive punishment, and both have subjected themselves to the same lottery, a case can be made that we are punishing them equally. The fact that we punish failed crimes less severely than completed crimes does not mean that an unsuccessful criminal should be described as less guilty, it just means that he has been fortunate in his resultant luck. Criminals subject themselves to a disguised form of a penal lottery every time they take the chance of inflicting varying levels of harm to their victims. Although the death of the victim is a matter of chance, the defendant is the one who has voluntarily

\footnotetext{
${ }^{14}$ Ibid.

15 Ibid.
} 
subjected the victim to this risk of death. Lewis' argument is that our current judicial system may be punishing attempts equally, as the criminal's chance of receiving severe punishment is proportional to the chance that he has taken while inflicting a risk of death upon his victim.

Although he presents an argument that aims to justify our current system of punishment, Lewis admits that he is on the fence about whether or not this aspect of our legal system is just. Sanford H. Kadish offers an argument that is far more opposed to unequal punishment for failed and successful criminal attempts.

Kadish's essay revolves around its criticism of the role that resultant luck plays in our punishment of criminal attempts. Kadish states that our current judicial system is in accord with the "harm doctrine," which is a doctrine that "reduces punishment for intentional wrongdoers if by chance the harm they intended or risked doesn't occur." ${ }^{16}$ Kadish acknowledges that humanity consistently factors in this resultant luck when we morally judge people and their actions, and that criminal law is essentially a reflection of humanity's moral viewpoints. Nevertheless, he states that the harm doctrine cannot be rationally defended, although "its adoption by the law" is rational because humanity's moral judgments are irrational. ${ }^{17}$ Although this essay acknowledges the paradox of moral luck, it is far more concerned with why the harm doctrine is not rationally defensible in terms of its application to criminal law. Kadish states that the harm doctrine is not rationally supportable because it "does not serve the crime preventive purposes of the criminal law," and because it cannot be supported by the any relevant principle of justice, as punishment's moral function is to sentence criminals based on what they deserve, and resultant luck has no influence on desert. ${ }^{18}$

Kadish argues that governing in accordance with the harm doctrine does not facilitate crime prevention because the doctrine does not aid in "preventing further acts by the offender" or "discouraging criminal acts by others." ${ }^{9}$

${ }^{16}$ Kadish, Sanford H. "The Criminal Law and the Luck of the Draw." The Journal of Criminal Law \& Criminology 84.4 (1994): 679, accessed May, 2015, Academic Search Premier [EBSCO].

17 Kadish, "The Criminal Law and the Luck of the Draw." 681.

18 Kadish, "The Criminal Law and the Luck of the Draw." 680.

19 Kadish, "The Criminal Law and the Luck of the Draw." 684. 
To begin his argument, Kadish articulates why he believes punishing failed attempts less severely does not help prevent further acts by the criminal. Kadish argues that in cases where the criminal has intentionally attempted to commit a crime, the actual occurrence of a harm is not relevant in assessing the criminal's dangerousness to society, and that punishment is supposed to be a "response to the threat" that criminals impose on society. ${ }^{20}$ Kadish exemplifies this argument by considering a case in which a man who is a given a short prison sentence for attempted murder has his sentence reversed to life in prison, simply based on the fact that the victim happened to die months later. The dangerousness of the man has been shown by his attempt to kill his victim, and the victim's death should not impact the man's prison sentence because it is a factor beyond his control. Kadish also states that resulting harm should have no bearing on criminal sentencing in cases of culpable risk creation. For example, a man who kills a person while playing Russian roulette is equally as dangerous as a man who, by luck, does not end up killing his victim. Kadish suggests that this is logic also applies to cases of impossibility, because the defendant's dangerousness to society has been exemplified despite the fact that a crime could not have possibly occurred.

Continuing his argument, Kadish addresses his statement that the harm doctrine does not aid in discouraging others from committing criminal acts. To develop his argument, Kadish deconstructs two possible arguments that suggest lesser punishment for failed attempts would actually aid in the general deterrence of crime. The first argument states that by punishing attempts less severely than completed crimes, "we do not lose deterrence, because people who try to commit a crime expect to succeed, and if the punishment for success does not deter them, an equal punishment for failure certainly will not." ${ }^{21}$ Kadish objects to this theory by arguing that in cases where a criminal knows there is a better chance of being caught and punished if he fails, as is the case during consensual narcotic sales, equally severe punishment for attempts would more effectively deter crime. The second possible argument states that "the harm doctrine would serve crime preventative purposes by offering the prospect of lesser punishment as an inducement for the defendant

\footnotetext{
20 Ibid.

${ }^{21}$ Kadish, "The Criminal Law and the Luck of the Draw." 686.
} 
to desist." 22 In response, Kadish states that this argument cannot be applied to cases of culpable risk creation, as it is too late to desist from an action once a risk is taken. Furthermore, Kadish states that in cases of attempt, this argument does not apply to criminals who believe that they have taken the last step towards completing a harm. Even for criminals who believe they have more to do, Kadish states that a change of heart is unlikely once they have committed themselves to a "substantial act towards carrying out the crime," a condition that is required in the law of attempts. ${ }^{23}$

As previously stated, the second element to Kadish's reasoning on why the harm doctrine is not rationally defensible is that it cannot be defended by a relevant principle of justice. Kadish suggests that the "principle of desert," which insists that punishment should be limited to "what the offender deserves," is not in accord with the harm doctrine. ${ }^{24}$ His reasoning is that criminals deserve to be punished based on the nature of their wrongful acts, and the resulting harm from a criminal act has no relevance to what the criminal deserves. Kadish raises a few possible arguments that attempt to justify the lesser punishment of failed attempts in terms of what the criminal deserves. The first argument that Kadish addresses is Lewis' concept of a penal lottery, which insists that a criminal deserves to be evaluated and punished based on what he has caused because he is the one who has voluntarily subjected his victim to a risk of death. Kadish rejects this concept because he cannot fathom how, in cases of an attempted killing, it is justifiable to leave the sentences of two equally deserving offenders to the chance of whether or not the victim dies or lives. The second argument that Kadish addresses suggests that one who succeeds at causing harm makes him a worse person. In response to this commonly held suggestion, Kadish states that the principle of proportional punishment requires that the severity of punishment should be proportional to the defendant's blameworthiness, not what he has "become in some existential sense," as the argument suggests. ${ }^{25}$ In other words, the blameworthiness of a defendant should be determined strictly based on the nature of his action. Lastly, Kadish addresses the retributive

\footnotetext{
${ }^{22}$ Kadish, "The Criminal Law and the Luck of the Draw." 687.

23 Ibid.

${ }^{24}$ Kadish, "The Criminal Law and the Luck of the Draw." 688.

25 Kadish, "The Criminal Law and the Luck of the Draw." 692.
} 
justification of punishment that views punishment as restoring a loss that has been bestowed upon the victim and the victim's family. Kadish argues that punishing a criminal does not restore anything at all, and the concept of restoration does not have any relation to the amount of punishment that a criminal should receive.

Since irrational laws that are in accordance with the harm doctrine are reflective of our intuitive moral judgments, Kadish insists that changing these laws would be risky, as it would essentially cast doubt upon humanity's ability to assess what is right or wrong. Kadish sums up our irrational system of punishment with a quote from Isaiah Berlin, which states that "out of the crooked timber of humanity no straight thing was ever made." ${ }^{26}$

So far, we have been introduced to Lewis' argument, which aims to rationalize our lesser punishment of attempts while maintaining that it may not be just, and Kadish's argument, which completely objects to our system of punishment due to the role that resultant luck plays in the causation of harm. In contrast, Michael S. Moore argues that it is justifiable to punish failed attempts less severely than completed crimes, because the criminal who succeeds at a crime is more morally blameworthy than one who fails. In this view, our current system is in accord with the principle of proportional punishment and the principle of desert.

In his essay on the role that harm plays in our assessment of moral blameworthiness, Michael S. Moore argues that successful attempts are more morally blameworthy than failed attempts. Before articulating this view, Moore aims to show that we have more control over the harm that we cause than Nagel's theory of resultant luck gives us credit for. Moore suggests that a resulting harm is not a matter of luck, and that we not only have control over our circumstances and the choices that we make, but also the harm that results from our choices. After deconstructing Nagel's control principle and the idea of resultant luck, Moore argues that harm plays a crucial role in moral blameworthiness because a criminal who inflicts harm will have a much stronger sense of moral guilt than a criminal who does not inflict a harm, and this harsher sense of guilt correctly translates to a more severe verdict during criminal sentencing.

Moore starts with his deconstruction of resultant luck, suggesting that

${ }^{26}$ Kadish, "The Criminal Law and the Luck of the Draw." 702. 
the term "luck" is not a proper representative of the true moral issue that is at stake regarding the debate on whether or not the causation of harm is relevant to moral blameworthiness. This is because our common use of the word luck is at odds with the way that Nagel uses the term when describing the causation of harm. For example, our society would describe a shooter as being lucky if his bullet hits his intended target, and Nagel would incorrectly deem this shooter as being unlucky due to his increased moral blameworthiness. Moore suggests that the "issue is better cast straightforwardly in terms of causation." 27 In other words, we should only be concerned with identifying the factors that are involved with the causation harm, such as the criminal's control over his actions and the subsequent result of his actions. In Moore's view, none of these factors involve anything we would commonly think of as luck.

After deeming luck as an irrelevant factor in the causation of harm, Moore addresses the common argument that we are only responsible for our actions, and that the resulting harm that occurs from these actions is beyond our control. Moore exemplifies that there is a serious problem with this notion by pointing out that the two premises of this argument are contradictory. The first premise to this argument uses a "compatibilist sense of control," which suggests that "we do not need to control every factor making a result possible; we only need a reasonable chance to have avoided the result." ${ }^{28}$ In other words, this premise suggests that we have control over the results of our actions whenever we control the chances of bringing them about. Under this premise, it would seem that a shooter should be held responsible for the death of his victim because he is in control of the risk he is presenting to his victim. The second premise, as Moore states, uses an "incompatibilist sense of control," which suggests that "we control some result only when we can make causally efficacious choices about every factor that could cause or prevent this result." ${ }^{29}$ In this sense of control, we are not even in control of our choices or intentions because we are not in control of every factor

\footnotetext{
${ }_{27}$ Moore, Michael S. "Causation and Moral Blameworthiness." Causation and Responsibility: An Essay in Law, Morals, and Metaphysics. By Michael S. Moore. N.p.: (Oup Oxford, 2015), 23.

${ }^{28}$ Moore, "Causation and Moral Blameworthiness." 25.

29 Ibid.
} 
that leads to them, such as our genetic make-up. The incompatibilist sense of control seems to correlate with Nagel's instances of constitutive, circumstantial, and antecedent luck, as it deems almost every aspect of who we are and how we act as being beyond our control. Moore immediately rules out this incompatibilist sense of control, as he states that we most certainly have control over our choices, intentions, and actions. Moore is concerned with whether or not it is possible to argue that in a compatibilist sense of control, we are in control of our intentions and actions, but not the results of our actions.

Moore points out that three philosophers by the names of Morse, Ferzan, and Alexander argue that even in the compatibilist sense of control, we are in control of our choices, intentions, and actions, but not their subsequent result. Their argument is that since "the only form of control a responsible actor needs is the general capacity to be guided by reason...compatibilists have good reason to draw the line at human action because only action can be guided by reason." ${ }^{30}$ Moore cannot wrap his head around this logic, and he exemplifies his counter-argument by introducing a situation where a man puts a gun to his victim's head, pulls the trigger, and kills him. Moore states that since the man has control over the choice to kill his victim, and this choice is guided by reason, he must also have control over the choice's intended effect of murdering his victim, because the act of shooting was guided by reason. For Moore, the suggestion that we only control what we directly cause is "too narrow a notion of control." 31

It is obvious that not every criminal act is one in which the criminal has complete control over every possible factor that could interfere with the outcome. As Moore points out, many philosophers conclude that there are different degrees of control that we can have over the "real-world effects" of our choices. ${ }^{32}$ In other words, we can't always predict the result of an intended action, no matter how likely it may seem to occur. Moore states that this notion of unpredictability is irrelevant because, as he has stated previously, our causation of harm is guided by our reasoning, thereby making us fully in control of the harm that we have caused.

\footnotetext{
${ }^{30}$ Moore, "Causation and Moral Blameworthiness." 27.

31 Moore, "Causation and Moral Blameworthiness." 28.

32 Moore, "Causation and Moral Blameworthiness." 29.
} 
Thus-far, Moore has simply deconstructed the common reformist notion that we are not in control of the harm that our actions have caused, and has stated that it is certainly not a matter of moral luck. However, Moore's rebuttal fails to state anything regarding why a criminal who causes a harm is more morally blameworthy than one who fails at an attempt to cause harm. Moore's argument regarding moral blameworthiness suggests that criminals who inflict harm upon their victims are more blameworthy because they are likely to feel a stronger sense of guilt than criminals who fail to cause harm. Moore states that when we fail to inflict a harm that we have either tried to cause or have unreasonably risked, our feeling of guilt is likely to be self-focused, and will most likely be combined with a sense of relief that a harm did not occur. When we cause a harm, we are likely to feel severe guilt that is not only self focused, but also focused on the suffering of the person that we have harmed. Moore concludes that when we cause harm, "the reason we feel so guilty... is we are so guilty." 33 Although Moore admits that some may condemn the fact that he is basing a moral argument around personal feelings, he says he "cannot see how to do moral philosophy if one puts aside the emotions." 34

Moore completely objects to the notion that we do not have control over the harm that we cause, and insists that the harm that we cause has a substantial effect on our moral blameworthiness. In sharp contrast, Joel Feinberg views harm as a matter of resultant luck, and his essay aims to provide a new way that our penal code could go about articulating criminal behavior so that the caused harm is completely left out.

In his essay "equal punishment for failed attempts," Feinberg takes what he classifies as a "reformist" position on how to treat successful and failed attempts of murder. The reformist position proposes a new way that our criminal justice system should treat crimes of murder and attempted murder, whereas a "retentionist" philosopher such as Moore would argue that our current system of punishment should remain. Essentially, the reformist position demands equal punishment for failed and successful attempts, insisting that moral blameworthiness is not influenced by the actual harm caused, as the harm caused is often a matter of resultant luck. This equal

\footnotetext{
${ }^{33}$ Moore, "Causation and Moral Blameworthiness." 30.

${ }^{34}$ Ibid.
} 
punishment would deem our legal system as being in accordance with the principle of proportional punishment, as this principle insists that the severity of punishment should be proportional to the moral blameworthiness of the criminal act. Feinberg states that punishing defendants based on their resultant luck brings arbitrariness into our legal system, and that "arbitrariness is to a legal system what corrosive rust is to machinery." ${ }^{35}$ Resultant luck is arbitrary because it is too general of a concept to accurately explain why we punish successful and failed attempts differently. By objecting to some popular retentionist arguments, Feinberg demonstrates his position that the equal punishment of both failed and successful attempts would rid our legal system of arbitrariness, and that this reformist position would correctly adhere to the principle of proportional punishment.

Feinberg begins his essay by proposing that we reform the wording of our penal code by eliminating the causal condition in the definition of completed crimes. For example, the crime of killing would instead be defined as "wrongful homicidal behavior," and the penal code would contain no clause that requires the "victim to actually die." ${ }^{36}$ Feinberg states that our penal code should be worded to insist that "any act of killing or attempted killing or the faulty or the faulty or blameworthy creating of an unreasonable risk of killing, whether or not the actor was aware of that risk, is an act of wrongful homicidal behavior." ${ }^{37}$ This definition is meant to leave out the causal condition of the actual harm and adhere strictly to the actus reus and mens rea elements involved in the act. Since blameworthiness is composed of many factors, the draftsmen of this hypothetical penal code could differentiate between first and second-degree wrongful homicidal behavior by assessing factors such as the criminal's intentions and the circumstantial conditions surrounding the crime. In this system, the causal condition of harm would have no affect on criminal sentencing, as the severity of the sentence would be assessed by factors that are relevant to deciding the criminal's actual blameworthiness.

After articulating his reformist proposal, Feinberg introduces and subsequently refutes a few common retentionist arguments. The first argument

\footnotetext{
${ }^{35}$ Feinberg, Joel. "Equal Punishment for Failed Attempts: Some Bad but Instructive Arguments Against It." Arizona Law Review 37.1 (1995): 118, accessed May, 2015, LexisNexis Academic [LexisNexis].

${ }^{36}$ Feinberg, "Equal Punishment for Failed Attempts." 119.

37 Ibid.
} 
comes from the liberalist perspective that acts should only be punished if they cause harm to other people, as it is not the government's business to regulate acts that they simply disapprove of. Feinberg states that this argument is obviously inapplicable to the crime of attempted murder, because the dangerousness of the criminal needs to be accounted for even if no harm is caused. The second argument that Feinberg refutes insists that a murderer is more blameworthy than a man who fails at attempting murder because he has caused more harm, therefore his punishment should be proportional to the amount of harm he has caused. Feinberg suggests that this argument is ill-advised because it views criminal law as being similar to tort law, which is a system of law that requires criminals to pay reparations that are proportional to the amount of damage they have inflicted on the victim. Feinberg insists that the purpose of criminal law is to punish defendants based on what they deserve, and to discourage society from performing dangerous conduct.

Lastly, Feinberg addresses "the argument from moral emotions," which suggests that a criminal offender who fails to inflict harm on another person is likely to feel far less guilty than an offender who causes harm, therefore making the successful offender more guilty in terms of criminal law. ${ }^{38}$ This argument, which is the basis of Moore's argument, suggests that a man who merely attempts murder but does not succeed would likely feel a sense of shame, as opposed to guilt. In response, Feinberg states that based on the way the English language uses the word guilt "even for acts and thoughts that are morally innocent in the judgment of others," the criminal who fails at a crime would surely feel a strong sense of guilt due to the fact that his behavior has violated the basic moral values that society has engrained in him. ${ }^{39}$ If the man who misses his shot due to mere luck does not feel a strong sense of guilt, than there is something wrong with his psychological wiring. Feinberg states that one is unlikely to feel shame in this case, because shame is something that one feels when we embarrass ourselves in our own eyes. Therefore, as Feinberg states, Moore's argument is irrational because a feeling of guilt is something that failed attempts can trigger just as easily as successful attempts.

Feinberg concludes his argument by re-presenting his reformist position. He states that our penal code should be worded in a way that articulates

\footnotetext{
${ }^{38}$ Feinberg, "Equal Punishment for Failed Attempts." 126.

39 Feinberg, "Equal Punishment for Failed Attempts." 128.
} 
whether or not a criminal has acted purposely, negligently, knowingly, or recklessly toward a harmful result. After the court establishes these factors, which determines whether or not the act is wrongful homicidal behavior, the sentence can be adjusted based on the criminal's moral blameworthiness. Blameworthiness is composed of factors such as the criminal's motivations, his intentions, and the circumstances involved with the crime. For example, if a criminal premeditatedly shoots a woman for rejecting him, the criminal may receive a harsher sentence than a criminal who impulsively shoots a man during an argument. While the reformist position demands equal punishment for failed and successful attempts, this position also insists that the severity of punishment should be based on the blameworthiness of the offender. By demanding equality, Feinberg is simply demanding that resultant harm of a crime should not play a role in the punishment of crime.

In response to Feinberg's essay, Barbara Herman develops an argument that suggests that there "might be good reasons to treat attempts separately." ${ }^{30}$ Although she doesn't define herself as a retentionist, Herman's argument offers a way of looking at criminal attempts that highlights factors other than moral blameworthiness, which is a perspective that makes the differential punishment of successful and failed attempts appear to be more rational than reformists such as Feinberg would like to believe.

Herman insists that in cases of failed criminal attempts, "we are sometimes unsure that the causal explanation for the failure is an external intervention. ${ }^{41}$ This statement alludes to Moore's theory that we have a certain degree of control over the results of our actions. Herman suggests that it is reasonable to believe that attempts may fail for many reasons, such as "a partial with-holding of will, an ambivalence of motive," and "a lack of whole-hearted dedication to the goal." ${ }^{2}$ While giving a vote of confidence to human-agency, Herman also insists that although what occurs beyond our moment of action is often beyond our control to some degree, "whether or not the world cooperates in our efforts... is not a matter of luck." ${ }^{43}$ Herman

\footnotetext{
${ }^{40}$ Herman, Barbara. "Feinberg on Luck and Failed Attempts." Arizona Law Review 37.1

(1995): 143, accessed May, 2015, LexisNexis Academic [LexisNexis].

${ }^{41}$ Herman, "Feinberg on Luck and Failed Attempts." 144.

42 Ibid.

43 Herman, "Feinberg on Luck and Failed Attempts." 147.
} 
is suggesting that the ability of our world to interfere with the success of our actions is something that every rational human being is aware of prior to committing a criminal act. As it is reasonable to believe that our actions will go as planned and not be interfered with, we are not lucky when our actions succeed. Herman insists that referring to the real world's interference with our actions as luck deems luck as morally irrelevant. In Herman's eyes, we are receptive of good or bad luck only when things occur that are not in accordance with we intend. Therefore, a criminal who tries to kills someone cannot state that he is either morally lucky or unlucky if he succeeds or fails, as the result of his action is simply a possible outcome of his action. While every criminal is equally likely to receive fortunate or unfortunate real-world effects during or after his act has been committed, Herman suggests that criminals cross a moral thresh-hold when they engage in dangerous behavior, and the causation of harm that this behavior brings about is imputable to them.

While Herman suggests that criminals should be held responsible for the harm that they cause, she does not dissect the notion that harm has an effect on moral blameworthiness. She is simply trying to show that it may be a good idea to place unsuccessful criminal attempts in a separate category because criminals are responsible for the harm that they cause, and harm is not a case of resultant luck. Herman also suggests that some criminal attempts are, by nature, different than the commonly used hypothetical scenario where a criminal shoots his intended victim. For example, in cases of rape, penetration must occur in order there to be any kind of rape. In shooting cases, a criminal can be said to have attempted murder whenever he pulls the trigger, whereas it is difficult to distinguish what would classify as an attempted rape. Herman states that in cases such as attempted rape, "we may want to preserve the distinctness of the attempt...to mark our conviction that we deeply care about the difference between rape and attempted rape..." ${ }^{44}$ Herman also insists that there is often a wide range of possible reasons for failure in cases of attempt, and it most likely wise that our legal system accounts for this range of possible failure. Some cases of attempt require multiple stages of action, and not all cases involve a temporal action such as shooting a gun.

While the common topic of discussion regarding attempts is often revolved

${ }^{44}$ Herman, "Feinberg on Luck and Failed Attempts." 146. 
around whether or not the causation of harm has any influence on moral blameworthiness, Herman's argument suggests that we may want to take a deeper look at the different factors involved with attempts. One factor that Herman states needs an explanation is the element of control that a criminal has over the harm that he intends to cause. Herman insists that when it comes to "contributions to the success" of our actions, we often have much greater control over certain things outside of our bodies than we have over ourselves. ${ }^{45}$ For example, when we are writing an essay, the computer we are using is generally more responsive to our goal of finishing the essay than we are, as our own laziness can interfere with our goal. This example is meant to demonstrate that in cases of attempted murder, the notion that the bullet hitting the victim is a matter of luck is irrational, as we have "a baseline sphere of effective agency" over our murder weapon. ${ }^{46}$ Furthermore, when criminal actions do not go as planned, one cannot say that luck plays a role in this because every criminal action is equally likely to be interfered with by a multitude of possible mishaps. In the case of a man who is carefully and legally driving his car down the street, if an inadvertent skydiver falls directly in the path of the man's car and is killed, the driver of the car could make a case that he has been a recipient of moral bad luck, as his behavior has not been dangerous.

Herman insists that since criminals who intend to commit crimes are responsible for the harm that they cause, a case can be made that it is justifiable to punish criminals who do not bear the responsibility of inflicting harm less severely. Herman states that when we engage in dangerous behavior, we cross a moral threshold and become eligible for punishment that is based on "what our actions have brought about." ${ }^{47}$ Whether or not criminals are actually more morally blameworthy when they inflict a harm is a philosophical question that Herman does not address.

It is apparent that the two main controversial issues that surround the concept of successful and failed attempts involve the amount of control we have over what our actions produce, and whether or not the causation of harm inflicts a greater amount of moral blameworthiness on us. David Lewis aims to justify our unequal punishment of successful and failed attempts while admitting that

\footnotetext{
45 Ibid.

46 Ibid.

${ }^{47}$ Herman, "Feinberg on Luck and Failed Attempts." 147.
} 
the causation of harm is a matter of resultant luck, and also that the causation of harm has no effect on a criminal's moral blameworthiness. Kadish suggest that our current system of punishment cannot be justified because of these reasons, and the unequal punishment of attempts does not facilitate the deterrent purposes of criminal law. Moore and Herman seem to suggest that we have far more control over how our actions turn out than Nagel's concept of resultant luck gives us credit for. They believe that there is a certain amount of human agency that plays a role in the causation of harm, and blaming everything that our actions produce on luck is not a rational line of thought. Moore seems to take the strongest retentionist position, as he believes that the causation of harm actually has a significant effect on moral blameworthiness. Feinberg rejects Moore's notion that we should decide moral blameworthiness based on the emotional feeling of guilt that a criminal may or may not feel after his crime. Furthermore, Feinberg is of the belief that we do not control what occurs beyond the moment of our actions, and our penal code should be worded to reflect the significant factors that contribute to moral blameworthiness, such as our motives and intentions.

I cannot fathom how one can come to the conclusion that we are not in control of the harm that we cause. While there may be factors that either facilitate the intended outcome of an action or interfere with the intended outcome, I believe that Moore has taken the correct stance by insisting that since our actions are guided by reason, the intended outcome of an action is a matter of our reasoning, which we have full control over. However, this is not why I believe that successful criminal attempts should be punished more severely than failed attempts. The deconstruction of the "lack of control" argument seems to only serve the purpose of falsifying the notion that successful criminals have been unfortunate in their resultant luck. However, one who takes this position could also argue that despite the fact that criminals are in full control of the harm that they cause, successful and failed criminal attempts should be punished equally because we should base our punishment on the morally heinous nature of the action itself. Feinberg has rejected the argument that criminals should be punished proportionally to the amount of harm that they cause, as this ideology should only apply only to tort law. Feinberg states that punishing a criminal does not restore anything, which I completely object to.

In my opinion, we should completely ignore the concepts of control, luck, and moral blameworthiness when it comes to deciding the proper punishment 
for a criminal. When we hand out a severe sentence to a criminal who has murdered his victim, it is common to see the victim's family crying and hugging in the courtroom, as if they are relieved that justice has finally been served. We can dissect the philosophical nature of attempts all we want, but we cannot ignore the fact that the causation of harm has far greater consequences for the emotional stability of many people. When a mother loses a son, part of her has essentially been broken. How can we say that these factors should have no influence on what the defendant is deserving of? A man who attempts murder and fails will in all likelihood serve a substantial amount of time in prison, and we should trust that this sentence will deter him from ever trying to commit murder again. I also think it is irrational to say that unequal punishment of successful and failed attempts does not aid in the general deterrence of crime. When one commits a crime, his intention is to be successful at it! If the threat of a punishment that stems from a successful attempt does not deter the criminal, than nothing will. Furthermore, I believe that when we punish a man less severely for failing at an intended crime, we are justified in doing so because he is deserving of the opportunity to repent for his actions, as his actions did not inflict any harm to another person. When a victim dies, the criminal should serve a harsher punishment because he should not be afforded the opportunity to repent for his crime, as his victim has not been afforded the opportunity to live another day.

To conclude, I believe that the people who have constructed our criminal justice system are perfectly aware that both successful and failed criminal attempts are equally heinous. However, I believe that the draftsmen could not ignore the impact that harm has on many people, and they must've felt that it was their duty to reflect the atrocity of harm and it's emotional repercussions in criminal sentencing. In response to reformists who believe that criminals who fail at attempts deserve equal punishment based on their equally dangerous and heinous actions, I would like to re-introduce a quote from Isaiah Berlin: "Out of the crooked timber of society, no straight thing was ever made." ${ }^{48}$

${ }^{48}$ Kadish, Sanford H. "The Criminal Law and the Luck of the Draw." The Journal of Criminal Law \& Criminology 84.4 (1994): 702, accessed May, 2015, Academic Search Premier [EBSCO]. 


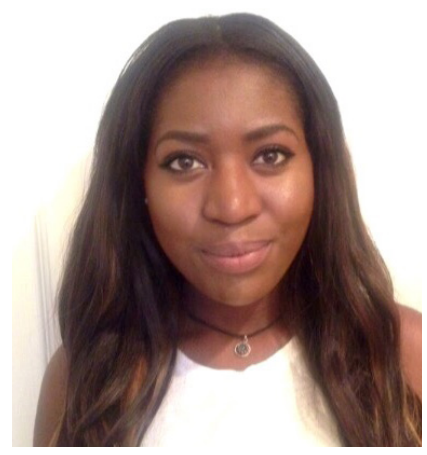

LUISA TEMBO is a third year Political Science major, with a concentration in Global Politics and a minor in Ethics, Public Policy, Science and Technology. She is involved in the ASI Executive Staff (Green Team) and Inter Housing Council (IHC). Her paper was inspired by the portrayal of human societies and the themes of interconnection in the documentary film Samsara (2011). 


\title{
NATIONAL DEVELOPMENT AND INDIGENOUS PEOPLES LAND RIGHTS
}

\section{Luisa Tembo}

\begin{abstract}
As the Western world gradually depletes their own lands, they migrate to developing nations and appropriate their resources. Sub-Saharan Africa is one of the most vulnerable regions in the world due to instability in the region. Globalization has perpetuated a cycle of exploitation that has made us increasingly interdependent on one another for survival. International organizations such as the IMF and the United Nations have attempted to aid indigenous peoples from corporations who take advantage of the overwhelming number of African governments that desperately desire to develop and advance their broken and corrupt nations. However, the structure of these institutions are incredibly duplicitous. In order to achieve sustainable development, there needs to be a fundamental change in the system. ${ }^{1}$ Nonetheless, intervention by these international organizations are vital for indigenous people's protection from corporate greed.
\end{abstract}

${ }^{1}$ John Perkins. Confessions of an Economic Hitman. (New York: Plume, 2005). http://resistir. info/livros/john_perkins_confessions_of_an_economic_hit_man.pdf 


\section{National Development and Indigenous Peoples Land Rights}

In Samsara (2011), there is a scene in a Sub-Saharan African village in Namibia that shows indigenous women from the Himba tribe, wearing very little clothing, lavish ornaments, and body paint made out of a mixture of red ochre and butterfat. They are surrounded by many smiling children who are also minimally clothed. In the background, you can see their huts made out of neatly piled branches and mud. To the average American living in an industrialized modern society, these living conditions may seem severely challenging. Although it may appear that they are living in extreme poverty, the Himba people are living a self-sustaining lifestyle. The following scene was a manmade landscape consisting of a double decker freeway system full of modern automobiles in North America. The drastic differences in lifestyles would lead one to believe that these scenes were taken centuries apart, however; these scenes were happening simultaneously in the 21st century. What historical premises lead to such drastic differences between these two regions? Specifically, how has their symbiotic relationship with nature been affected by their government's national development policies?

The Himba are an indigenous people that lead a semi-nomadic pastoral way of life. They are located in North-West Namibia, in the Kunene region, with a population size ranging from twenty-five to fifty thousand. ${ }^{2}$ Contrary to public misconception, they live in highly functioning, self-sustaining societies. By their standards, the Himba are a wealthy people, who enjoy a rich culture and a satisfying lifestyle. They live in an egalitarian society based on a bilineal family structure, shared ethnicity, and shared linguistics. Although they have no formal system of government or political organization, they have a traditional system of government based on chiefdoms, where head chiefs decide day-to-day matters. ${ }^{3}$ The Himba are considered to be some of the most successful and economically independent subsistent farmers in Africa. Their strategies for food security have proven successful even in times of severe drought. This is important because Namibia has an extremely dry climate that often leads to severe water shortages in

\footnotetext{
${ }^{2}$ Henning Melber. "Re-examining Liberation in Namibia: Political Cultures since Independence.” (Uppsala: Nordic Africa Institute, 2003), 48.

${ }^{3}$ Sidney L. Harring. "God Gave us this Land: The OvaHimba, the proposed Epupa Dam, the independent Namibian state, and law and development in Africa." Georgetown International Environmental Law Review, 14(1) (2001): 35-106, accessed December 2, 2015, http:// search.proquest.com/docview/225506935?accountid=10362.
} 
many parts of the country for often long periods of time. ${ }^{4}$ Pastoralism is common in Himba society as the Himba "economy" is based on cattle trade, with herds averaging 100 per family and reaching at least 500 for some wealthy families. Owning many livestock such as cattle, sheep, and goats, is a sign of affluence. ${ }^{5}$

To understand the complexity of their recent environmental problems, an examination of Namibia's history is necessary. Namibia, like many other SubSaharan African countries, has a long history of colonial rule. It was under German colonial rule from 1883 to 1915. After Germany suffered a loss in WWI, Namibia was under the control of the League of Nations, then the United Nations. Under the mandate, the territory, called South West Africa at the time, was administered by South Africa, who was under British and Dutch rule. $^{6}$ The colonial powers of South Africa institutionalized racism through racially discriminatory apartheid policies that affected the social, political, and economic lives of the black minorities. Governmental attempts at reforming civil society were motivated largely by political and ideological concerns. For example, the creation of an all-white Advisory Council in 1921 to advise the South African-appointed Administrator, the introduction of English and Dutch as official languages, and Roman-Dutch Law as the common law in Namibia, land policy, education policy, as well as the active encouragement of white settlement, were all concentrated efforts in reconfiguring the public sphere in Namibia so as to contain the movement of the majority black population. ${ }^{7}$

The colonizers main goal was to utilize the resources of the colonies for profit. Private ownership of land was highly restricted and incredibly rare; the locals

\footnotetext{
${ }^{4}$ Ibrahima Thomas, and Moses Chakanga, "Role of Planted Forests and Trees Outside Forests in Sustainable Forest Management" FAO Corporate Document Repository, 2001, May 21. http://www.fao.org/docrep/009/j5838e/J5838E10.htm.

${ }^{5}$ Sidney L. Harring. "God Gave us this Land: The OvaHimba, the proposed Epupa Dam, the independent Namibian state, and law and development in Africa." Georgetown International Environmental Law Review, 14(1) (2001): 35-106, accessed December 2, 2015, http:// search.proquest.com/docview/225506935?accountid=10362.

${ }^{6}$ James Anaya. "Report of the Special Rapporteur on the Rights of Indigenous Peoples: The Situation of Indigenous Peoples in Namibia." United Nations Human Rights Council, June 25, 2013, http://www.iwgia.org/iwgia_files_news_files/0921_2013-report-namibia-a-hrc24-41-add1-en.pdf.

7 Ibrahima Thomas, and Moses Chakanga, "Role of Planted Forests and Trees Outside Forests in Sustainable Forest Management" FAO Corporate Document Repository, 2001, May 21. http://www.fao.org/docrep/009/j5838e/J5838E10.htm.
} 
were disposed of their lands and many indigenous people lost their lands as well. The Himba's herds were an economic threat to South African interests. In response the colonial administrators placed restrictions on livestock and cut off opportunities for trade and wage labor. They controlled the border with Angola by forbidding Angolan traders in the territory, and by attempting to stop the Himba and their cattle from freely crossing the border. ${ }^{8}$ The impact of closing these borders was devastating to the Himba because most of their traditional trade routes were no longer available. South Africa's intent was to destroy the Himba pastoral economy in order to force them into signing migrant labor contracts and working in South African mines. ${ }^{9}$ The Portuguese, who had colonized Angola, also restricted the economic activists of the Himba on the Angolan side of the Kunene. With these few exceptions, the Himba lived in relative isolation apart from colonial rule in comparison to other Namibians. As a result, the Himba have been able to preserve their way of life because the Himba deliberately stay distinct from Namibian society. ${ }^{10}$

Desperate for liberation, Namibians petitioned the United Nations against South African rule and a concentrated effort towards independence began. In 1988, South Africa finally agreed to end its administration, and on March 13, 1990, Namibia finally gained its independence. ${ }^{11}$ They established a multiparty constitutional democracy, and became the first African country to incorporate protection of the environment into its constitution. ${ }^{12}$ Today, it still remains one of the few countries in the world who has put such an emphasis on protection of natural resources and habitat conservation in their constitution. The Namibian government was successful in repealing many of their previous colonizers oppressive laws. However, the Namibian constitution states that all

\footnotetext{
${ }^{8}$ Ibid.

${ }^{9}$ Sidney L. Harring. "God Gave us this Land: The OvaHimba, the proposed Epupa Dam, the independent Namibian state, and law and development in Africa." Georgetown International Environmental Law Review, 14(1) (2001): 26, accessed December 2, 2015, http:// search.proquest.com/docview/225506935?accountid=10362.

${ }^{10}$ James Anaya. "Report of the Special Rapporteur on the Rights of Indigenous Peoples: The Situation of Indigenous Peoples in Namibia." United Nations Human Rights Council, June 25, 2013, http://www.iwgia.org/iwgia_files_news_files/0921_2013-report-namibia-a-hrc24-41-add1-en.pdf.

${ }^{11}$ Ibid.

12 “Namibia," World Wildlife Fund. n.d. http://www.worldwildlife.org/places/namibia.
} 
land, water, and natural resources of Namibia belong to the state. ${ }^{13}$ This policy is extremely reflective of their European colonizers way of thought, and further perpetuates inequity in society. There are also no specific rights to indigenous peoples as all traditional communities are considered indigenous to Namibia under its constitution, which completely undermines the necessary regard needed of indigenous minorities as well as their special needs. ${ }^{14}$

Nonetheless, the government does provide assistance to disadvantaged groups in many ways. One of the most substantial programs it passed was its legislation on communal conservancies. Communal conservancies are a legally registered area with clearly defined borders and a constituted management body run by the community for the development of residents and the sustainable use of wildlife and tourism. They are a key development strategy for rural Namibia as they cover $17 \%$ of the country, and approximately one in four rural Namibians now belongs to a registered conservancy.7 The Himba, as well as other indigenous groups in the area are recognized as particularly marginalized by the Namibian government and there are laws and policies particularly devoted to their needs. ${ }^{15}$ Additionally, tourism is a growing industry, contributing to $20 \%$ of the country's GNP, and is used as a lever for economic growth within African conservancies. ${ }^{16}$ One of the country's main concerns is how to sustain the environment while developing ecotourism. However, because the Himba live within communal areas, the tourist industries encourage visiting the indigenous tribes, and sometimes paint an inaccurate depiction of these tribes by using phrases such as "historically disadvantaged people" as a selling point. ${ }^{17}$

The dispute of the Himba people's land and natural resource rights was

\footnotetext{
${ }^{13}$ Henning Melber. "Re-examining Liberation in Namibia: Political Cultures since Independence.” (Uppsala: Nordic Africa Institute, 2003), 48.

${ }^{14}$ Ibid.

${ }^{15}$ James Anaya. "Report of the Special Rapporteur on the Rights of Indigenous Peoples: The Situation of Indigenous Peoples in Namibia." United Nations Human Rights Council, June 25, 2013, http://www.iwgia.org/iwgia_files_news_files/0921_2013-report-namibia-a-hrc24-41-add1-en.pdf.

${ }^{16}$ Anene Ejikeme, Culture and Customs of Namibia. (Westport: Greenwood Publishing Group, 2011), 23.

17 A.P. Davis, "Consequences of 'conservation': A Critical look at Namibian Communal Conservancies," 2011, https://dlc.dlib.indiana.edu/dlc/bitstream/handle/10535/7179/\%20Namibia.pdf?sequence $=1$.
} 
discussed because of the government's desire, as a newly independent country, to develop. In the mid 1990s, the Namibian government wanted to invest in development in order to become a global player capable of writing their own course. The Himba and the government have competing interests when it comes to the use of the Kunene River. The Kunene River is one of three permanently flowing rivers that supports a unique ecosystem in the North-West border of Angola and Namibia. ${ }^{18}$ It is the largest body of water by the Himba people, who get their livelihood from the river. In order to help supply energy to its people, the Angolan and Namibian government proposed a hydropower scheme called the Epupa Dam project. Namibia had an increasing need for power and considered the river as a gift from nature that needed to be utilized to build a hydro-electric power dam. There was a lot of controversy as to whom this dam would benefit most because most of the energy was being distributed to the urban areas, which was less densely populated than the rural areas. ${ }^{19}$ NamPower, Namibia's main energy supplier advocated for the dam as it was importing up around $50 \%$ of its power from South Africa, and wanted to diminish its dependency on foreign powers for energy. ${ }^{20}$ The feasibility study was supported and funded by Norway and Sweden. The project would have two sites: at the Epupa river and the Baynes river. The Namibian government insisted that the dam be built at the Epupa Falls site on the Kunene River instead of the Baynes site because it has greater use value than the Baynes site, regardless of the fact that research showed that the environmental and social costs on the Himba would be much greater. ${ }^{21}$

\footnotetext{
${ }^{18}$ Sidney L. Harring. "God Gave us this Land: The OvaHimba, the proposed Epupa Dam, the independent Namibian state, and law and development in Africa." Georgetown International Environmental Law Review, 14(1) (2001): 35-106, accessed December 2, 2015, http:// search.proquest.com/docview/225506935?accountid=10362.

${ }^{19}$ Andrew Corbett. "A Case Study on the Proposed Epupa Hydropower Dam in Namibia." Prepared for Thematic Review I.2: Dams, indigenous people and vulnerable ethnic minorities, December 1999, http://citeseerx.ist.psu.edu/viewdoc/download?doi=10.1.1.196.5858\&rep=rep1\&type=pdf.

${ }^{20}$ Ibid.

${ }^{21}$ Sidney L. Harring. "God Gave us this Land: The OvaHimba, the proposed Epupa Dam, the independent Namibian state, and law and development in Africa." Georgetown International Environmental Law Review, 14(1) (2001): 26, accessed December 2, 2015, http:// search.proquest.com/docview/225506935?accountid=10362.
} 
The Eupa site is significant because it is utilized by the Himba for survival. ${ }^{22}$ The Himba opposed the proposed dam as the consequences would have been severe. First, there would be a flooding of the heart of their lands with a reservoir, which would result in a loss of biodiversity. Second, there would be a disruption of their lives and culture. Although the Himba are nomadic, some families are well established in some areas. The Epupa site would have flooded 110 permanent dwellings of the Himba, resulting in the displacement of many people. It would also affect the drought strategies of many Himba people, as it is a crucial source of grazing and browsing in dry seasons and in times of drought. ${ }^{23}$ One of the main reasons for opposition towards the dam would be that of culturally-important ancestral graves. The graveyards have a diverse array of functions and significance in Himba society. The Himba believe that their culture will be at risk as the graveyard is far more than just the physical remains of a deceased person; it is the focal point for defining identity, social relationships, and relationships with the land, as well as being the center for important religious virtues. ${ }^{24}$ The graves are also a way of determining land "tenure" which is based on continuity of settlement, and allows those who can demonstrate the longest connection with the land the strongest say over land-related matters such as rights of access and control over resources. ${ }^{10}$ Because of their inferior position to the state, the Himba's traditional leaders got lawyers, and won the case against the state. Ultimately, the situation caused mistrust between the government and the Himba for misleading them, ignoring them, and for trespassing on their lands without acknowledging their rights. ${ }^{25}$

A prolonged period of colonization and slavery have had a debilitating effect on Sub-Saharan Africa. Throughout the continent, the European colonizers changed ethnic relations by drawing political boundaries, patterns of social organization, and exploiting their natural resources. It has resulted in a huge

\footnotetext{
${ }^{22}$ Andrew Corbett. "A Case Study on the Proposed Epupa Hydropower Dam in Namibia."

Prepared for Thematic Review I.2: Dams, indigenous people and vulnerable ethnic minorities,

December 1999,

${ }^{23} \mathrm{Ibid}$.

${ }^{24}$ Ibid.

${ }^{25}$ Sidney L. Harring. "God Gave us this Land: The OvaHimba, the proposed Epupa Dam, the independent Namibian state, and law and development in Africa." Georgetown International Environmental Law Review, 14(1) (2001): 35-106, accessed December 2, 2015, http:// search.proquest.com/docview/225506935?accountid=10362.
} 
development gap between colonial masters and their former colonies. The colonizers saw no need to invest in development in their colonies unless it served their needs. Because the economy was based on export agriculture, all good arable lands were controlled by wealthy colonial landowners. ${ }^{26}$ The decolonization process was extremely violent but successful because the states gained autonomy. However, gaining independence didn't level the playing field, as they were highly disadvantaged and left in a state of disorder. Governments faced economic, social, and political problems due to limited experience, evidently resulting in corrupt governance. The Epupa Dam proposal is one of many examples of the clash between traditionalism and modernism in the developing world. Furthermore, it demonstrates how hydropolitics and resource management has become a central issue in the developing world. Due to such disparities in economic and political development, foreign intervention is almost always necessary to help accelerate development because the developing countries lack the means to obtain the ends. Unfortunately, the result is an extension of the colonial development relationship, which tends to result in the pushing of a Western agenda on people not yet fully integrated into the global capitalistic system. ${ }^{27}$

Although it's a combination of a prolonged period of colonization, physical geography, corrupt governance, and poor policies, ever-evolving international structures are perpetuating inequity in the global economy. ${ }^{28} \mathrm{~A}$ leading problem in less developed countries (LDCs) is that they are resource rich countries but they are growing much slower than resource scarce countries due to the exploitation of those resources by more developed countries (MDCs) who have a large appetite for resources. They are also extremely vulnerable because we have become such a global economy, making them susceptible to world market prices. Therefore, they must invest in development within their countries, however; they lack the financial ability to do so. In today's world, development is associated with Western, capitalistic style economies.

\footnotetext{
${ }^{26}$ Lester Rowntree et al., Diversity amid globalization: World regions, environment, development (6th Edition). (New York: Pearson, 2014).

${ }^{27}$ A.P. Davis, "Consequences of 'conservation': A Critical look at Namibian Communal Conservancies,” 2011, https://dlc.dlib.indiana.edu/dlc/bitstream/handle/10535/7179/\%20Namibia.pdf?sequence $=1$.

${ }^{28}$ Donald M. Snow. Cases in International Relations (6th Edition). (Upper Saddle River: Prentice Hall, 2014), 222.
} 
International organizations such as the World Bank and the International Monetary Fund (IMF) both assist developing countries in times of economic instability and financial crises by granting loans that are tied to a set of lending conditions. ${ }^{29}$ Although they serve a great purpose, these organizations are far from innocuous as they serve the interests of the core countries in the world. Although they make sizable loans to developing countries as to support sustained economic growth, their Structural Adjustment Programmes have been heavily criticized and received great opposition by the developing world. ${ }^{30}$ These structural adjustment policies have a Western agenda that promotes liberal values in an attempt to democratize these nations. Nicoll (1997) states that "The World Bank, which is not involved in funding the Epupa project, has a long and dismal history of financing large scale development projects in the Third World that are modeled on western conceptions of development, run up huge debt, and do great damage to indigenous peoples and the environment." The large funding of these international organizations by wealthy states also causes a conflict of interest as they can highly influence policies. ${ }^{13}$ Such was the case in South America, which lead to the Bolivarian Revolution in the early 2000's in Venezuela lead by Hugo Chavez, that also influenced leaders in Argentina and Bolivia to rebel against neo-imperialism. It was a leftist socialist movement that was against neocolonialism, a new world order birthed from globalization that promotes global capitalism. ${ }^{31} \mathrm{We}$ also saw a similar rise in land reform from the Zapatistas in Mexico who rose in 1994 in response to the North American Free Trade Agreement (NAFTA), which was detrimental to small farmers in Mexico as it increased corporate influence in agriculture and trade. The Zapatistas were alter-globalization and no longer wanted to be subservient to the Western powers. ${ }^{32}$

In modern times, Indigenous peoples are granted various rights under international law, including a right to their traditional lands, to maintain their cultures, and some measure of local sovereignty to protect those lands

\footnotetext{
${ }^{29}$ Robert Paarlberg. Food politics: What Everyone Needs to Know (2nd Edition). (New York: Oxford University Press, 2013), 209.

${ }^{30}$ Ibid.

${ }^{31}$ Oliver Stone. South of the border. (June 25, 2010) https://www.youtube.com/watch?v=tvjIwVjJsXc.

${ }^{32}$ Ibid.
} 
and cultures. ${ }^{33}$ There have also been new international laws concerned with the displacements of indigenous peoples displaced by the construction of large dams. They state that no government should do harm to poor peoples in order to advance particular schemes of national development. World Bank standards now requires both careful and systematic study of the impact of large dams on local populations, as well as additional standards requiring that forced removals not occur unless the displaced peoples can be relocated without loss of their culture in a position where they are at least as well off economically as they were before relocation..$^{34}$ In 1993, the United Nations Commission on Human Rights adopted a resolution condemning forced evictions as "a gross violation of human rights."35

Globalization is making humanity increasingly interdependent on one another socially, politically, and economically. Although globalization affects everyone, there are vast differences in societies because countries have developed at different rates. The economic disparities between the LDCs and MDCs are emphasized in this new world order, and it is quite evident that not everyone reaps the same benefits from globalization. ${ }^{12}$ One of the defining factors that separates the MDCs from the LDCs are the amount of investments that the government makes in human development. This includes investments in land reform, and often times, indigenous societies are underrepresented and marginalized because of Western ideology of development, and therefore, "economies based on indigenous technologies have been viewed as backward and unproductive because of the distorted concept of patriarchal productivity." ${ }^{36}$

\footnotetext{
${ }^{33}$ Nicoll Ruaridh. "Himba drowning in their desert Eden Namibia's hydro power scheme is endangering an ancient nomadic tribe," The Observer (1997) http://ezproxy.lib.calpoly.edu/ login?url=http://search.proquest.com/docview/250406608?accountid=10362.

${ }^{34}$ Ibid.

${ }^{35}$ Ibid.

${ }^{36}$ A.P. Davis, "Consequences of 'conservation': A Critical look at Namibian Communal Conservancies,” 2011, https://dlc.dlib.indiana.edu/dlc/bitstream/handle/10535/7179/\%20Namibia.pdf?sequence $=1$.
} 


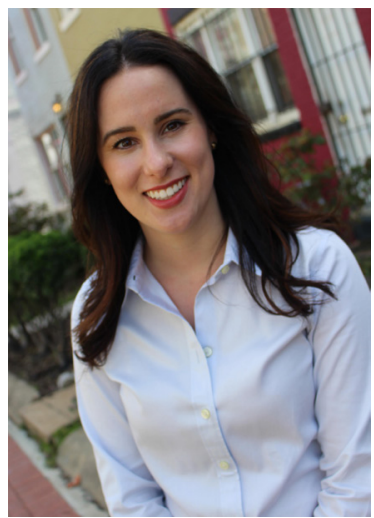

LINDSEY CONSTANTINO is a Program Associate for the U.S. Department of Transportation's Pipeline and Hazardous Material Safety Administration. She graduated from Cal Poly with a Political Science degree in 2013. 


\section{ALUMNI SPOTLIGHT}

\section{Lindsey Constantino}

Lindsey Constantino did not waste any time while she attended Cal Poly. From being a member of Kappa Alpha Theta to multiple internships, she took full advantage of the opportunities available. Originally, Lindsey did not have any aspirations in the field of politics. She came to Cal Poly as a History major, but after witnessing the 2008 presidential election and the beginning of President Obama's first term in office, Lindsey found her interests shifting and decided to major in political science. This passion would lead her to take on various jobs, each providing her with a unique experience.

The class structure at Cal Poly greatly benefited Lindsey. Discussions made her more comfortable with public speaking, which has been a great aid in conference calls and meetings with officials and coworkers. She could make sure that her opinions were heard without any embarrassment. Also, critical thinking skills allowed her to analyze large amounts of information with ease.

One of her best experiences at Cal Poly was with the school's Model United Nations Team (MUN). "This class takes Cal Poly's motto of learn by doing to heart, as you are able to practice what you learned in the classroom in New York City," she said. Lindsey participated in MUN multiple times. Her east coast adventures familiarized Lindsey with the area, and ended any fears she had about moving to the east coast after graduation. These were not her only 
trips outside of California. Lindsey was also a White House Intern in the fall of 2012. This internship has continuously had a positive impact in her career searches, and she still participates in the White House Internship through an Alumni Professional Development Committee. The White House has even invited her to return recently as a part of an "Internship Homecoming." Lindsey also spent time in Italy as part of the CSU's study abroad program.

Lindsey's work experiences have been equally as varied as her experiences at Cal Poly. Only 3 days after graduation she started working as an intern for Net Optics, a Silicon Valley company. Here she was able to grow her professional network by forging close relationships with staff, as well as acquire knowledge outside the usual confines of politics. From Net Optics, she moved on to become a Program Coordinator for the Institute of International Education (IIE). Of the multiple programs she worked on at IIE, one of her proudest was working with the Brazilian government to provide 100,000 Brazilian university students an opportunity to study in the U.S. These work experiences expanded Lindsey's skills in one particular way or another and they are all responsible for helping her acquire her current job with the U.S. government.

Lindsey now works under contract for the U.S. Department of Transportation's Pipeline and Hazardous Material Safety Administration (PHMSA) as a Program Associate. She is responsible for communicating with stakeholders and writing briefs for the Office of Hazardous Material Safety, and also works on federal projects. Lindsey is currently helping execute Fixing America's Surface Transportation (FAST) Act. The FAST Act's purpose is to advance important transportation projects, and specific mandates that Lindsey oversees involve the safe transportation of energy products, such as crude oil. Lindsey has always had a passion for public service, but she is still trying to narrow down her interests. Within the next few years she plans to further her education by attending graduate school, and from there the possibilities for such a distinguished alum are endless. 


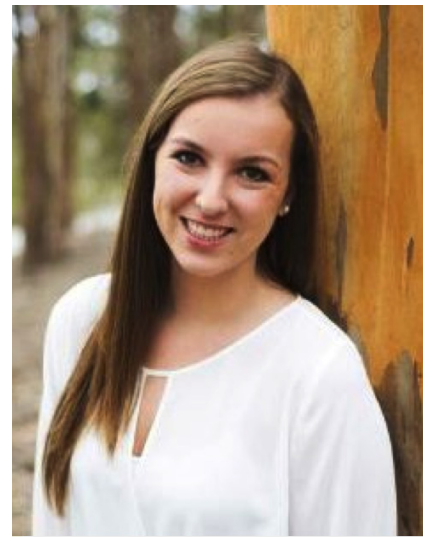

KRISTEN HENRY is a fourth year Business Administration major with a minor in Political Science. She began writing this paper while taking the course Critical Issues in American Politics. The more she learned about the Common Core standards, the more interested she became in assessing its true value. After she graduates, Kristen will be moving to Austin, Texas, to be a consultant for a software company. 


\section{AN EXAMINATION OF THE DEBATE SURROUNDING CORE CURRICULUM STATE STANDARDS IN AMERICAN EDUCATION REFORM}

Kristen Henry

\section{Core Curriculum State Standards in American Education Reform}

The creation and implementation of the Common Core State Standards (CCSS) has been a heated topic of debate in American politics, garnering attention from teachers, school administrators, and parents across the country. Many states have adopted these guidelines, which are a set of learning objectives for students at each grade level in Mathematics and English-language arts. ${ }^{1}$ Since its original implementation, however, support for CCSS has been wavering, with criticism coming from both Republicans and Democrats. ${ }^{2}$ Many supporters of Common Core State Standards argue that implementation will create a uniform level of comparison between states and ensure that

\footnotetext{
${ }^{1}$ Williams, Cheryl S. "Just the Facts: Common Core State Standards." Educational Horizons 90.4 (2012): 8-9.

${ }^{2}$ Guillory, John. "The Common Core And The Evasion Of Curriculum." PMLA: Publications Of The Modern Language Association Of America 30.3 (2015): 666-672.
} 
the nation adequately prepares students for life beyond high school, while critics address the program's associated costs and inability to target the real issues behind education inequality. Whether or not this program is the best path for America's education system moving forward is still up for debate.

The Common Core Standards themselves were designed by the National Governors Association for Best Practices (NGA) and Council of Chief State School Officers (CCSSO), and are aimed to "prepare students for college, career, and beyond." ${ }^{3}$ In addition to the NGA and the CCSSO, private groups were involved in the development as well. ${ }^{4}$ The most notable contribution came from the Bill and Melinda Gates Foundation, a large and powerful philanthropy group. ${ }^{5}$ Additional support and funding came from many educational interests including ACT, Microsoft, The College Board, McGrawHill Education, and Pearson Education. ${ }^{6}$ The standards were developed with contributions from these private groups whose relevant interests may impede on their ability to make impartial policy choices. In 2009 the Department of Education announced a fund called the Race to the Top, which encouraged "states to compete for $\$ 4.35$ billion by earning points based on education reform plans," which they would have the chance to adopt. ${ }^{7}$ The program made it clear that to be competitive, a state must include "internationally benchmarked standards and assessments that prepare students for success in the workforce and college," ${ }^{8}$ which was another way of saying they must adopt CCSS and its respective assessments. ${ }^{9}$ In 2010, forty-six states applied, twelve of which received federal funding. ${ }^{10}$ As of Fall 2014, four states had

\footnotetext{
${ }^{3}$ Burks, Brooke. "Adapting To Change: Teacher Perceptions Of Implementing The Common Core State Standards." Education 136.2 (2015): 253-258.

${ }^{4}$ Crowder, Zan. "From The Editorial Board: The Politicization Of The Common Core." High School Journal 98.1 (2014): 1-4.

5 Ibid.

${ }^{6}$ Ibid.

7 Frye, Kristopher. "Can The Common Core Counter Educational Inequity? International Legal Lessons On Closing The Achievement Gap." Indiana International \& Comparative Law Review 25.3 (2015): 493-540.

8 Toscano, Michael. “The Common Core: Far From Home.” Academic Questions 26.4 (2013): 411-428.

9 Op. Cit., fn. 7

${ }^{10}$ Op. Cit., fn. 8
} 
withdrawn from their commitment due in part to the high costs associated. ${ }^{11}$ As the program develops, states are continuing conversations about its effectiveness for educational reform.

Supporters of the Common Core State Standards maintain that implementation will create a consistent level of comparison between states and effectively prepare students for an international job market. A uniform set of standards "would address the problem of curriculum variation in the United States." 12 This consistency between state education systems would "promote educational equity" and allow for accurate comparative assessments between states. ${ }^{13}$ The wide variability that exists within a less centralized system of state-generated guidelines makes such a comparison nearly impossible. A common core system would also be especially beneficial to families who move between states by reducing repetition or gaps in their K-12 education. Another area that is often cited in support of CCSS is one of the program's main objectives: to "prepare students to compete in the ever-changing job market and the global economy." 14 According to a 2013 study conducted by the US Department of Education, 20\% of college freshmen reported that they had been enrolled in a remedial course during their first year in higher education. ${ }^{15}$ Burks argues that CCSS will reduce the need for these course offerings at colleges and universities, and better prepare students for college-level coursework. ${ }^{16}$ Supporters of CCSS reason that these standards will raise levels of expectation and transparency throughout American education, and will also provide students with "a certain set of educational skills one must have to be successful in academia or business." ${ }^{17}$ This central skill set is crucially important for students everywhere, and the uniform tests would allow policymakers to make accurate comparisons between states.

Critics of CCSS argue that the federal government is reaching too far with the program, that it does not adequately address the real issues within

\footnotetext{
${ }^{11}$ Op. Cit., fn. 4

${ }^{12}$ Op. Cit., fn. 3

13 Op. Cit., fn. 7

${ }^{14}$ Op. Cit., fn. 3

15 Op. Cit., fn. 3

${ }^{16}$ Op. Cit., fn. 3

${ }^{17}$ Op. Cit., fn. 7
} 
education, and that the associated costs are too high. Toscano writes that the biggest flaw of state standards is due to their disordered relation to social spheres and the "full reordering of American education away from families and local communities." ${ }^{18}$ He argues that the actions of the federal government were unilateral, merely concealed as being in the interest of the states, and primarily focuses on the overpowering involvement of the Bill and Melinda Gates Foundation. ${ }^{19}$ He argues that their "aggressive spending power" and incentive structure made it difficult for states to turn down the chance to seek funding. ${ }^{20}$ Although the decision to adopt CCSS was noncompulsory, states with struggling education budgets would be hard-pressed to turn down such an opportunity. Whether or not the path to common core was the most democratic, there are still criticisms regarding other aspects of the program, particularly how CCSS addresses the effect of poverty.

Supporters claim that CCSS is necessary to compete internationally, and they often cite America's comparatively poor performance on standardized assessments. Upon closer inspection, research indicates that "analyses of our international test scores ... are nowhere nearly as bad as critics claim and that they have not declined." ${ }^{21}$ Scholars like Stephen Krashen of the University of Southern California have found through "longitudinal international studies...that low test scores are largely clustered in the poorest school districts, while middle-class American students in well-funded schools score at the top of the world on international tests." 22 This is a crucial discrepancy to acknowledge, especially since poverty levels play a big part in education both through both student distribution and state funding. A study conducted at the College of William \& Mary found that "economic segregation in public schools is higher than expected [when compared to] the distribution of poverty across neighborhoods." 23 This is especially concerning because the

\footnotetext{
${ }^{18}$ Op. Cit., fn. 8

19 Ibid.

${ }^{20}$ Ibid.

${ }^{21}$ Krashen, Stephen. “The Common Core.” Knowledge Quest, 2014: 36-45.

${ }^{22}$ Wexler, Alice. "Reaching Higher? The Impact Of The Common Core State Standards

On The Visual Arts, Poverty, And Disabilities." Arts Education Policy Review 115.2 (2014): 52-61.

23 Saporito, and Sohoni. "Mapping Educational Inequality." Social Forces 85, no. 3 (2007).
} 
same study indicated a "strong correlation between school-level poverty rates and the academic achievement of individual students. ${ }^{24}$ Implementing a common set of guidelines across the nation overlooks the effect of poverty levels on educational achievement, primarily when they exist within the states themselves. The overbearing focus on CCSS over more serious issues detracts resources from significant programs like food security, healthcare, and access to books, that impact school performance. ${ }^{25}$

The additional costs associated with CCSS are another area of concern. The new assessments require computer hardware and software, and a new set of learning objectives requires new textbooks. ${ }^{26}$ This is especially concerning for students in high poverty schools since "the size of the gaps in achievement among schools and districts suggests that the additional costs will be high." ${ }^{27}$ Many districts struggle with budgets and providing attractive teaching salaries, resulting in less experienced teachers who serve high proportions of minority students and students living in poverty. ${ }^{28}$ The addition of more costs and required resources would put an even larger strain on communities with fewer instructional resources to begin with, and may perpetuate the educational gap the program aims to remedy.

After examining the Common Core Standards laid out by the federal government, it is hard to disagree with the objectives. Preparing students for college and the workforce, staying competitive among other nations, and creating an education system that can be benchmarked are all respectable goals. The biggest issue within CCSS, however, is not the stated guidelines, but the oversimplification of underlying problems that the standards claim to improve. Toscano states that the "Common Core... is a product of major misdiagnosis of what ails American schooling" 29 and that "[e]ducational success... is dependent upon the child's ability to participate in healthy families and

24 Ibid.

25 Op. Cit., fn. 21

26 Ibid.

${ }^{27}$ McPartland, James M, and Barbara Schneider. "Opportunities To Learn And Student Diversity: Prospects And Pitfalls Of A Common Core Curriculum.” 1996: 66-81.

${ }^{28}$ Hammond, Adamson, and Darling Hammond. "Funding disparities and the inequitable distribution of teachers: Evaluating sources and solutions." Education Policy Analysis Archives 20 (2012).

29 Op. Cit., fn. 8 
communities." ${ }^{30}$ This distinction puts children in poverty, and by extension a high population of minority children back at the starting line, or possibly worse. CCSS has a heavy emphasis on assessment to track the development of the program, and Wexler points to research that says "the social effects of poverty... are factors that contribute to learning....and, inevitably, low performance on standardized tests." ${ }^{31}$ This speaks to the greater problem that CCSS fails to address, which "is the child outside of school." ${ }^{22}$ Children with unstable living situations, estranged families, or who do not receive their proper meals are not able to concentrate at the level necessary to succeed in the classroom. One other overarching issue that makes the argument for CCSS even less compelling is the process by which the standards came about. Criticism has arisen from many experts, including James Milgram, professor emeritus of mathematics at Stanford. Milgram was a member of the Common Core Validation Committee, and refused to sign off on the standards. He noted the high risks associated with implementation, and claimed "[with the CCSS] we are dealing with an experiment on a national scale." ${ }^{33}$ Others have called for the public to "demand that experiments and descriptive studies of groups of students be carried out so that the standards and measure can be evaluated." ${ }^{34}$ This argument is especially critical since one of the overarching goals of CCSS is to increase educational equity. ${ }^{35}$

At this point, more research is necessary to evaluate whether or not the Common Core State Standards will have the positive effect they are intended to. The goals themselves are respectable, however the program must take on a more holistic view of underlying issues such as poverty and funding discrepancies. Policymakers and researchers should utilize their resources to conduct testing on a smaller scale before implementing the program nationwide. It is not clear whether or not CCSS is the best solution for America, but supporters and critics can both agree that effective and lasting educational reform is long overdue.

\footnotetext{
30 Ibid.

31 Op. Cit., fn. 22

32 Op. Cit., fn. 22

33 Op. Cit., fn. 8

34 Op. Cit., fn. 21

35 Op. Cit., fn. 1
} 


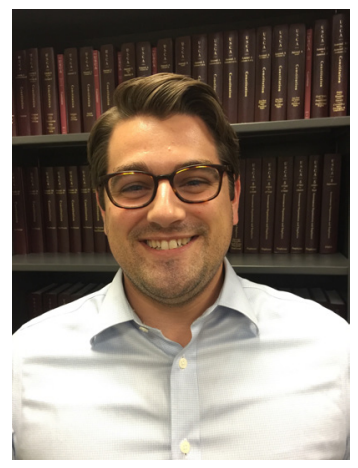

PHILIP KIBBEY is a Financial Disclosure Specialist at the U.S. Senate Select Committee on Ethics. He graduated from Cal Poly in 2010 with a degree in Political Science. 


\section{ALUMNI SPOTLIGHT Philip Kibbey}

A Political Science degree always seemed to be a perfect fit for Philip Kibbey, whose inmate interest in political theory led to the creation of an independent study within the department that synthesized political theory with pre-law. Philip credits his fascination with political theory partly as a direct link to the concentration's counterintuitive ability to remain practical both in the classroom and in a professional setting, in addition to its theoretical underpinnings. As Philip entered his career, his Political Science degree allowed him the confidence to handle any task asked of him.

After graduating in 2010, Philip pursued a life in Washington, D.C., where he landed a job as an assistant with the Senate Select Committee on Ethics, helping manage the Senate's public financial disclosure system. A job that began with completing administration tasks led to two and a half years working as a legal assistant, focusing on financial disclosure. After the European Finance Crisis in 2012, Philip became interested in finance, which led him to embark upon a position first as an analyst, and then as a Team Lead at Cambridge Associates, where he managed a team of six analysts helping clients with their finances and analyzing their hedge funds. Philip 
spent more than year at Cambridge Associates until the Ethics Committee asked him to return as a Financial Disclosure Specialist where he spends half of his job figuring out disclosures and working with senators. Meanwhile, the other half is spent creating software for an electronic financial disclosure system (eFD) for which he is the product owner. Philip recalls being asked to return to the Ethics Committee at such a young age as a significant accomplishment in his life. Currently, Philip spends his time corresponding with senators about their financial disclosure, continuing to develop the eFD application, assisting senators with their financial reports, and reviewing their amended financial reports.

Philip has always appreciated the practicality of the degree as it teaches students how to think, write effectively, and approach and execute problems. One of Philip's largest obstacles that he faced in his career occurred while he was helping a Cambridge Associates client with a very sophisticated and large financial report. Devotion to such a project meant logging long hours and working with large sums of money. This job meant having to learn advanced financial products concepts on the spot with the pressure to not make any mistakes. While a task like that could be quite daunting, Philip felt prepared to reach success through both his experience at Cal Poly and his political science classes.

Philip's career at the Ethics Committee developed through his enjoyment of constituent work, which led him to move to Washington, D.C., and apply for work in the Senate. For students who also have aspirations of working in government and even in following Philip's footsteps in the future, he advises to begin with internships. Internships are beneficial in helping to narrow down one's interests, which is why it is important to take them seriously. Fortunately, the government provides opportunities to discover internships and build networks. Even something as simple as talking to someone in government to see what they do can help with networking and illustrate the array of different options out there for career paths. Another excellent way to help secure a foot in the door of a government job is to work on a political campaign as they can also lead to permanent opportunities. Whichever path is chosen, student should remember to focus on being a strong worker as employers notice strong workers, especially in small offices.

For Cal Poly students as a whole, Philip would like to remind students that it is okay to be unsure of the future at this moment in their lives. Extensive 
pressure is placed on young people to know what they want to do, but it is okay to explore interests and change one's mind while one is young. Moreover, it is okay to try out different things, even if failure results. Follow all passions and embrace any fears of the unknown. This is the time to have fun, experience great things, meet people, make connections, try new adventures, and take advantage of different opportunities. Finally, enjoy life and enjoy the university while there because it will be missed after graduation. 


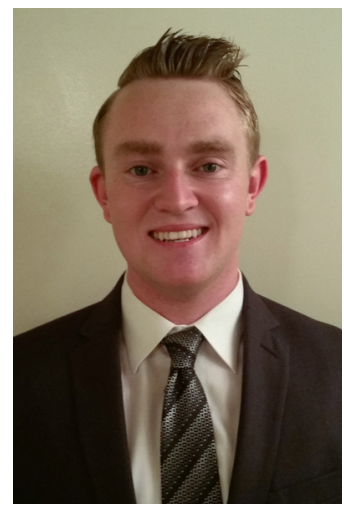

KYLE LIBBY is a third year Political Science major concentrating in Global Politics. His time at Cal Poly is spent participating in Model United Nations and working with the Institute of Advanced Technology and Public Policy on campus. Outside of campus, he volunteers at the food bank in downtown SLO and is also a licensed private pilot. After graduating, he hopes to get a job with the State Department. His inspiration for his paper developed from growing up in a law enforcement background, with his father being a detective with over 25 years' experience. This in combination with the recent media coverage focused on policing only deepened his interest in law enforcement. When Kyle looked more closely at other countries, he found many commonalities with emphasis on crime that deserved to be examined. 
COMPARATIVE POLICING: A BRIEF ANALYSIS OF CAUSAL FACTORS ON CRIME RATES AND LAW ENFORCEMENT IN CHINA, MEXICO, AND RUSSIA.

Kyle Libby

\begin{abstract}
Understanding how laws are adjudicated on a local level can be just as significant as understanding their origins. Crime rates and how they fluctuate relative to policing policies can reveal trends that can be traced back to social, economic, and cultural influences. When comparing China, Mexico, and Russia, we find that the similarities and differences can enlighten criminal behavior by contrasting statistics with national identity. When taken into the context of political development, effective policing policy could be extrapolated and identified.

\section{To Protect and Serve}

China, Mexico and Russia are constantly in the mainstream media, with evocative occurrences dominating contemporary discussion. In the United States, reports of police abuse fill the news cycle consistently. Regardless of how one may feel about each report individually, it is an undeniable symptom
\end{abstract}


that a problem exists with the culture on either side of the badge. Some think that the problem is institutional, but perhaps culture is the causal link to public safety instead. A comparative look at the police forces in other countries may shed some light. Mexico is constantly wracked by drug cartel violence and general unrest. Russia, for most intents and purposes, appears to have a relatively sound internal situation, yet an aggressive foreign strategy. China is thrusting itself onto the world stage, proclaiming its adequacy and controlling its domestic involvement. Policy implementation and adjudication at the lowest level, known as law enforcement, is clearly executed better in China than in Russia, which is then better than Mexico. Why is it that Mexico has experienced an institutional failure, while Russia has been able to maintain a relatively ethical hold on its police force, and China has been able to drastically reduce its crime? The answer lies in the political development of the states, namely how their power dynamics have changed recently. In Mexico, where bribes and exploitation of power are the norm, the development of the country has led to the same systemic corruption that is being fought in Russia. China uses corruption to its advantage. Mexico's system generates a higher per capita murder rate than Russia, as well as other key crime statistics. The ability to combat these criminal numbers lies within the strong authoritarian power of the contemporary Russian government. The Russians are attempting to mitigate the same problems that Mexico has encountered because they have the ability to reform their police force.

Some may argue that a country's ability to fight crime simply relies on a high police force per capita. After all, Mexico has 371.2 police officers per 100,000 people compared to Russia’s 522.0, as of 2013. In Mexico, there were 18.9 murders per 100,000 people in 2013 , compared to the 9.0 ratio of Russia. ${ }^{1}$ However, China possesses 120 police officers per 100,000 in 2007 , with a 1.2 ratio of the same metric. That same ratio was 2.0 in 2002, and 0.8 in 2012. ${ }^{2}$ An argument can be made that the problem of ineffective policing is not due to an inefficiency of resources, but that it is tied to the citizenry and to the development of the country. Even though these countries

\footnotetext{
${ }^{1}$ United Nations Office of Drugs and Crime. n.d. UNODC Statistics. Accessed November 2, 2015. https://data.unodc.org/.

2 Xinhua News Agency. 2007. China to Unify Police Identity Card from Jan. 1. January 1. Accessed November 30, 2015.
} 
have recently taken a departure from authoritarian governments, except for China, which has only just departed from an 'authoritarian' economy, the Russian social and political culture stands out as a more stable, law-abiding society compared to Mexico. Mexican political development is characterized by three concepts relevant to law enforcement: unstable change, a mix of interest articulation, and a weak society and weak state. Compared to Russian political development, which consists of a strong society and state and relatively strong interest articulation, (political changes in Russian history are somewhat stable, though not always) Mexico opens a window for self-interested parties to manipulate the system. Chinese political development is focused on a hierarchical structure of society, where one must 'keep his/her station'. Previously, Russian interest articulation was heavily “... regulated by the Communist Party, and there could be no open, active competition among political parties or interest groups for support..." This level of control is similar to how China's dual-rule system operates today. More recently, after perestroika and glasnost, as well as the fall of the Soviet Union, Russians have been more vocal about their ideologies, while still advocating for strong state control. Russian activists now believe "... [that] institutionalism of state power is a prerequisite for civil society development..." ${ }^{4}$ This allows for stronger participation in the political, and thus law making process. “... '[T] rust in the [national] political system' has the strongest influence on police attitudes in nine Latin American countries... with citizens... [not expressing confidence] in the less well-performing democrac[y]... of Mexico." ${ }^{5}$ Mexico is hindered by their lack of trust in a system that they cannot participate in fully. Why should they continue to vote, rally, and caucus if someone is going to sweep in by force and declare themselves the winner? "The...(in) formal rules of municipal governance [in Mexico] result in a lack of horizontal

\footnotetext{
${ }^{3}$ Remington, Thomas. n.d. Politics in Russia. 7. New York: Routledge. Accessed November 2, 2015 .

4 Taylor, Brian D. 2006. "Law Enforcement and Civil Society in Russia." Europe-Asia Studies 58 (2): 193-213. Accessed November 2, 2015.

5 Walker, Lee Demetrius, and Richard Waterman W. 2008. "Elections as Focusing Events: Explaining Attitudes toward the Police and the Government in Comparative Perspective." Law \& Society Review 42 (2): 337-366.
} 
accountability and reform continuity." ${ }^{6}$ This distrust has generated a caustic political outlook that cannot be sustained long-term.

China complicates this argument. Their authoritarian government is effectively accepted by the citizenry and social harmony is a core tenet of Chinese culture. While one may argue that having a strong central power is what keeps Chinese crime in check (crime meaning homicide rates in this case, obviously there is a broad range of crimes to be compared, but for the purpose of this paper, homicides will be used as a general indicator) asserting that it is both an increase in economic prowess and overall Chinese culture that maintains the low crime rates. The core beliefs of Confucianism necessitate a rule of morality and benevolence. In contrast to Russian and Mexican cultural history, which typically generates a more violent sociological response. While Chinese political history has hardly been pacifistic, Confucius created a now ingrained idea of a harmonious hierarchy and social unity that brings the Chinese people to behave more peacefully in their daily interaction with one another compared to what we see in Russia and Mexico. One is expected to live with the good of the society in mind, not in a self-serving way that commonly breeds crime. This leads to the argument that moral obligations could be the source of the differences in crime rates, not because of institutional guidance, but because of the public cultural psyche.

Corruption further hinders law enforcement in all areas. In Mexico the police officers on the ground are part of an institution of corruption, one that is focused on a self-centered mindset, not rule of law. This again stems from a mistrust in the government; that one should take any and all precautions to help oneself, because the political system is unreliable. While Russian police forces have historically used extortion and bribery in their enforcement, the economy of Russia has grown, allowing for economically supported change, as well as less incentive for the Russian officers to line their own pockets. In 2011, the Russian government overhauled its police force by firing 170,000 allegedly corrupt officers and raising the remaining officers' salaries. ${ }^{7}$ Aimed

\footnotetext{
${ }^{6}$ Pansters, Wil G. 2013. "Reviewed Work: Police Reform in Mexico. Informal Politics and the Challenge of Institutional Change by Daniel M. Sabet." European Review of Latin American and Caribbean Studies / Revista Europea de Estudios Latinoamericanos y del Caribe (Centrum voor Studie en Documentatie van Latijns Amerika (CEDLA)) 95: 128-131.

7 Russia Today. 2011. "Russia’s rebranded police initiated with major layoffs." Russia Today. March 1. Accessed November 2, 2015.
} 
at combating corruption, this reform was sweeping in its efforts to address the chronic enforcement issues identified by the government. This can only happen in a country with strong interest articulation. When the citizens are dissatisfied, they voice their opinions to elected officials or through their votes; which, in Russia's case, created a need for police reform. It is no coincidence that this is happening now in the post-Cold War era. The now strong, reorganized variant of Russian law enforcement is a sharp contrast from the decentralized and unregulated policing of Mexican law enforcement.

Yet, China has comparatively weak interest articulation compared to Russia, as the political agenda is tightly controlled by the Communist party. However, this grip on policy allows for effective change to be implemented quickly. As such, gun restrictions, regulations, and penal codes can adapt to a changing social landscape faster than it can in Russia and Mexico, which holds as another reason for low crime rates in China. To expand, China's flourishing economy causes Russia's to pale in comparison. The corruption that persists in Chinese governance and enforcement can allow economic growth to continue and the authoritarian hold on policy making to subsist. This can then cycle back into itself, as "the survival of a relatively strong state, in turn, can help to prevent the worst types of corruption from dominating society and market activities." 8 Policing to ensure social harmony is a key aspect of law enforcement in China. In 1991 (China stopped reporting police staffing in 1992), 34.9 percent of The People's Police were "social order police" and only 20.4 percent of officers were traffic or criminal police. ${ }^{9}$ While one could argue the semantics of the different types of police officers, it is clear that law enforcement is used just as much as a social tool as it is a peace one.

However, after Mexico's PRI party was removed from presidential power in 2000, how come Mexican democratization did not improve conditions in law enforcement? According to Daniel Sabet, the current political culture in Mexico creates "... a lack of horizontal accountability between the municipal president and the city council and... a lack of reform continuity across administrations... these two factors generate systematic obstacles to

\footnotetext{
${ }^{8}$ Sun, Yan. 1999. "Reform, State, and Corruption: Is Corruption Less Destructive in China than in Russia?" Comparative Politics 32 (1): 1-20.

9 Wong, Kam C. 2002. "Policing in the People's Republic of China: The Road to Reform in the 1990s." The British Journal of Criminology 42 (2): 281-316.
} 
institutional change." ${ }^{10}$ These accountability problems find their beginnings in the cultural disassociation that the Mexican people have with government, seated in a history full of revolution, dissent, and a strong caudillo system that exists throughout Latin America. While the Russians have had almost 30 years removed from their authoritative ruling party, the Mexicans are still dealing with the recent repercussions of a paradigm shift, as well as internal violence from organized crime. China, more authoritarian than either of the other two countries, has been capable of a tranquil domestic existence, thanks to the cultural upbringing of the population. Therefore, differences in policing originate from cultural and system wide conflicts, not simply numbers.

By connecting the examples explored, we can conclude that Mexico's police inefficacy is tied to the developmental shortcomings, identified as a lack of political involvement on the local level and little incentive to improve, thanks to the government's impotence. Furthermore, Russia's marked improvement in the field of law enforcement is linked to its increase in interest articulation, as well as its stronger horizontal accountability and civic involvement. Until the Mexican government and nation are able to address the blockages in the system by changing the culture of policing and aversion towards rule of law, organized crime will continue to flourish, with Mexico as its casualty. China has been successful in maintaining a safe social society, while contributing to the development of a civil one. Are the costs to democracy, despite political legitimacy worth it? For now, the Chinese people agree. Despite arguably similar ideologies in authoritarian governments, the political development of China, Russia, and Mexico has led to different outcomes in policy enforcement.

${ }^{10}$ Sabet, Daniel M. 2012. Police Reform in Mexico: Informal Politics and the Challenge of Institutional Change. Stanford: Stanford University Press. 
We must start first by thanking the Political Science department for its unconditional support of Paideia. Without you Paideia would not be possible.

Dr. Elizabeth Lowham, it has been your continuous advice that has contributed to the success of Paideia. You were always willing to sacrifice your time to help us achieve our goals and for that we are grateful.

Dr. Matthew Moore, thank you for continuing to allow us to use your Suggestions for Writing Papers as it has been vital during our editorial process.

Dr. Ning Zhang, thank you so much for all of your enthusiastic support. It was your ideas on marketing strategies and outreach to students that significantly contributed to the advancement of the journal.

Dr. Shelly Hurt, even on sabbatical you were still willing to help us with reaching out to student-authors and providing numerous paper recommendations and for that we are extremely grateful.

Dr. Jean Williams, we deeply appreciate how supportive you have continued to remain of Paideia. You have never failed in keeping us motivated with your outstanding words of encouragement.

A special thank you to all the Professors in the Political Science department for allowing our team members to come disturb your classes to speak about Paideia. It truly is a monumental outreach tool in gaining student participation in the journal.

Thank you to the co-founders of the journal, Joi Sullivan and Katie Magnus. It was your brilliant ideas and collaboration that transformed Paideia from a vision to a reality.

Ashley Stephens, words are not enough to describe how grateful we are to you for making the journal what it is today. Also, your constant willingness to answer any questions we had while constructing this year's volume made all the difference. 
We would also like to extend our deepest gratitude to Kristin Ventresca; you have so generously given your valuable time to helping us succeed.

Andrea Nash, we are so grateful for your gracious support of Paideia. You were always so quick in answering our many questions and helping us with production details.

Also, thank you Erik Salholm, for working so diligently with us as we crafted this year's Paideia website to be more engaging and advanced.

The Political Science Alumni Advisory Board, thank you for your continuous support and assistance with reaching out to alumni. Also, a thank you to Arthur Goldiner, for always being willing to meet and discuss the growth of the journal and answer any questions we had.

A congratulations to the student authors that have now become published authors. It truly was a pleasure to work with you all and we hope all the best for you in the future.

Featured Cal Poly Alumni, thank you for your willingness to dedicate your valuable time in sharing your experiences with us and allowing us to use you as motivation for current students advancing into their futures.

Thank you to Cal Poly's Graphic Communication department and Lorraine Donegan; who, year after year, has helped us in any way she could, including introducing us to Christina Barton. Christina, you have exceeded all expectations we hoped to have for our Graphic Designer. It was your flexibility and willingness to help us out with whatever necessary to get Paideia published that led to our success.

Lastly, a huge thank you to Dr. Anika Leithner, the faculty advisor for Paideia. We are so grateful for the amounts of time you have dedicated to helping us achieve our goals. Especially during times of stress, it was your patient guidance that was able to move us smoothly forward. 
